Prepared in cooperation with the Cities of Auburn, Milton, Puyallup, Sumner, and Tacoma; Pierce Conservation District; Washington State Department of Health; Cascade Water Alliance; Lakehaven Utility District; Summit Water \& Supply Company; Mt. View-Edgewood Water Company; and The Russell Family Foundation

\title{
Hydrogeologic Framework, Groundwater Movement, and Water Budget in the Puyallup River Watershed and Vicinity, Pierce and King Counties, Washington
}

Scientific Investigations Report $2015-5068$ 
Cover: View of Puyallup River from the Calistoga Road bridge

looking upstream, with Mount Rainier in the distance, Orting, Washington.

(Photograph taken by Jonathan Czuba, U.S. Geological Survey, October 27, 2010.) 


\section{Hydrogeologic Framework, Groundwater Movement, and Water Budget in the Puyallup River Watershed and Vicinity, Pierce and King Counties, Washington}

By Wendy B. Welch, Kenneth H. Johnson, Mark E. Savoca, Ron C. Lane, Elisabeth T. Fasser, Andrew S. Gendaszek, Cameron Marshall, Burt G. Clothier, and Eric N. Knoedler

Prepared in cooperation with the Cities of Auburn, Milton, Puyallup, Sumner, and Tacoma; Pierce Conservation District; Washington State Department of Health; Cascade Water Alliance; Lakehaven Utility District; Summit Water \& Supply Company; Mt. View-Edgewood Water Company; and The Russell Family Foundation

Scientific Investigations Report 2015-5068 


\title{
U.S. Department of the Interior SALLY JEWELL, Secretary
}

\section{U.S. Geological Survey \\ Suzette M. Kimball, Acting Director}

\author{
U.S. Geological Survey, Reston, Virginia: 2015
}

For more information on the USGS - the Federal source for science about the Earth, its natural and living resources, natural hazards, and the environment—visit http://www.usgs.gov or call 1-888-ASK-USGS.

For an overview of USGS information products, including maps, imagery, and publications, visit http://www.usgs.gov/pubprod/.

Any use of trade, firm, or product names is for descriptive purposes only and does not imply endorsement by the U.S. Government.

Although this information product, for the most part, is in the public domain, it also may contain copyrighted materials as noted in the text. Permission to reproduce copyrighted items must be secured from the copyright owner.

Suggested citation:

Welch, W.B., Johnson, K.H., Savoca, M.E., Lane, R.C., Fasser, E.T., Gendaszek, A.S., Marshall, C., Clothier, B.G., and Knoedler, E.N., 2015, Hydrogeologic framework, groundwater movement, and water budget in the Puyallup River Watershed and vicinity, Pierce and King Counties, Washington: U.S. Geological Survey Scientific Investigations Report 2015-5068, 54 p., 4 pls., http://dx.doi.org/10.3133/sir20155068.

ISSN 2328-0328 (online) 


\section{Contents}

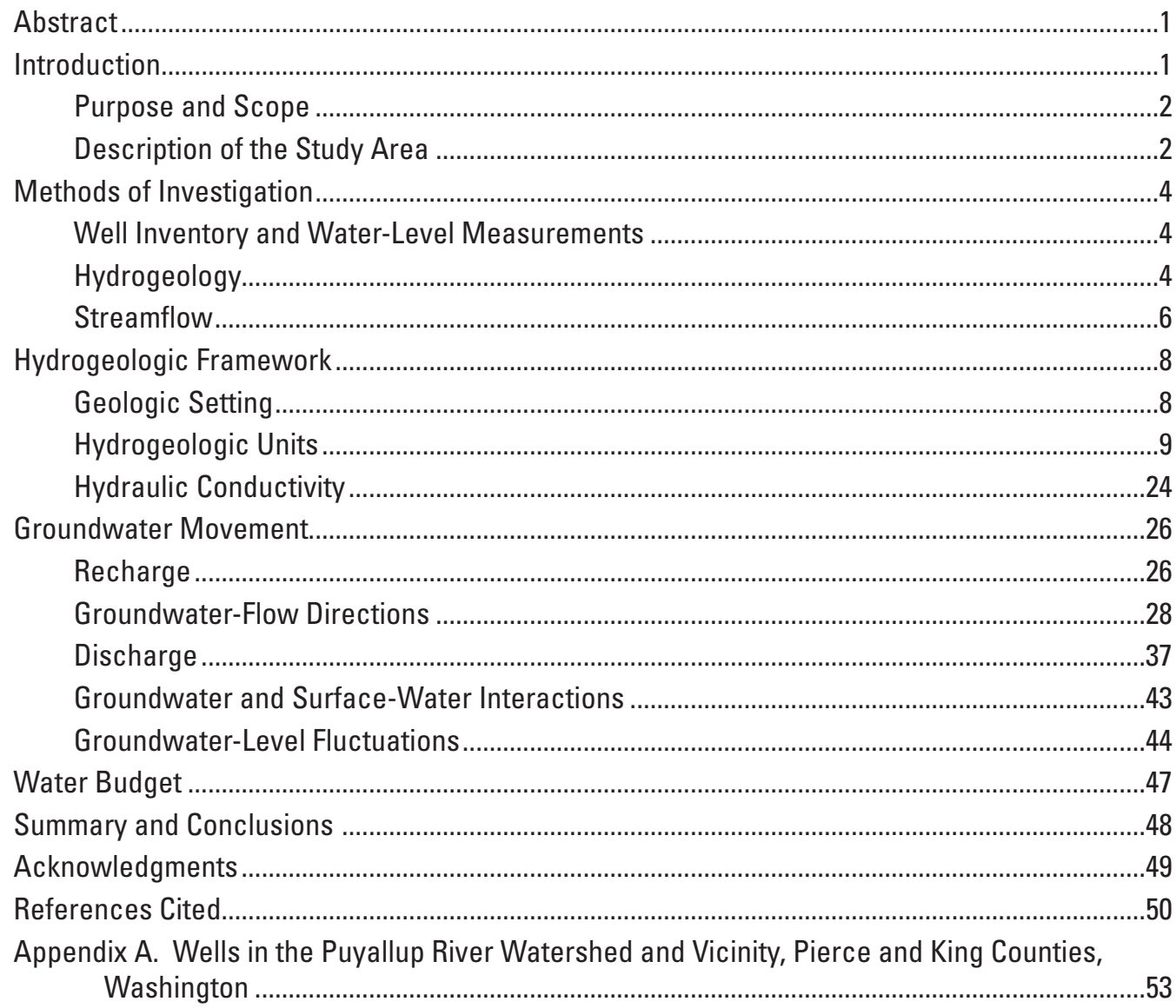

\section{Plates}

[Available for download as a layered PDF at http://pubs.usgs.gov/sir/2015/5068/]

1. Map showing locations of selected wells in the Puyallup River Watershed and vicinity, Pierce and King Counties, Washington

2. Map showing surficial hydrogeology, cross section traces, and locations of selected wells in the Puyallup River Watershed and vicinity, Pierce and King Counties, Washington

3. Hydrogeologic sections, Puyallup River Watershed and vicinity, Pierce and King Counties, Washington

4. Map showing location of surface-water discharge sites in the Puyallup River Watershed and vicinity, Pierce and King Counties, Washington 


\section{Figures}

1. Map showing location of Puyallup River Watershed and vicinity, Washington

2. Graphs showing residuals between hydrogeologic unit correlation altitudes and altitudes of interpolated digital hydrogeologic surfaces, Puyallup River Watershed and vicinity, Washington

3. Map showing extent and thickness of AL1 upper alluvial aquifer in Puyallup River Watershed and vicinity, Washington...

4. Map showing extent and thickness of MFL confining unit in Puyallup River Watershed and vicinity, Washington.

5. Map showing extent and thickness of AL2 lower alluvial aquifer in Puyallup River Watershed and vicinity, Washington.

6. Map showing extent and thickness of A1 aquifer in Puyallup River Watershed and vicinity, Washington

7. Map showing extent and thickness of $A 2$ confining unit in Puyallup River Watershed and vicinity, Washington.

8. Map showing extent and thickness of A3 aquifer in Puyallup River Watershed and vicinity, Washington.....

9. Map showing extent and thickness of B confining unit in Puyallup River Watershed and vicinity, Washington.

10. Map showing extent and thickness of $C$ aquifer in Puyallup River Watershed and vicinity, Washington

11. Map showing extent and thickness of $D$ confining unit in Puyallup River Watershed and vicinity, Washington.

12. Map showing extent and thickness of $E$ aquifer in Puyallup River Watershed and vicinity, Washington

13. Map showing extent and thickness of $F$ confining unit in Puyallup River Watershed and vicinity, Washington.

14. Map showing extent and thickness of $\mathrm{G}$ undifferentiated deposits in Puyallup River Watershed and vicinity, Washington ...

15. Map showing average annual precipitation, canopy cover, and impervious surface across the Puyallup River Watershed and vicinity, Washington, January 2011December 2012.

16. Graph showing precipitation-recharge relations used in this study, Puyallup River Watershed and vicinity, Washington.

17. Map showing distribution of average annual groundwater recharge from precipitation in Puyallup River Watershed and vicinity, Washington, January 2011December 2012.

18. Map showing water-level altitudes and direction of groundwater flow in AL1 upper alluvial aquifer, Puyallup River Watershed and vicinity, Washington, March 2011-March 2013

19. Map showing water-level altitudes and direction of groundwater flow in AL2 lower alluvial aquifer, Puyallup River Watershed and vicinity, Washington, March 2011-March 2013.

20. Map showing water-level altitudes and direction of groundwater flow in A1 aquifer, Puyallup River Watershed and vicinity, Washington, March 2011-March 2013... 32

21. Map showing water-level altitudes and direction of groundwater flow in A3 aquifer, Puyallup River Watershed and vicinity, Washington, March 2011-March 2013. 


\section{Figures-Continued}

22. Map showing water-level altitudes and direction of groundwater flow in $\mathrm{C}$ aquifer, Puyallup River Watershed and vicinity, Washington, March 2011-March 2013.............34

23. Map showing water-level altitudes and direction of groundwater flow in $\mathrm{E}$ aquifer, Puyallup River Watershed and vicinity, Washington, March 2011-March 2013.............35

24. Map showing water-level altitudes and direction of groundwater flow in $\mathrm{G}$ undifferentiated deposits, Puyallup River Watershed and vicinity, Washington, March 2011-March 2013.

25. Graph showing mean monthly streamflow at U.S. Geological Survey streamflow-gaging stations for the Puyallup, White, and Green Rivers, Puyallup River Watershed and vicinity, Washington

26. Graph showing daily streamflow for U.S. Geological Survey streamflow-gaging stations on the Puyallup, White, and Green Rivers, Puyallup River Watershed and vicinity, Washington, October 12-22, 2011

27. Graph showing daily streamflow for U.S. Geological Survey streamflow-gaging stations on the Puyallup, White, and Green Rivers, Puyallup River Watershed and vicinity, Washington, October 5-15, 2012 .

28. Hydrographs of water levels in well 20N/06E-18E01, stream stage at U.S. Geological Survey streamflow-gaging station on Boise Creek, and precipitation at Auburn, Puyallup River Watershed and vicinity, Washington, August 2011-January 2013..........46

29. Hydrographs of water levels in well 19N05E-36N01, stream stage at U.S.Geological Survey streamflow-gaging station on the Puyallup River, and precipitation at McMillin Reservoir, Puyallup River Watershed and vicinity,Washington, August 2011-January 2013

\section{Tables}

1. Hydrogeologic units defined in this study and correlation with geologic and hydrostratigraphic units from previous investigations..

2. Statistics for the interpolated digital hydrogeologic surfaces ..........................................

3. Summary of hydraulic conductivity values estimated from specific-capacity data and aquifers tests, by hydrogeologic unit, Puyallup River Watershed and vicinity, Washington.

4. Estimates of groundwater discharge to streams (baseflow) draining the Puyallup River Watershed and vicinity, Washington, October 2011 and October 2012...

5. Synoptic streamflow measurements and estimates of gains and losses in the Puyallup River Watershed and vicinity, Washington, October 2011 and October 2012

6. Estimated groundwater withdrawals from wells in 2012, Puyallup River Watershed, Washington.

7. Summary of groundwater-level fluctuations and well depths by hydrogeologic unit, Puyallup River Watershed, Washington, March 2011 through March 2013

8. Estimated annual water budget for Puyallup River Watershed and vicinity, Washington, January 1, 2011 through December 31, 2012 


\section{Conversion Factors}

Inch/Pound to International System of Units

\begin{tabular}{|c|c|c|}
\hline Multiply & By & To obtain \\
\hline \multicolumn{3}{|c|}{ Length } \\
\hline inch (in.) & 2.54 & centimeter (cm) \\
\hline inch (in.) & 25.4 & millimeter (mm) \\
\hline foot $(\mathrm{ft})$ & 0.3048 & meter (m) \\
\hline \multicolumn{3}{|c|}{ Area } \\
\hline square mile $\left(\mathrm{mi}^{2}\right)$ & 259.0 & hectare (ha) \\
\hline square mile $\left(\mathrm{mi}^{2}\right)$ & 2.590 & square kilometer $\left(\mathrm{km}^{2}\right)$ \\
\hline \multicolumn{3}{|c|}{ Volume } \\
\hline gallon (gal) & 3.785 & liter (L) \\
\hline gallon (gal) & 0.003785 & cubic meter $\left(\mathrm{m}^{3}\right)$ \\
\hline gallon (gal) & 3.785 & cubic decimeter $\left(\mathrm{dm}^{3}\right)$ \\
\hline acre-foot (acre-ft) & 1,233 & cubic meter $\left(\mathrm{m}^{3}\right)$ \\
\hline acre-foot (acre-ft) & 0.001233 & cubic hectometer $\left(\mathrm{hm}^{3}\right)$ \\
\hline \multicolumn{3}{|c|}{ Flow rate } \\
\hline acre-foot per year (acre-ft/yr) & 1,233 & cubic meter per year (m³/yr) \\
\hline acre-foot per year (acre-ft/yr) & 0.001233 & cubic hectometer per year $\left(\mathrm{hm}^{3} / \mathrm{yr}\right)$ \\
\hline foot per day $(\mathrm{ft} / \mathrm{d})$ & 0.3048 & meter per day $(\mathrm{m} / \mathrm{d})$ \\
\hline cubic foot per second $\left(\mathrm{ft}^{3} / \mathrm{s}\right)$ & 0.02832 & cubic meter per second $\left(\mathrm{m}^{3} / \mathrm{s}\right)$ \\
\hline $\begin{array}{l}\text { cubic foot per second per mile } \\
{\left[\left(\mathrm{ft}^{3} / \mathrm{s}\right) / \mathrm{mi}\right]}\end{array}$ & 0.01760 & $\begin{array}{l}\text { cubic meter per second per } \\
\text { kilometer }\left[\left(\mathrm{m}^{3} / \mathrm{s}\right) / \mathrm{km}\right]\end{array}$ \\
\hline $\begin{array}{l}\text { cubic foot per second per square } \\
\text { mile }\left[\left(\mathrm{ft}^{3} / \mathrm{s}\right) / \mathrm{mi}^{2}\right]\end{array}$ & 0.01093 & $\begin{array}{l}\text { cubic meter per second per square } \\
\text { kilometer }\left[\left(\mathrm{m}^{3} / \mathrm{s}\right) / \mathrm{km}^{2}\right]\end{array}$ \\
\hline cubic foot per day $\left(\mathrm{ft}^{3} / \mathrm{d}\right)$ & 0.02832 & cubic meter per day $\left(\mathrm{m}^{3} / \mathrm{d}\right)$ \\
\hline gallon per day (gal/d) & 0.003785 & cubic meter per day (m³/d) \\
\hline inch per year (in/yr) & 25.4 & millimeter per year (mm/yr) \\
\hline \multicolumn{3}{|c|}{ Hydraulic conductivity } \\
\hline foot per day (ft/d) & 0.3048 & meter per day (m/d) \\
\hline
\end{tabular}

\section{Supplemental Information}

Temperature in degrees Celsius $\left({ }^{\circ} \mathrm{C}\right)$ may be converted to degrees Fahrenheit $\left({ }^{\circ} \mathrm{F}\right)$ as ${ }^{\circ} \mathrm{F}=\left(1.8 \times{ }^{\circ} \mathrm{C}\right)+32$.

Temperature in degrees Fahrenheit $\left({ }^{\circ} \mathrm{F}\right)$ may be converted to degrees Celsius $\left({ }^{\circ} \mathrm{C}\right)$ as ${ }^{\circ} \mathrm{C}=\left({ }^{\circ} \mathrm{F}-32\right) / 1.8$.

\section{Datums}

Vertical coordinate information is referenced to the North American Vertical Datum of 1988 (NAVD 88), referred to in this report as "sea level."

Horizontal coordinate information is referenced to the North American Datum of 1983 (NAD 83).

Altitude, as used in this report, refers to distance above or below sea level. 


\section{Well-Numbering System}

Wells in the State of Washington are assigned a local well number that identifies each well based on its location in a township, range, section, and 40 -acre tract. For example, local well number 20N/04E-14B01 indicates that the well is in township 20 north of the Willamette Base Line, and range 4 east of the Willamette Meridian. The numbers immediately following the hyphen indicate the section (14) in the township. Most range-townships in Washington are divided into 36 equal sections of $1 \mathrm{mi}^{2}$ (640 acres) numbered from 1-36. However, the Washington Territory Donation Land Claims of 1852-55 predate the Public Lands Survey and appear on maps as irregularly sized and shaped sections with assigned section numbers greater than 36. The letter following the section (B) gives the 40 -acre tract of the section. The two-digit sequence number (01) following the letter is used to distinguish individual wells in the same 40 -acre tract. A " $D$ " following the sequence number indicates a well that has been deepened. In the plates of this report, wells are identified using only the section and 40 -acre tract, such as 14B01; the township and range are shown on the map borders.

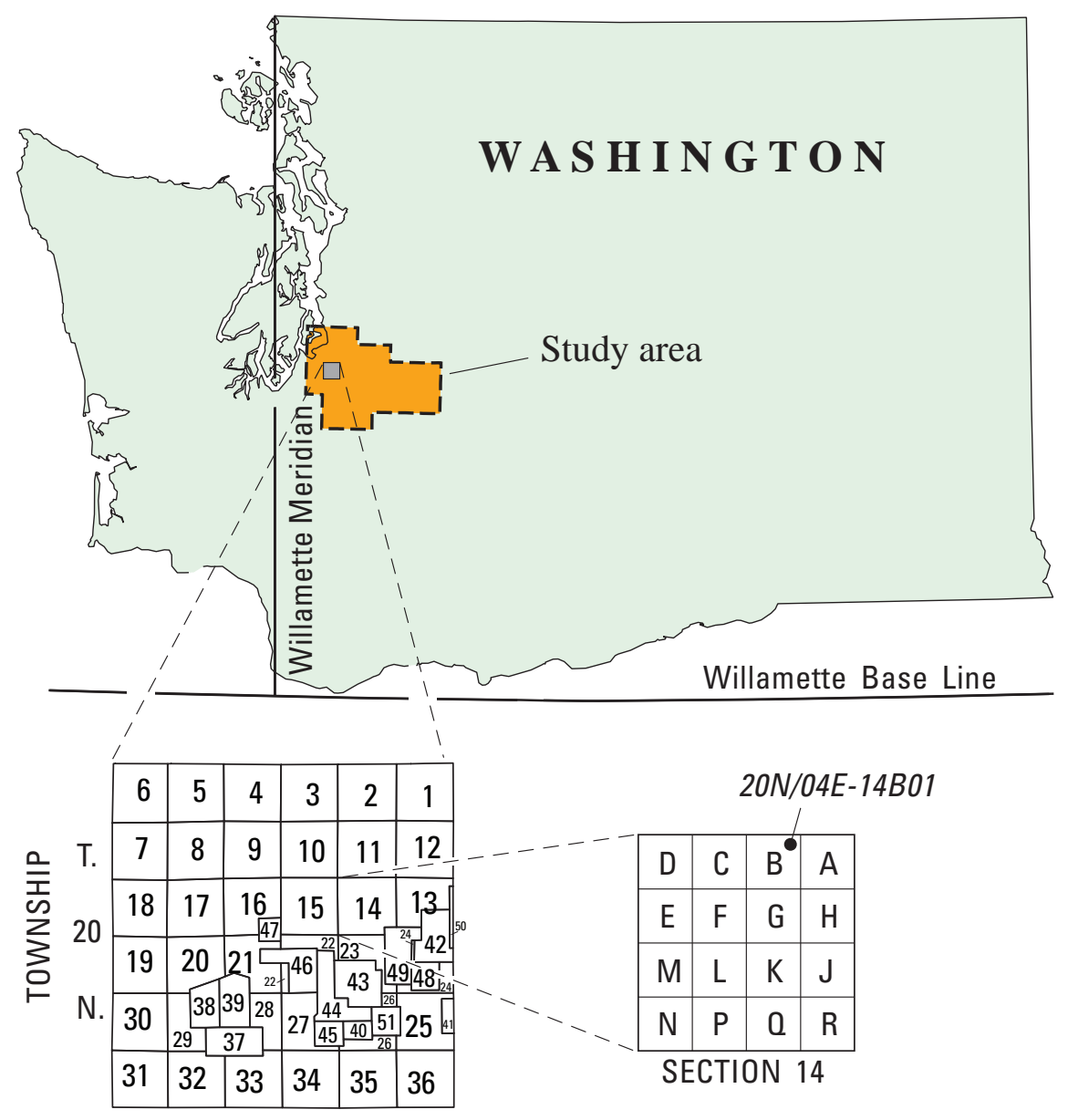

R. $04 \mathrm{E}$.

\section{RANGE}

Diagram showing well-numbering system used in Washington. 



\title{
Hydrogeologic Framework, Groundwater Movement, and Water Budget in the Puyallup River Watershed and Vicinity, Pierce and King Counties, Washington
}

\author{
By Wendy B. Welch', Kenneth H. Johnson', Mark E. Savoca', Ron C. Lane ${ }^{1}$, Elisabeth T. Fasser ${ }^{1}$, Andrew S. \\ Gendaszek', Cameron Marshall', Burt G. Clothier ${ }^{2}$, and Eric N. Knoedler ${ }^{3}$
}

\section{Abstract}

This report presents information used to characterize the groundwater-flow system in the Puyallup River Watershed and vicinity, and includes descriptions of the geology and hydrogeologic framework; groundwater recharge and discharge; groundwater levels and flow directions; seasonal groundwater level fluctuations; interactions between aquifers and the surface-water system; and a water budget. The study area covers about 1,220 square miles in northern Pierce and southern King Counties, Washington; extends north to the Green River and Auburn Valley and southwest to the Puyallup River and adjacent uplands; and is bounded on the south and east by foothills of the Cascade Range and on the west by Puget Sound. The area is underlain by a northwest-thickening sequence of unconsolidated glacial and interglacial deposits, which overlie sedimentary and volcanic bedrock units that crop out in the foothills along the southern and eastern margin of the study area. Geologic units were grouped into 13 hydrogeologic units consisting of aquifers, confining units, and an underlying bedrock unit. A surficial hydrogeologic unit map was developed and used with well information from 1,012 drillers' logs to construct 8 hydrogeologic sections, and unit extent and thickness maps.

Groundwater in unconsolidated glacial and interglacial aquifers generally flows to the northwest towards Puget Sound, and to the north and northeast towards the Puyallup River, White River, and Green River valleys. These generalized flow patterns are complicated by the presence of low permeability confining units and bedrock that separate discontinuous bodies of aquifer material and act as local groundwater-flow barriers. Water levels in wells completed in the unconsolidated hydrogeologic units show seasonal variations ranging from less than 1 to about 32 feet during the monitoring period (March 2011-March 2013).

\footnotetext{
${ }^{1}$ U.S. Geological Survey.

${ }^{2}$ Robinson Noble, Inc.

${ }^{3}$ University of Washington.
}

Synoptic streamflow measurements made in October 2011 and October 2012 indicated a total groundwater discharge to streams in the water-budget area (520 square miles located within the larger study area) of at least 349,000 and 280,000 acre-feet per year, respectively. Annual groundwater discharge to streams likely exceeds these values because streamflow measurements were made during the dry, late-summer and early-autumn period when groundwater levels typically are at annual lows. Most stream reaches in the study area either gain flow from groundwater discharge or exhibit near-neutral conditions with no substantial gain or loss of flow. Groundwater discharge occurs at numerous springs in the area; the total reported discharge of springs in the area is approximately 80,300 acre-feet per year.

The water-budget area received about 1,428,000 acre-feet or about 52 inches of precipitation per year (January 1, 2011, to December 31, 2012). About 41 percent of precipitation enters the groundwater system as recharge. Seven percent of this recharge is withdrawn from wells and the remainder leaves the groundwater system as discharge to rivers, discharge to springs, or submarine discharge to Puget Sound, or exits the study area through subsurface flow in the Green River valley.

\section{Introduction}

Groundwater is an important resource for domestic, commercial, and industrial usage in the Puyallup River Watershed (PRW), and groundwater discharge helps maintain late-summer and early-autumn streamflow (baseflow) in many area streams. Consequently, as the population grows, and commercial and industrial activity increase, so does the demand for groundwater. However, the quantity of usable groundwater, the potential effects of future natural conditions and anthropogenic activities on groundwater resources, and the potential effects of groundwater withdrawals on streamflow, are not well understood in some areas of the watershed. Additional information is required to help ensure the long-term sustainability of the area's groundwater and 
surface-water resources. In January 2011, the U.S. Geological Survey (USGS) in cooperation with State and local project-funding partners ${ }^{4}$ began a project to characterize the groundwater-flow system in the PRW and vicinity. A second phase of this project will integrate this and other information into a numerical groundwater-flow model to contribute to an improved understanding of water resources in the PRW.

\section{Purpose and Scope}

This report presents information used to characterize the groundwater-flow system in the PRW and vicinity. The report includes descriptions of the geology and hydrogeologic framework of the area, groundwater recharge and discharge, groundwater levels and flow directions, seasonal groundwater-level fluctuations, interactions between aquifers and the surface-water system, and a water budget to provide initial estimates of groundwater recharge, groundwater discharge to streams and springs, and withdrawals from wells to be used in the construction of a numerical groundwater-flow model.

\section{Description of the Study Area}

The study area covers about $1,220 \mathrm{mi}^{2}$ in northern Pierce and southern King Counties, Washington (fig. 1), and initially was selected to include major hydrologic features that could be used as regional model boundaries during the second phase of this project. The study area defines the region of groundwater and surface-water data collection, and coincides with the area in which the hydrogeologic framework was developed. The study area extends north to the Green River, Auburn Valley, and adjacent uplands, southwest to the Puyallup River and adjacent uplands; and is bounded on the south and east by foothills of the Cascade Range, and to the west by Puget Sound.

The study area is underlain by a northwest-thickening sequence of unconsolidated glacial (till and outwash) and interglacial (fluvial, lacustrine, and mudflow) deposits. Sedimentary and volcanic bedrock units underlie the unconsolidated deposits and crop out in the foothills along the southern and eastern margins of the study area. Land-surface altitude in the study area ranges from sea level along the Puget Sound coast to near 6,400 ft in the southeastern foothills.

The northwest-flowing Puyallup River occupies a large, relatively flat alluvial valley, and together with its major tributaries (the Carbon and White Rivers) drains a broad upland region that covers most of the study area. Tributaries to

\footnotetext{
${ }^{4}$ The Cities of Auburn, Milton, Puyallup, Sumner, and Tacoma, Pierce Conservation District, Washington State Department of Health, Cascade Water Alliance, Lakehaven Utility District, Summit Water \& Supply Company, Mt. View-Edgewood Water Company, and The Russell Family Foundation.
}

major rivers in the central part of the study area include Boise, South Prairie, Wilkeson, and Voight Creeks. The Clearwater and Greenwater Rivers, and Huckleberry Creek flow into the White River in the eastern part of the study area; and Swan, Clear, Clarks, and Hylebos Creeks join the Puyallup River near its mouth in the western part of the study area. The Green River flows to the west, along the northern margin of the study area, before turning to the north upon entering the Auburn Valley where it is joined by Big Soos Creek. The White River historically discharged to the north as a tributary to the Green River until it was modified to flow south to the Puyallup River early in the 20th century. Several streams drain upland areas along the northwestern part of the study area including Des Moines, Massey, McSorley, Lakota, and Cold Creeks. Perennial streamflow conditions are present in the Puyallup River and its major tributaries, all of which receive flow from melting snow and glacial ice in addition to groundwater discharge and overland flow from precipitation. Intermittent and ephemeral flow conditions are common in many smaller tributary stream reaches, especially during the summer months. The Green River is regulated at Howard Hanson Dam, the Puyallup River has a hydroelectric diversion at Electron, and the Cascade Water Alliance diverts water from the White River into Lake Tapps. Numerous springs are present throughout the study area, and contribute to late-summer baseflow to streams and year-round groundwater discharge to Puget Sound along shoreline bluffs. Major lakes in the study area include Lake Sawyer, Lake Tapps, Lake Spanaway, and Kapowsin Lake. These lakes have formed under a variety of processes including glaciation (kettle), mudflow deposition (dam), and man-made reservoirs; and several lakes in the study area generally reflect water levels in the shallow groundwater-flow system. Outflows from Kapowsin Lake are unregulated. Lake Sawyer and Spanaway Lake have fixed-elevation controlled outfalls, and outflows from Lake Tapps are actively regulated. Many small lakes in the area are associated with poorly drained wetland areas typically formed on glacial till deposits.

The study area has a temperate marine climate with warm, dry summers, and cool, wet winters. Temperatures are moderated by the Pacific Ocean and Puget Sound. The ocean provides an abundant supply of moisture for winter storms that typically approach the area from the southwest. Mean annual precipitation (average annual precipitation for 1981-2010) is 39.2 in. at Tacoma and 47.8 in. at Buckley (National Oceanic and Atmospheric Administration, 2013). The distribution of precipitation varies throughout the year. Summers (June-August) typically are dry with a mean total precipitation of $3.1 \mathrm{in}$. at Tacoma and 5.7 in. at Buckley. Winters (December-February) are wetter than summers with a mean total precipitation of 15.3 in. at Tacoma and 15.5 in. at Buckley. Mean monthly temperature (average monthly temperature for 1981-2010) at these locations ranges from about $41^{\circ} \mathrm{F}$ in December to about $66^{\circ} \mathrm{F}$ in August (National Oceanic and Atmospheric Administration, 2013). 


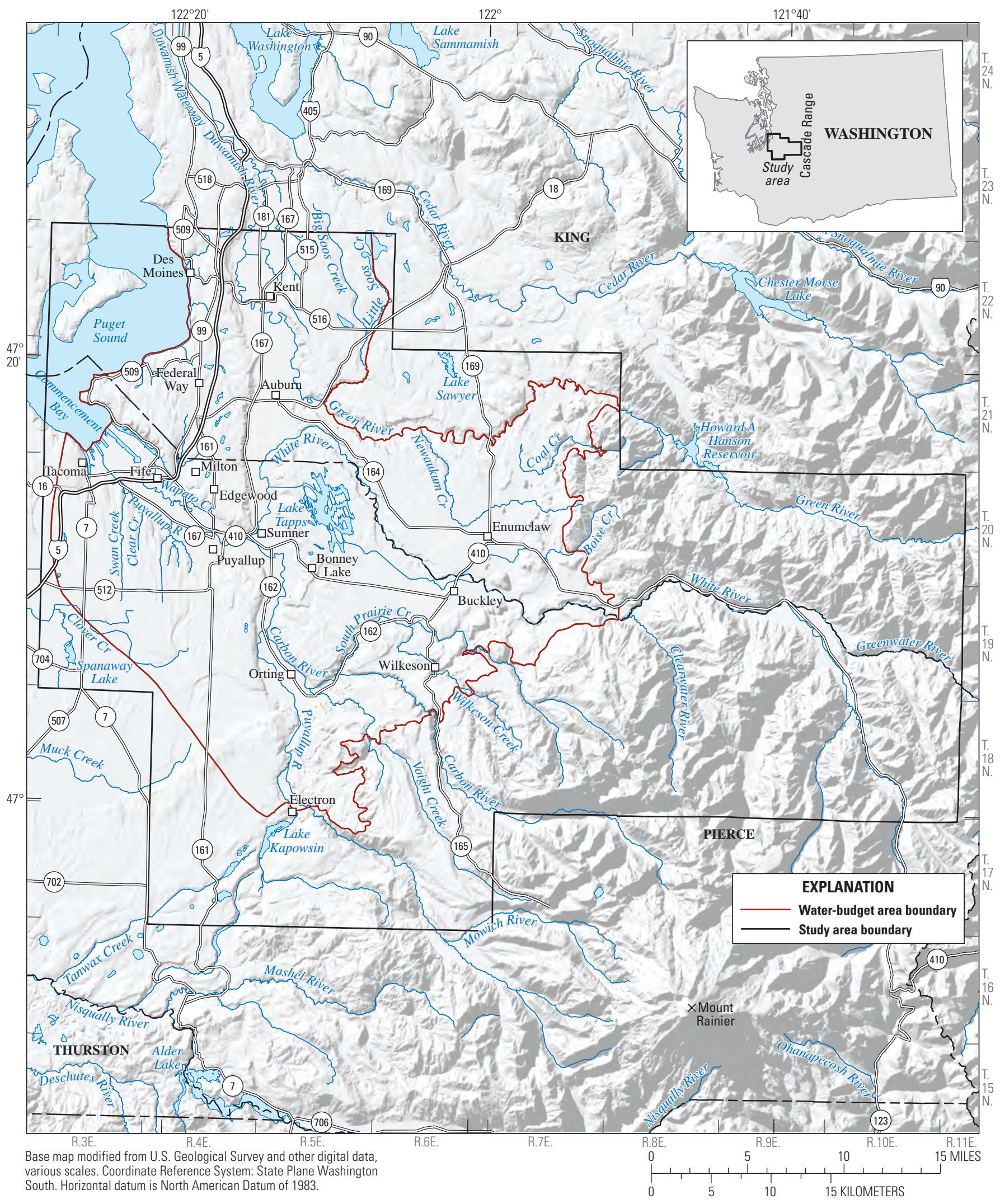

Figure 1. Location of Puyallup River Watershed and vicinity, Washington. 
The water-budget area $\left(520 \mathrm{mi}^{2}\right)$ is located within the larger study area (fig. 1), and was delineated after completion of the hydrogeologic framework to more closely approximate the area to be used in development of the numerical flow model of the PRW and vicinity. The water-budget area is bounded to the northeast by the Green River and the southern part of Big Soos Creek, extends south and east to foothills of the Cascade Range (approximate extent of most waterbearing hydrogeologic units), and to the west by Puget Sound. The southwestern and northern margins of the water-budget area generally coincide with groundwater divides previously delineated by Savoca and others (2010) and Woodward and others (1995), respectively. A previously developed groundwater model (Johnson and others, 2011) that includes upland areas adjacent to the Puyallup River valley also simulates a groundwater divide along the southwestern margin of the water-budget area, and this previously developed model may be used during the second phase of this project to constrain hydraulic conditions along the southwestern boundary of the PRW model. The water-budget area includes all groundwater-level and most streamflow-data collection sites. In this report, the water-budget area defines the region in which water-budget components were estimated, and excludes areas where low permeability bedrock units are exposed at land surface.

\section{Methods of Investigation}

Methods used to compile and analyze information for the characterization of the groundwater-flow system in the study area are described in this section. Methods used to determine groundwater movement and estimate water-budget components are included with the respective sections later in this report.

\section{Well Inventory and Water-Level Measurements}

The characterization of the groundwater-flow system was based on the analysis of spatially distributed information about groundwater levels and the physical and hydraulic properties of the geologic units encountered during well construction. Spatial information was obtained through the measurement of water levels in wells, and the compilation and analysis of hydrogeologic descriptions and well tests from well drillers' logs. Well records that document the drilling (drillers' log description of borehole lithology), construction, and, sometimes, hydraulic testing of wells were compiled from USGS and Washington State Department of Ecology (WADOE) databases to identify potential wells to be used in this study. Candidate wells were selected for field inventory based on the location and depth of the well, and the availability of a complete well record with drillers' log. Well records with insufficient well location and construction information or incomplete or poorly constrained drillers' logs were not considered for field inventory and were not used in this study. The goal of the inventory was to obtain an even distribution of wells throughout the study area. However, this was not possible for the entire study area because of a lack of wells both in less populated rural areas and in some areas within larger city limits (for example, Tacoma). During the USGS field inventory (January-February 2011), permission for access was obtained, and synoptic waterlevel measurements were made in 201 wells (appendix A, pl. 1). Water levels were manually measured on a monthly basis from March 2011 through March 2013 in 130 of the inventoried wells (pl. 1), and continuous water-level recorders were installed in 4 of these monthly monitoring wells. (appendix A, pl. 1).

All water-level measurements were made by USGS personnel in accordance with USGS standard techniques (Kozar and Kahle, 2013). Water level, reported as depth-towater below land surface, was measured using a calibrated electric tape or graduated steel tape, both with a stated accuracy of $0.01 \mathrm{ft}$. Although there is the potential for error in depth-to-water measurements associated with borehole deviation in sub-vertical wells, the frequency of significant deviation is expected to be low. Latitude and longitude locations were determined for each well using a Global Positioning System (GPS) receiver with a horizontal accuracy of 0.1 second (about $10 \mathrm{ft}$ ). Land-surface altitude for each well was obtained from a digital elevation model with 10-m square cells using the latitude and longitude of each well. Water-level altitudes were determined by subtracting the measured depthto-water below land surface from the digital elevation model derived land-surface altitude at each well. Monthly water-level data for an additional 51 wells were provided by various water purveyors and local stakeholders (appendix A, pl. 1).

The spatial distribution of hydrogeologic data compiled solely from inventoried wells was insufficient to accurately characterize the spatial variability of hydrogeologic units across the study area. Therefore, more than 750 additional wells with available drillers' logs were analyzed during this study to better represent the hydrogeologic framework in areas where inventory wells were lacking (pl. 1). Well locations and drillers' logs for these additional wells were obtained from the records of the WADOE, local public water supply systems, environmental consulting firms, and the USGS. Well information collected during the field inventory, the monthly monitoring network, and during the construction of the hydrogeologic framework were entered into the USGS National Water Information System (NWIS) database (http:// waterdata.usgs.gov/nwis).

\section{Hydrogeology}

The hydrogeologic units in the Puyallup River Watershed and vicinity were defined using a combination of geologic data including existing surficial geologic maps, well records with drillers' logs available from the WADOE, and previous 
investigations by Brown and Caldwell (1985), Dragovich and others (1994), Woodward and others (1995), and Robinson \& Noble, Inc., and others (2003).

The surficial hydrogeologic map for the study area (pl. 2; scale 1:85,000) was produced by merging 1:100,000 scale surficial geologic maps (Schasse, 1987; Walsh, 1987; Tabor and others, 2000) with multiple 1:24,000 surficial geologic maps (Booth and others, 2004; Booth and Waldron, 2004;K.G. Troost, U.S. Geological Survey, written commun., 2008). More than 80 geologic units delineated on these source maps were grouped into 13 hydrogeologic units based on similarities in lithology (grain size and sorting), hydrologic characteristics, and relative stratigraphic position (table 1).

Table 1. Hydrogeologic units defined in this study and correlation with geologic and hydrostratigraphic units from previous investigations.

\begin{tabular}{|c|c|c|c|c|c|c|}
\hline .믄 & 등 & $\begin{array}{l}\text { Hydrogeologic } \\
\text { units defined } \\
\text { in this study }\end{array}$ & $\begin{array}{c}\text { Geologic units } \\
\text { (from K.G. Troost, } \\
\text { U.S. Geological } \\
\text { Survey, written } \\
\text { commun., 2008) }\end{array}$ & $\begin{array}{l}\text { Geologic units } \\
\text { in Schasse (1987) } \\
\text { and Walsh (1987) }\end{array}$ & $\begin{array}{l}\text { Hydrostratigraphic units } \\
\text { in Robinson \& Noble, } \\
\text { Inc., and others (2003) }\end{array}$ & $\begin{array}{l}\text { Stratigraphic } \\
\text { units }\end{array}$ \\
\hline \multirow{12}{*}{ 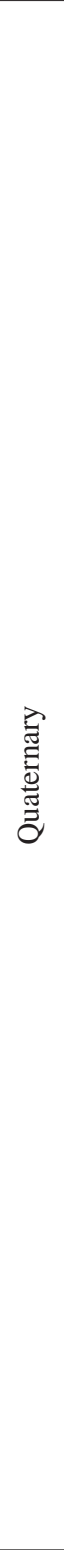 } & \multirow{12}{*}{ 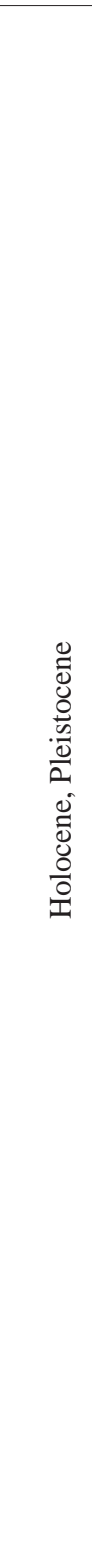 } & $\begin{array}{c}\text { AL } 1 \text { upper } \\
\text { alluvial aquifer }\end{array}$ & Qal, af, Qp & Qa, & \multirow{6}{*}{$\begin{array}{c}\text { Aquifer A: } \\
\text { includes Steilacoom } \\
\text { gravel, Vashon Till, } \\
\text { Vashon advance } \\
\text { outwash, Esperance Sand }\end{array}$} & Recent Holocene alluvium \\
\hline & & MFL confining unit & & Qvl(o), Qvl(e) & & $\begin{array}{l}\text { Volcanic } \\
\text { mudflow-lahar } \\
\text { deposits }\end{array}$ \\
\hline & & $\begin{array}{c}\text { AL } 2 \text { lower } \\
\text { alluvial aquifer }\end{array}$ & & & & $\begin{array}{c}\text { Older Holocene } \\
\text { alluvium and ancient } \\
\text { deltaic deposits beneath } \\
\text { MFL within major river } \\
\text { valleys (Dragovich and } \\
\text { others, 1994) }\end{array}$ \\
\hline & & $\mathbf{A} \mathbf{1}$ aquifer & $\begin{array}{l}\text { Qal, Qv, Qvr, } \\
\text { Qvry, Qvs, Qw }\end{array}$ & $\begin{array}{l}\text { Qa, Qgd, Qgo, } \\
\text { Qgog, Qgos, Qp }\end{array}$ & & $\begin{array}{c}\text { Vashon Drift } \\
\text { (Steilacoom gravel, } \\
\text { recessional outwash }\end{array}$ \\
\hline & & A2 confining unit & Qvt, Qvi, Qvrl & Qgm, Qgt, Qgl & & $\begin{array}{c}\text { Vashon Drift } \\
\text { (till, moraine, } \\
\text { recessional ice-contact, } \\
\text { and lacustrine deposits) }\end{array}$ \\
\hline & & A3 aquifer & Qva, Qpfc & Qga & & $\begin{array}{c}\text { Vashon Drift } \\
\text { (advance outwash) }\end{array}$ \\
\hline & & B confining unit & $\begin{array}{l}\text { m, af, Qal, Qb, } \\
\text { Qf, Qls, Qns, } \\
\text { Qob, Qpdc, Qpf, } \\
\text { Qpoc, Qpon, Qtf, } \\
\text { Qvlc, Qwbc }\end{array}$ & $\mathrm{Qc}(\mathrm{k})$ & Layer B & $\begin{array}{c}\text { Olympia Beds } \\
\text { (Kitsap Formation), } \\
\text { Lawton Clay }\end{array}$ \\
\hline & & C aquifer & Qpog, Qpogc & Qgp & Aquifer $\mathrm{C}$ & $\begin{array}{c}\text { Salmon Springs Drift, } \\
\text { Penultimate Drift, Hayden } \\
\text { Creek Drift, Wingate Hill } \\
\text { Drift } \\
\end{array}$ \\
\hline & & D confining unit & & & Layer D & Puyallup Formation \\
\hline & & E aquifer & & & Aquifer $\mathrm{E}$ & Stuck Drift \\
\hline & & $\mathbf{F}$ confining unit & & & Layer F & Alderton Formation \\
\hline & & $\begin{array}{l}\text { G undifferentiated } \\
\text { deposits }\end{array}$ & & & Aquifer G & $\begin{array}{l}\text { Orting Drift and } \\
\text { older deposits }\end{array}$ \\
\hline 莺 & 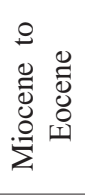 & Bedrock unit & & $\begin{array}{c}\text { Qap, Qap(h), } \\
\text { Qapt(h), Qap(wh), } \\
\text { Qapt(wh), and all } \\
\text { pre-Quaternary } \\
\text { deposits }\end{array}$ & & $\begin{array}{l}\text { Basement confining } \\
\text { unit and some alpine } \\
\text { glacial deposits }\end{array}$ \\
\hline
\end{tabular}


The surficial hydrogeologic map and lithologic data from 1,012 drillers' logs were used to construct multiple hydrogeologic cross sections using Aquaveo ${ }^{\mathrm{TM}}$ ArcHydro Subsurface Analyst tools for ArcGIS ${ }^{\circledR}$ to identify and correlate the hydrogeologic units in the subsurface. Eight representative hydrogeologic sections are shown on plate 3. Hydrogeologic units were assigned to the various lithologic layers depicted in each well log. Hydrogeologic unit assignments were used to delineate the extent of each unit throughout the study area. The altitude of the unit top surface was interpolated in a Geographic Information System (GIS) at a 100-ft interpolation grid cell size, using a method based on the Australian National University Digital Elevation Model procedure developed by Hutchinson (1989). Hydrogeologic unit top surfaces were constrained to a digital elevation model where the unit cropped out. If part of a unit surface was interpolated above the top of an overlying unit, then minimum thickness values for the overlying unit were used in the calculations to adjust the altitude of the top of the underlying unit where needed. This over-interpolation primarily occurred in areas where bedrock is overlain by relatively thin unconsolidated deposits (less than $100 \mathrm{ft}$ thick) or where there were large gaps in the data coverage. Unit thickness maps were created by using GIS to calculate the difference between the top of a unit and the interpolated top of the underlying unit(s). The altitude of the top of bedrock was calculated in a GIS using contours representing the top of the basement confining unit from Jones (1996), land-surface altitudes where bedrock crops out, and point-elevation values from wells that penetrated bedrock in the study area. Residuals were calculated as the difference between the unit surface altitudes assigned for a specific well log and unit altitudes of the interpolated digital hydrogeologic surfaces at the location of the well. Statistics on the residuals were determined for each hydrogeologic unit, excluding the AL1 upper alluvial aquifer, to provide a quantitative comparison between the specific well log data and the interpolated surfaces for the entire study area (table 2; fig. 2). Residuals commonly were within $\pm 6 \mathrm{ft}$ for most hydrogeologic units, however, residuals greater than $\pm 6 \mathrm{ft}$ were frequently observed for the AL2 and E aquifer units, the F confining unit, and $\mathrm{G}$ undifferentiated deposits. The absolute mean difference for all hydrogeologic units was within about $8.5 \mathrm{ft}$.

\section{Streamflow}

Streamflow analysis in the study area included the evaluation of continuous streamflow data during October 2011-October 2012 from 26 USGS streamflow-gaging stations, 2 streamflow measurements from 33 USGS synoptic streamflow sites, 2 streamflow measurements from 3 Lakehaven Utility District streamflow sites conducted by Robinson Noble, Inc. (Burt Clothier, written commun., 2014), and 1 streamflow-gaging station operated by King County. These data (pl. 4) were used to quantify the amount of surface water leaving the study area and to delineate gaining and losing stream reaches during low-flow conditions. Streamflow measurements at USGS streamflow-gaging stations and synoptic sites were made by USGS personnel using Price (pygmy or AA) and FlowTracker Handheld $\mathrm{ADV}^{\circledR}$ current velocity meters according to standard USGS techniques (Rantz and others, 1982). The USGS assigns an accuracy to streamflow measurements based on the equipment, character of the measurement section, number of observations, stability of stage, wind conditions, and the accuracy of depth and velocity measurements (Rantz and others, 1982). Accuracy ratings of "good" indicate that the measurements are judged to be within 5 percent of true values, ratings of "fair" indicate that the measurements are judged to be within 8 percent of true values, and ratings of "poor" indicate that the measurements are judged to be more than 8 percent of true values (assumed to be within 11 percent of true values for this study).

Table 2. Statistics for the interpolated digital hydrogeologic surfaces.

[C ount refers to number of wells or data points used for the interpolation of altitudes of digital hydrogeologic surfaces. A bsolute mean difference is average absolute difference between the interpreted hydrogeologic unit altitudes taken from the well logs and the altitudes of the interpolated digital hydrogeologic surfaces. M inimum and maximum differences are those measured from the interpreted hydrogeologic unit altitudes taken from the well logs and the altitudes of the interpolated digital hydrogeologic surfaces]

\begin{tabular}{|c|c|c|c|c|c|}
\hline \multirow{2}{*}{ Hydrogeologic units } & \multirow{2}{*}{ Count } & \multicolumn{3}{|c|}{ Difference (feet) } & \multirow{2}{*}{$\begin{array}{l}\text { Standard } \\
\text { deviation }\end{array}$} \\
\hline & & Absolute mean & Minimum & Maximum & \\
\hline MFL confining unit & 248 & 0.89 & -24.97 & 8.39 & 2.25 \\
\hline AL2 lower alluvial aquifer & 87 & 4.90 & -82.83 & 61.32 & 13.5 \\
\hline A1 aquifer & 305 & 0.48 & -20.94 & 4.96 & 1.54 \\
\hline A2 confining unit & 726 & 1.80 & -75.50 & 45.03 & 5.57 \\
\hline A3 aquifer & 603 & 2.10 & -33.68 & 20.33 & 4.12 \\
\hline B confining unit & 382 & 2.59 & -80.42 & 49.43 & 6.7 \\
\hline $\mathrm{C}$ aquifer & 391 & 3.43 & -105.13 & 48.41 & 9.09 \\
\hline D confining unit & 195 & 3.71 & -98.54 & 39.68 & 9.57 \\
\hline E aquifer & 125 & 6.22 & -26.20 & 110.30 & 14.17 \\
\hline F confining unit & 87 & 3.76 & -45.03 & 30.16 & 9.25 \\
\hline G undifferentiated deposits & 78 & 8.53 & -87.30 & 130.89 & 22.34 \\
\hline
\end{tabular}



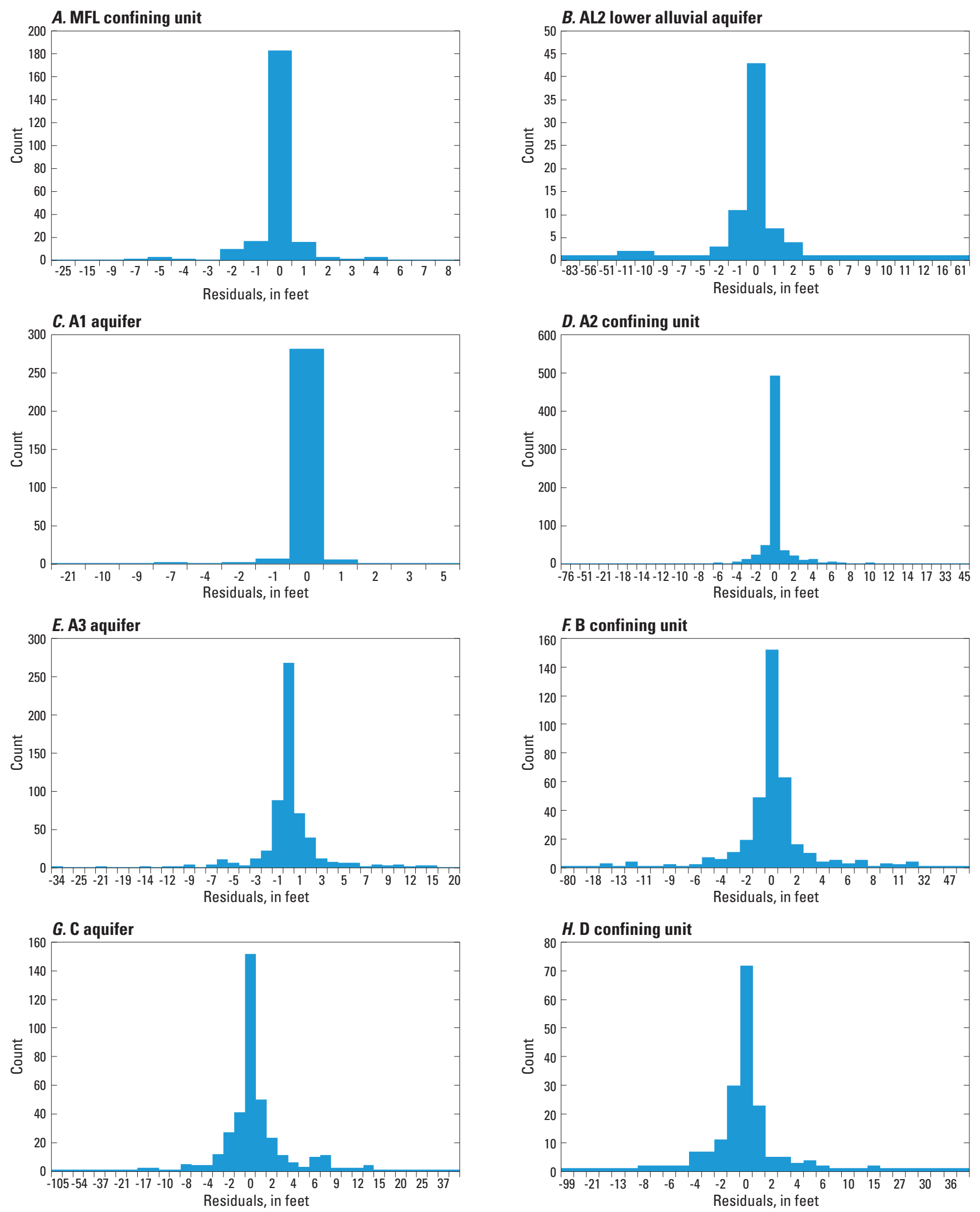

Figure 2. Residuals between hydrogeologic unit correlation altitudes and altitudes of interpolated digital hydrogeologic surfaces, Puyallup River Watershed and vicinity, Washington. 

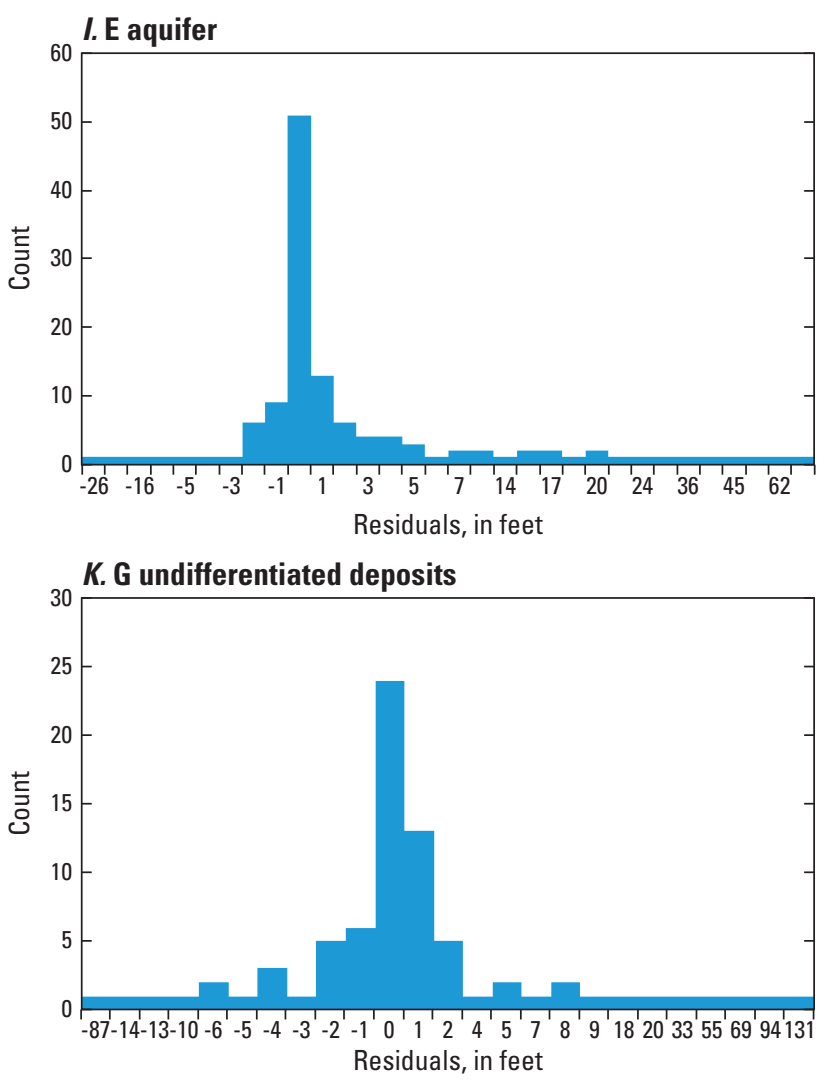

Figure 2.-Continued

Numerous springs are present throughout the study area which contribute baseflow to streams and groundwater discharge to Puget Sound along shoreline bluffs throughout the year. A field inventory of springs was not conducted during this investigation. Descriptions of spring locations and historical discharge were compiled and evaluated from several sources including: Walters and Kimmel (1968), Luzier (1969), Jones and others (1999), Savoca and others (2010); and records from local municipalities, public water supply systems, the Washington State Department of Health (WADOH), and USGS NWIS database.

\section{Hydrogeologic Framework}

This section describes the geology and hydrogeologic framework, which define the physical, lithologic, and hydrologic characteristics of the hydrogeologic units that compose the groundwater-flow system in the study area. An understanding of these characteristics is important in determining the occurrence, movement, and availability of groundwater in the aquifer system, and the exchange of water between the aquifer system and surface-water features.

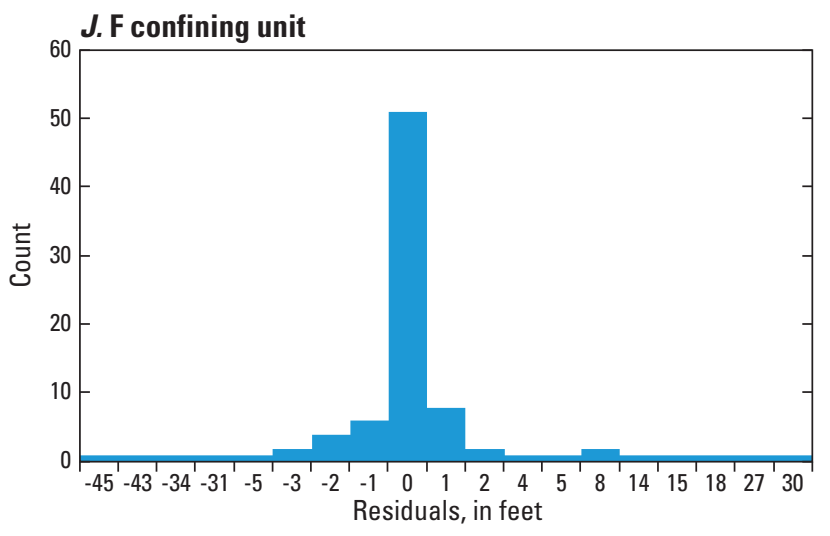

\section{Geologic Setting}

The following brief summary of major geologic events in the study area is based on the work of Walters and Kimmel (1968), Luzier (1969), Dragovich and others (1994), and Jones (1999). The advance and retreat of continental glaciers and intervening nonglacial periods of deposition during the Pleistocene Epoch of the Quaternary Period left behind more than 3,000 ft of unconsolidated deposits in the Puget Lowland and about 2,000 ft of deposits within the study area. These deposits form the hydrogeologic units defined in this study and will be the focus of the remaining discussion.

The Puget Lobe of the Cordilleran ice sheet has advanced and retreated several times into the Puget Lowland from the mountains of British Columbia since the beginning of the Quaternary and has left behind a complex sequence of alternating glacial and interglacial sediments. The Vashon Stade of the Fraser Glaciation was the most recent (beginning about 17,000 years ago) and extensive of the major advances. Glacial sediment typically includes (in order of deposition) outwash sand and gravels deposited by the advancing ice; glacial till (hard and poorly sorted mixture of clay, silt, sand, and gravel) and ice-contact material deposited beneath and adjacent to the ice; and outwash sand and gravels at the top of the sequence deposited by the retreating ice. 
Each major glacial interval was followed by an extended interglacial period (interstade) during which fluvial, lacustrine, bog, and marsh depositional environments dominated. Interglacial deposits typically consist of clay, silt, discontinuous lenses of sand and gravel, and peat. Underlying the unconsolidated glacial and interglacial deposits are Tertiary bedrock units comprised mainly of sedimentary claystone, siltstone, sandstone, beds of coal, and volcanic rocks. Alpine glacial deposits are locally present mainly in bedrock-dominated areas in the eastern part of the study area.

During the most recent interstade (beginning about 14,000 years ago), the climate warmed and the Puget Lobe retreated northward. This allowed marine waters to inundate the Puget Sound Basin, which had been depressed because of glacial isostatic loading. Postglacial filling of the ancestral Puyallup River and Duwamish River valleys, which had been excavated by subglacial melt water, was accomplished through Holocene marine, lacustrine, deltaic, and fluvial deposition, as well as volcanic mudflow-lahar deposits originating from Mount Rainier.

\section{Hydrogeologic Units}

Geologic units were grouped into hydrogeologic units consisting of aquifers and confining units (table 1) based on similarities in lithology (grain size and sorting), hydrologic characteristics, and relative stratigraphic position. The hydrogeologic units defined in this study are based on units defined by previous investigations in the study area (Brown and Caldwell, 1985; Robinson \& Noble, Inc., and others, 2003; Savoca and others, 2010). Differences between units defined in this study and the most recent previous investigation (Savoca and others, 2010) include the addition of mudflow-lahar deposits (MFL) and lower alluvial deposits (AL2). In keeping with the most recent previous investigation, the use of hydrostratigraphic units in which all glacial deposits are characterized as aquifers and interglacial deposits are characterized as confining units has been discontinued, in favor of the use of hydrogeologic units in which aquifers and confining unit designations are based on the lithologic and hydrologic characteristics of deposits regardless of depositional environment (for example, an aquifer unit may consist of both glacial outwash and interglacial alluvial deposits). Hydrogeologic units defined in this study are not directly comparable (with respect to unit extent or thickness) to previously published units.

An aquifer is saturated geologic material that is sufficiently permeable to yield water in significant quantities to a well or spring, whereas a confining unit has low permeability that restricts the movement of groundwater and limits the usefulness of the unit as a water source. Unconfined and confined aquifer conditions are present in the study area.
Unconfined or "water-table" conditions occur when the upper surface of the saturated zone is at atmospheric pressure and is free to rise and decline in response to changes in groundwater recharge and discharge. The position of the water table is represented by water levels in shallow wells. Confined or "artesian" conditions occur when an aquifer is overlain by a less permeable confining unit and the groundwater is under pressure greater than atmospheric pressure. Water in a tightly cased well drilled into a confined aquifer will rise to a height corresponding to the hydraulic head (the potentiometric surface) of the confined groundwater at that location. If the hydraulic head is sufficient to raise the water above land surface, the well will flow and is referred to as a flowing artesian well. The potentiometric surface in a confined aquifer is analogous to the water table in an unconfined aquifer. The potentiometric surface fluctuates in response to changes in recharge and discharge; however, unlike the water table, the potentiometric surface is higher in altitude than the top of the confined aquifer.

Glacial deposits generally are heterogeneous, and although a glacial aquifer may be primarily composed of sand or gravel, it may locally contain varying amounts of clay or silt. Conversely, a confining layer composed predominantly of silt or clay may contain local lenses of coarse material. These small-scale variations in lithology may influence the occurrence and movement of groundwater at a scale that likely is too small to be adequately represented by the hydrogeologic framework constructed for this study. In the Puget Lowland, aquifers primarily consist of glacial outwash but also may include coarse-grained interglacial deposits. The confining units primarily consist of fine-grained interglacial deposits but also may include glacial till or glaciolacustrine deposits. Unconsolidated glacial and interglacial aquifer and confining units are underlain by low-permeability Tertiary bedrock units, described as the basement confining unit in Jones (1999). Thirteen hydrogeologic units are recognized in the study area (table 1, pl. 2) and their lithologic and hydrologic characteristics are described here.

AL 1 upper alluvial aquifer.-The AL1 upper alluvial aquifer is present throughout the Puyallup River, Carbon River, White River, and Green River valleys, along South Prairie Creek, and within the Auburn Valley (pl. 2), and includes alluvial (Qal and Qa), and tide flat and artificial fill (Qp and af) deposits. This hydrogeologic unit primarily consists of alluvial silt, sand, and gravel deposits that closely follow Holocene river valleys, and locally contain lenses of clay. The unit generally is less than $100 \mathrm{ft}$ thick, but exceeds $240 \mathrm{ft}$ along the Puyallup River as it nears Commencement Bay and within the northern part of the Auburn Valley (fig. 3). Groundwater in this aquifer generally is unconfined; however, confined conditions may occur locally beneath silt and clay deposits. 


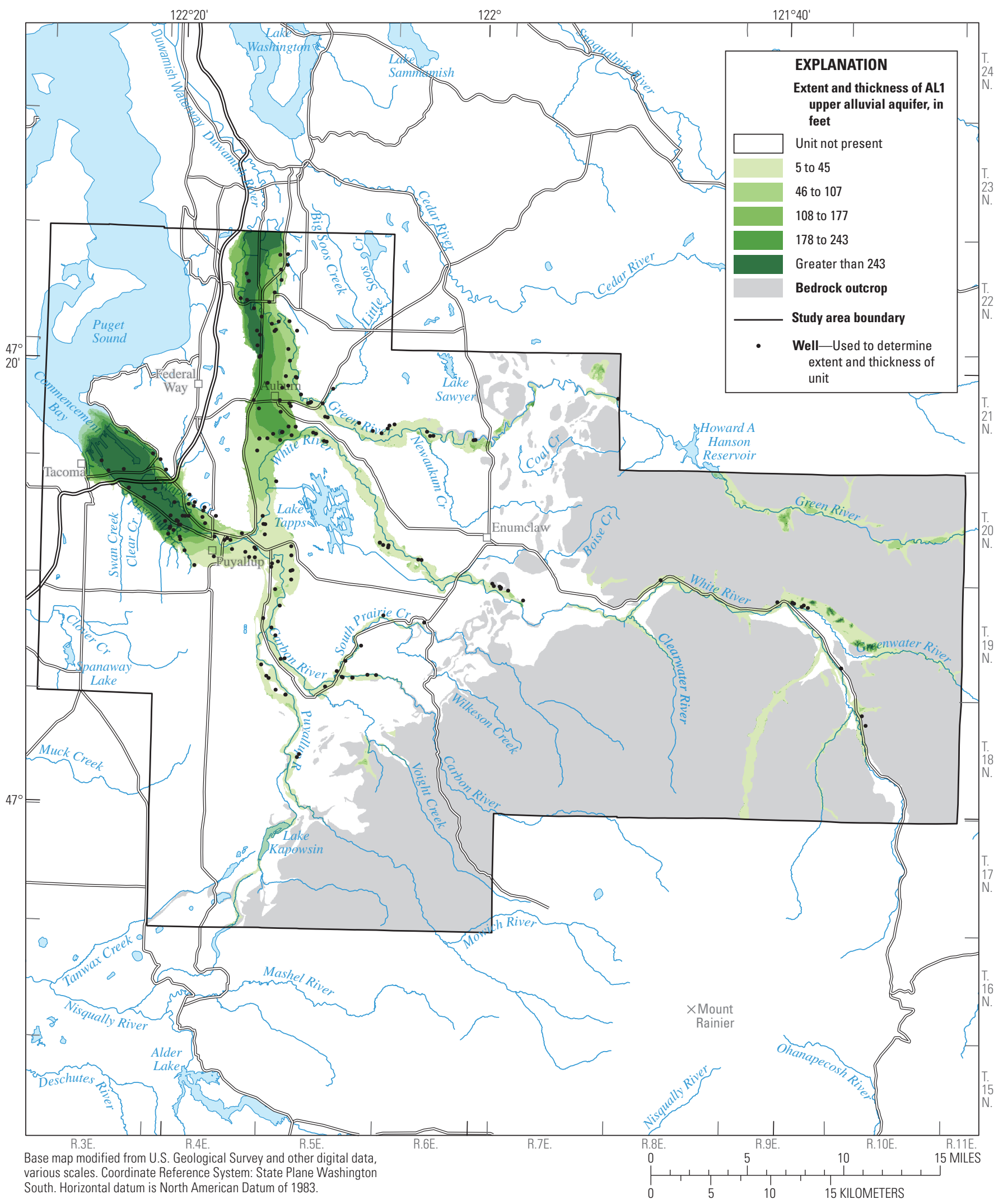

Figure 3. Extent and thickness of AL1 upper alluvial aquifer in Puyallup River Watershed and vicinity, Washington. 
MFL confining unit.- The MFL confining unit is present at land surface throughout upland areas in the central part of the study area, and along the Puyallup River and Auburn Valleys, along the White River and several of its tributaries, and along South Prairie Creek (pl. 2). In the subsurface (fig. 4), this low-permeability unit is present within all major river valleys in the study area except for the White River valley. The White River valley abandoned its ancestral course down what is now South Prairie Creek valley during deposition of the Osceola Mudflow (Qvl(o)) about 5,700 years ago, and then it rapidly incised the newly deposited mudflow sediments along its present river course (Dragovich and others, 1994). Deposits from the less extensive Electron Mudflow (Qvl(e); about 1,500 years ago) occur along the Puyallup River valley (Scott and Vallance, 1995; Cakir and Walsh, 2014). The MFL confining unit (Qvl(o) and Qvl(e)) consists of unsorted, unstratified mixtures of pebble to boulder size rock fragments in a clay, silt, and sand matrix derived from Mount Rainier. The unit generally is less than $50 \mathrm{ft}$ thick, but exceeds $135 \mathrm{ft}$ along parts of the Puyallup River and Auburn Valleys, and within upland areas in the central part of the study area (fig. 4).

A L 2 lower alluvial aquifer.-The AL2 lower alluvial aquifer is present beneath the MFL confining unit within the Puyallup River, Auburn, and Green River valleys, and the upper reaches of the White River (fig. 5) and primarily consists of older Holocene alluvium and ancient deltaic deposits that accumulated along the estuarine margins of the ancestral Puyallup River and Duwamish River valleys during the early to middle Holocene (Dragovich and others, 1994).

Because of the spatial variability of stream sediments, and the inclusion of proximal to distal deltaic deposits, the lithologic character of this unit is quite heterogeneous and varies greatly with depth. The average thickness of the unit is about $110 \mathrm{ft}$, but exceeds $250 \mathrm{ft}$ within the Auburn Valley (fig. 5). Groundwater in this aquifer generally is confined; however, unconfined conditions may occur in areas where the overlying MFL confining unit is locally thin or absent.

A 1 aquifer. - The $\mathrm{A} 1$ aquifer is present at land surface throughout east-central and south-central parts of the study area (pl. 2) and is composed primarily of Vashon recessional outwash (Qvr) deposits of the Fraser Glaciation. These deposits consist of stratified silt, sand, and gravel deposited by large meltwater streams formed during the northward retreat of the Puget Lobe. A subdivision of Qvr deposits, known as the
Steilacoom Gravels (Qvs), are present in successive outwash channels formed by streamflow originating from proglacial Lake Puyallup (Walters and Kimmel, 1968). These gravels are characterized by their consistency and coarseness over a large part of the study area. Wetland $(\mathrm{Qw})$ and peat $(\mathrm{Qp})$ deposits were included in the A1 aquifer unit in areas where these typically thin (less than $10 \mathrm{ft}$ ) deposits discontinuously overlie the A1 aquifer. Undifferentiated Vashon drift (Qv) deposits were included in the A1 aquifer in areas where they are in close proximity to other recessional deposits. Some alluvial deposits (Qa and Qal) that were not connected with river valleys also were grouped with the $\mathrm{A} 1$ aquifer unit. The thickness of the A1 aquifer typically ranges from a thin veneer of less than 30 to about $80 \mathrm{ft}$, but can locally exceed $260 \mathrm{ft}$ where underlying units are not present (fig. 6). Groundwater generally is unconfined in this aquifer.

A2 confining unit.- The $\mathrm{A} 2$ confining unit is present at land surface throughout central and western parts of the study area (pl. 2) and is composed of Vashon till (Qvt) and lesser amounts of moraine (Qgm) deposits. This low-permeability unit is absent within most major river valleys, and consists of various proportions of clay, silt, sand, and gravel, with locally occurring sand and gravel lenses capable of providing water for domestic use. Ice-contact (Qvi) deposits, present at land surface along bluffs and adjacent uplands of the Puyallup River and Green River valleys, and glaciolacustrine (Qvrl and Qgl) deposits are included in the A2 confining unit. The thickness of the A2 confining unit varies spatially from a thin veneer of less than 45 to about $130 \mathrm{ft}$, but can locally exceed $200 \mathrm{ft}$ (fig. 7).

A3 aquifer.-The $\mathrm{A} 3$ aquifer is present in the subsurface throughout central and western parts of the study area (fig. 8), with surface exposures limited to a few steep slopes and along the walls of deeply incised river valleys and coastal bluffs (pl. 2). The unit is absent within most major river valleys. It is primarily composed of Vashon advance outwash (Qva) and small amounts of Pre-Fraser coarse-grained, non-glacial deposits (Qpfc), and consists of well-sorted sand or sand and gravel, with lenses of silt and clay. The thickness of the A3 aquifer ranges from less than 40 to about $120 \mathrm{ft}$, but can locally exceed $185 \mathrm{ft}$ (fig. 8). Groundwater in this aquifer generally is confined by the overlying A2 confining unit; however, unconfined conditions may occur locally where it is not fully saturated or is exposed at land surface. 


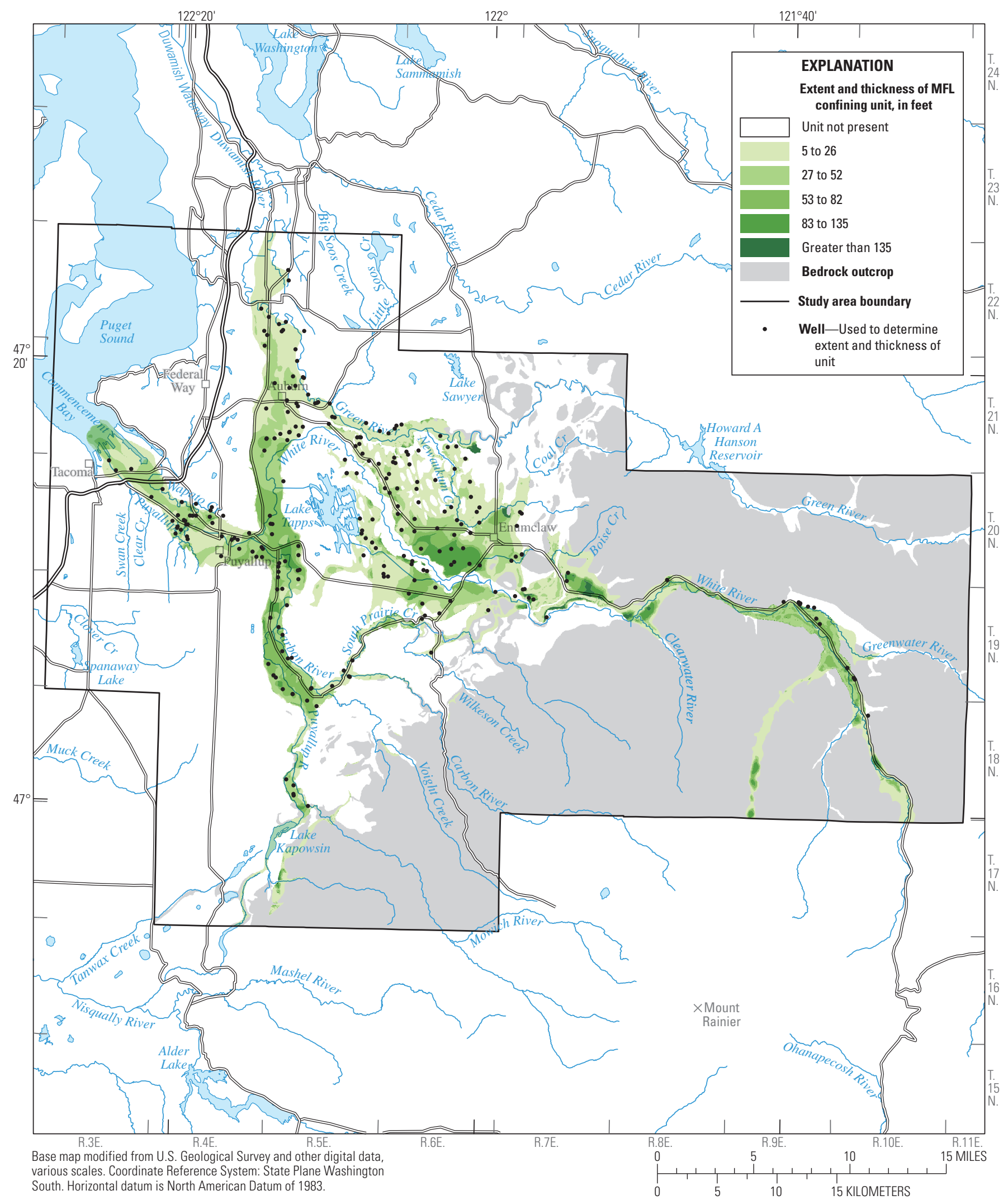

Figure 4. Extent and thickness of MFL confining unit in Puyallup River Watershed and vicinity, Washington. 


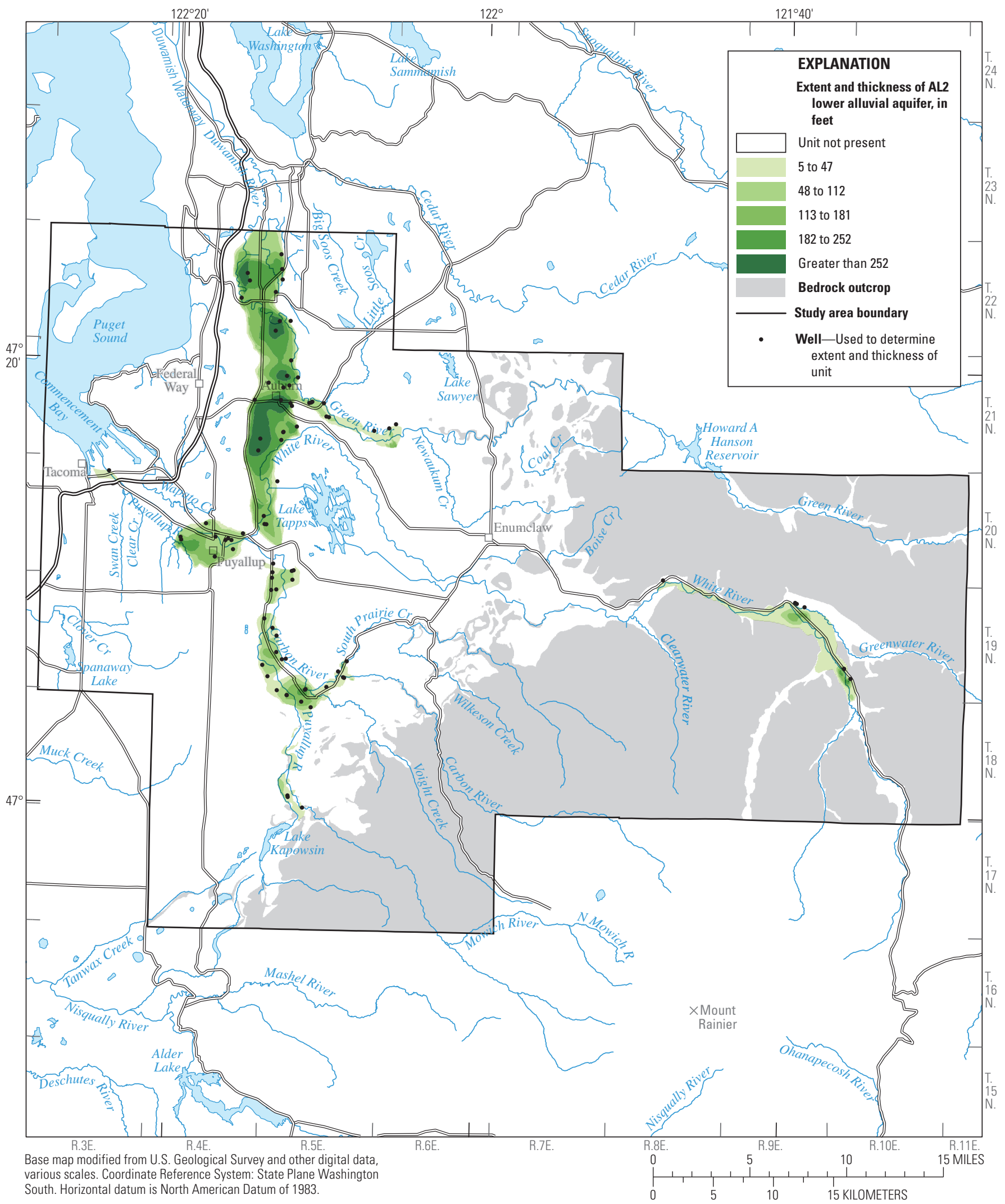

Figure 5. Extent and thickness of AL2 lower alluvial aquifer in Puyallup River Watershed and vicinity, Washington. 


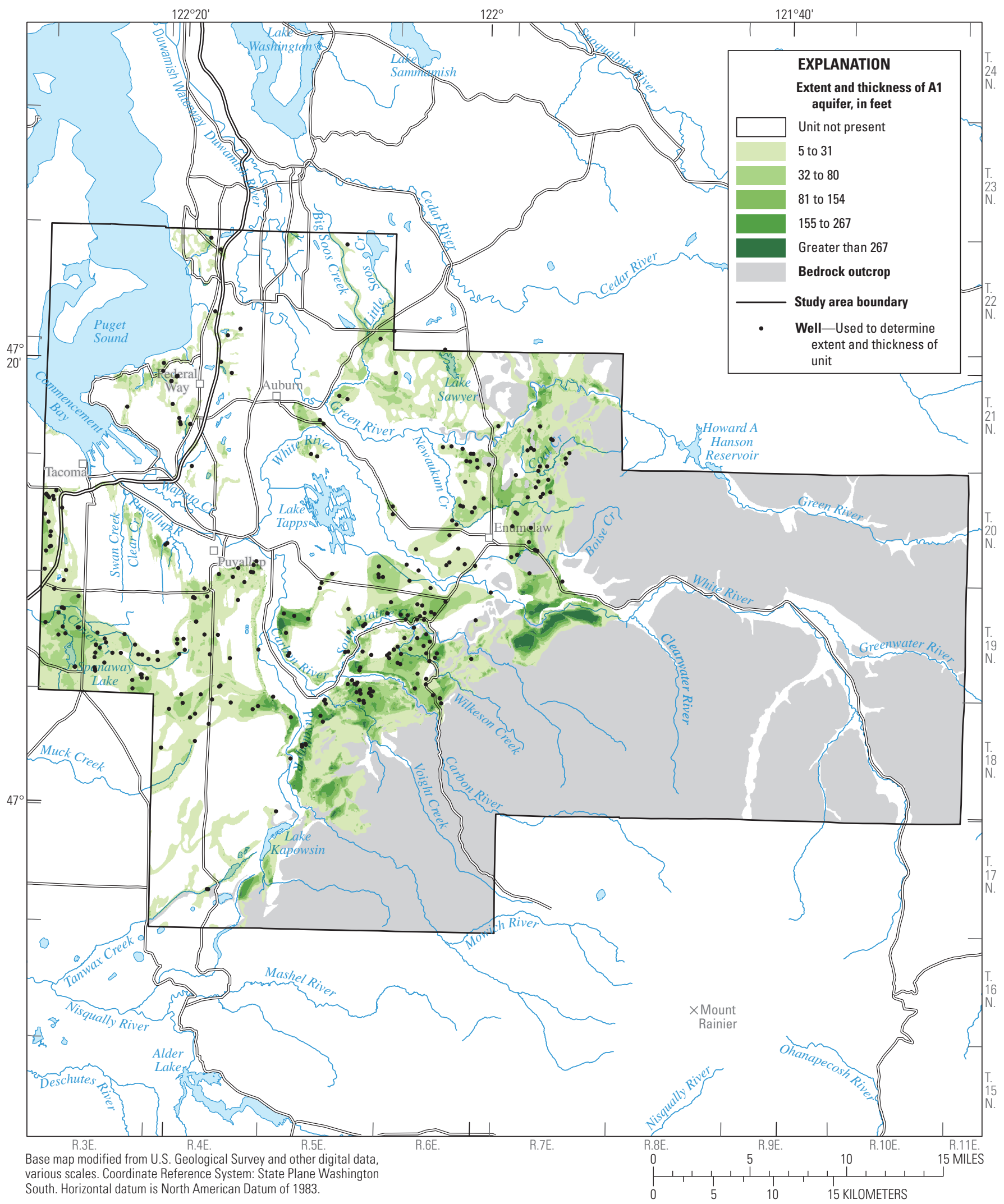

Figure 6. Extent and thickness of A1 aquifer in Puyallup River Watershed and vicinity, Washington. 


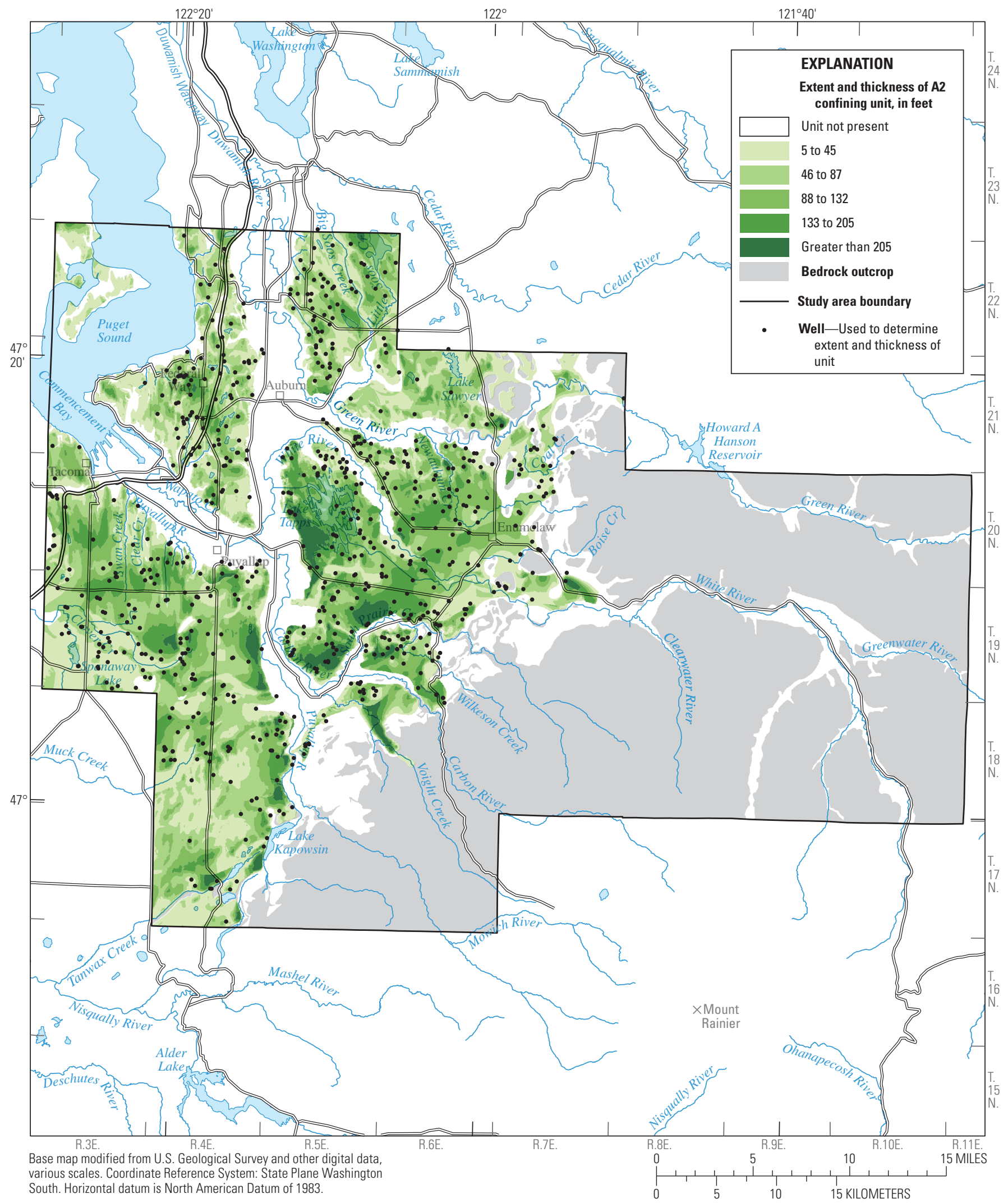

Figure 7. Extent and thickness of $A 2$ confining unit in Puyallup River Watershed and vicinity, Washington. 


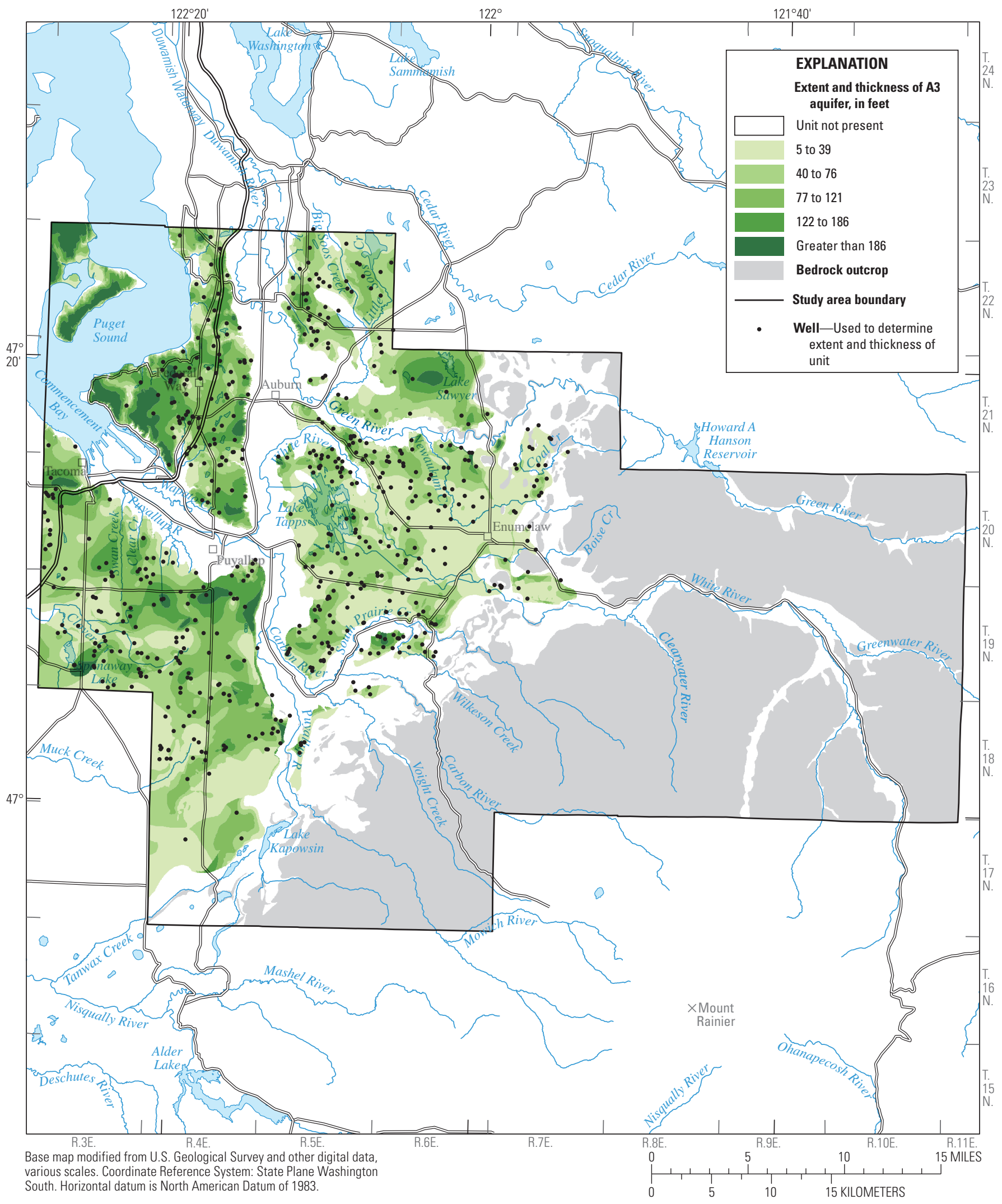

Figure 8. Extent and thickness of $A 3$ aquifer in Puyallup River Watershed and vicinity, Washington. 
B confining unit.- The B confining unit is present in the subsurface throughout central and western parts of the study area (fig. 9) with surface exposures limited to areas along the walls of deeply incised river valleys and coastal bluffs (pl. 2). This low-permeability unit is absent within most major river valleys, and primarily is composed of fine-grained silts and clays (Olympia beds-Qob) deposited during the Olympia interglacial and glaciolacustrine clays deposited during early Vashon (Lawton clay-Qvlc). The B confining unit also includes several additional geologic units (table 1) that are laterally continuous with the Qob and Qvlc deposits or have similar lithologic characteristics. The thickness of the B confining unit ranges from less than 35 to about $115 \mathrm{ft}$, but locally exceeds $175 \mathrm{ft}$ (fig. 9).

C aquifer.-The $\mathrm{C}$ aquifer, often referred to as the sea-level aquifer because of its coincident altitude, is present at high altitudes within upland portions of the study area. The unit also is present in the subsurface throughout central and western parts of the study area and within the Puyallup River and Auburn Valleys (fig. 10). Surface exposures of the $\mathrm{C}$ aquifer are limited to a few areas along the walls of deeply incised river valleys and coastal bluffs (pl. 2). The unit primarily is composed of pre-Olympia glacial drift deposits locally referred to as the Salmon Springs Drift (Walters and Kimmel, 1968) and consists of sand and gravel, with minor lenses of silt, clay, and till. The thickness of the $\mathrm{C}$ aquifer unit ranges from less than 40 to $125 \mathrm{ft}$, but locally exceeds $185 \mathrm{ft}$ (fig. 10). Groundwater in this aquifer generally is confined by the overlying B confining unit. However, unconfined conditions may occur locally where no overlying confining unit is present (figs. 7 and 9), or in places where the unit is not fully saturated.

D confining unit.-The D confining unit is present in the subsurface throughout central and western parts of the study area and within all major river valleys except for the northern Auburn Valley (fig. 11). Surface exposures of the D confining unit are limited to a few areas along the walls of deeply incised river valleys and coastal bluffs. This low-permeability unit most likely correlates with deposits from the Puyallup interglacial and consists of alluvial and lacustrine sand, silt, and clay deposits, and occasional deposits of volcanic ash. The thickness of the D confining unit ranges from less than 60 to $150 \mathrm{ft}$, but locally exceeds $205 \mathrm{ft}$ (fig. 11).

E aquifer.-The E aquifer is present in the subsurface throughout central and western parts of the study area (fig. 12); is not present at land surface in the study area, except where it is exposed beneath the water along the margins of Puget Sound (pl. 2); and is recognized only in drillers' logs. This unit most likely correlates with deposits of the Stuck Drift, the third recognized glaciation of the southern Puget Sound area (Walters and Kimmel, 1968), and primarily consists of silt, sand, and gravel, with discontinuous till and lacustrine deposits. The thickness of the $\mathrm{E}$ aquifer ranges from less than 50 to $155 \mathrm{ft}$, but locally exceeds $245 \mathrm{ft}$ (fig. 12). Groundwater in this aquifer is confined by the overlying $\mathrm{D}$ confining unit.

F confining unit.- The F confining unit is present in the subsurface throughout central and western parts of the study area (fig. 13); is not present at land surface in the study area, except where it is exposed beneath the water along the margins of Puget Sound (pl. 2); and is recognized only in drillers' logs. This low-permeability unit most likely correlates with deposits of the Alderton Formation and primarily consists of silt and clay, with minor lenses of sand and gravel. Limited well data indicate that thicknesses typically range from less than 80 to $190 \mathrm{ft}$; however, thicknesses exceed $270 \mathrm{ft}$ in places (fig. 13).

G undifferentiated deposits.-Undifferentiated deposits assigned to unit $G$ are present in the subsurface throughout central and western parts of the study area (fig. 14); are not present at land surface in the study area, except where exposed beneath the water of Puget Sound (pl. 2); and are recognized only in drillers' logs. The undifferentiated deposits assigned to unit G primarily consist of stratified sand and gravel, with discontinuous layers of till. Few wells in the study area fully penetrate these unconsolidated deposits down to the bedrock surface, and little is known about the spatial distribution of water-bearing and non-water-bearing sediments in the deeper parts of the unconsolidated sequence (Brown and Caldwell, 1985). The uppermost part of unit G likely correlates to the Orting drift, the oldest identified Pleistocene glaciation in the Puget Sound area (Walters and Kimmel, 1968). Several public water-supply systems in the study area withdraw water from the upper part of the unit. Thickness estimates for this unit (fig. 14) were computed by subtracting the top of bedrock from the top of unit $\mathrm{G}$ and range from less than 360 to greater than $1,235 \mathrm{ft}$.

Bedrock unit.-The bedrock unit crops out in foothills and mountainous terrain along the southeastern and eastern margin of the study area (pl. 2). This low-permeability unit consists of sedimentary claystone, siltstone, sandstone, beds of coal, and volcanic rocks. Alpine glacial deposits composed of various proportions of clay, silt, sand, and gravel, overlie some areas of bedrock, and were included in the bedrock unit based on the assumption that these unconsolidated deposits resemble glacial tills, and are primarily non-water bearing. 


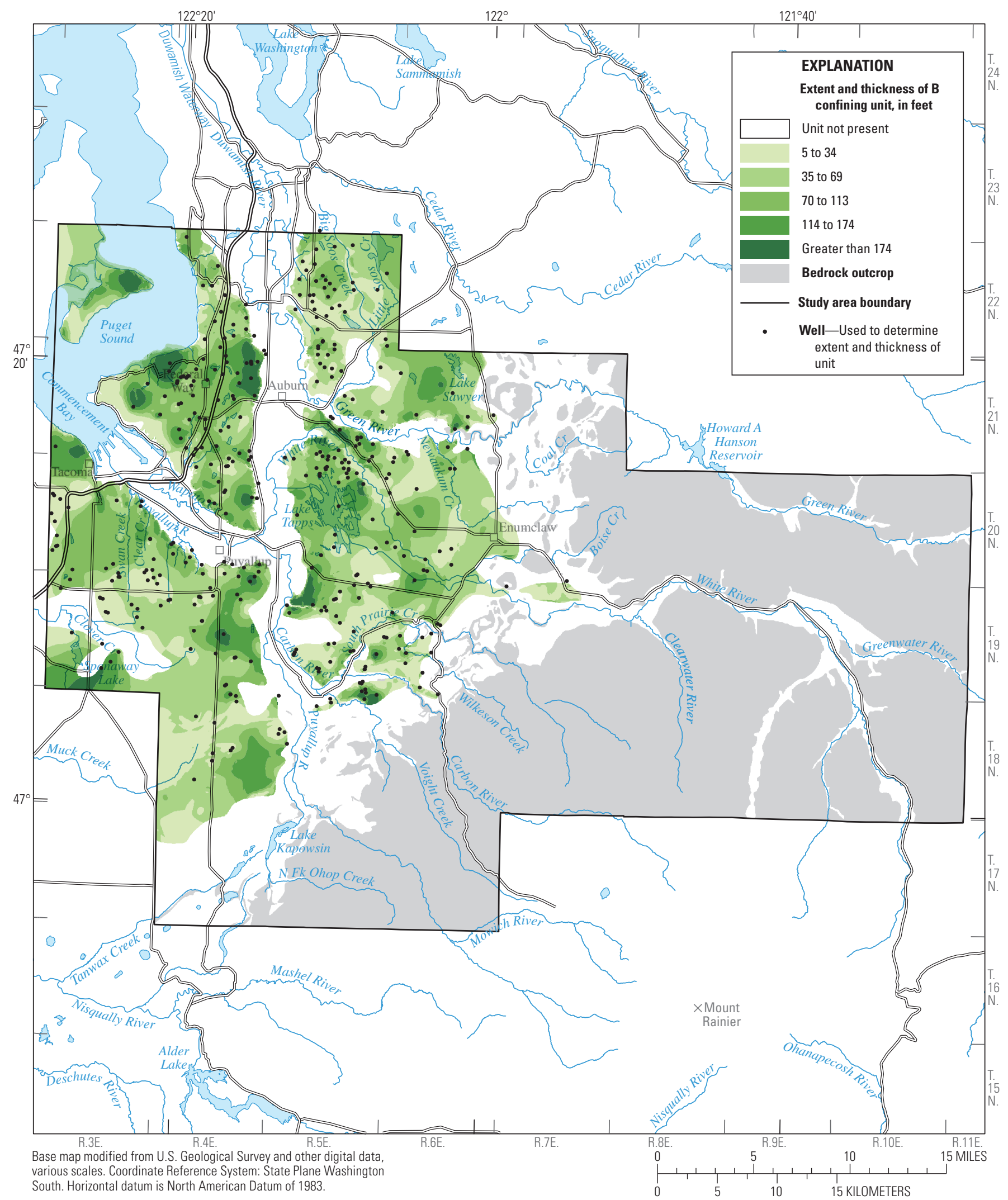

Figure 9. Extent and thickness of B confining unit in Puyallup River Watershed and vicinity, Washington. 


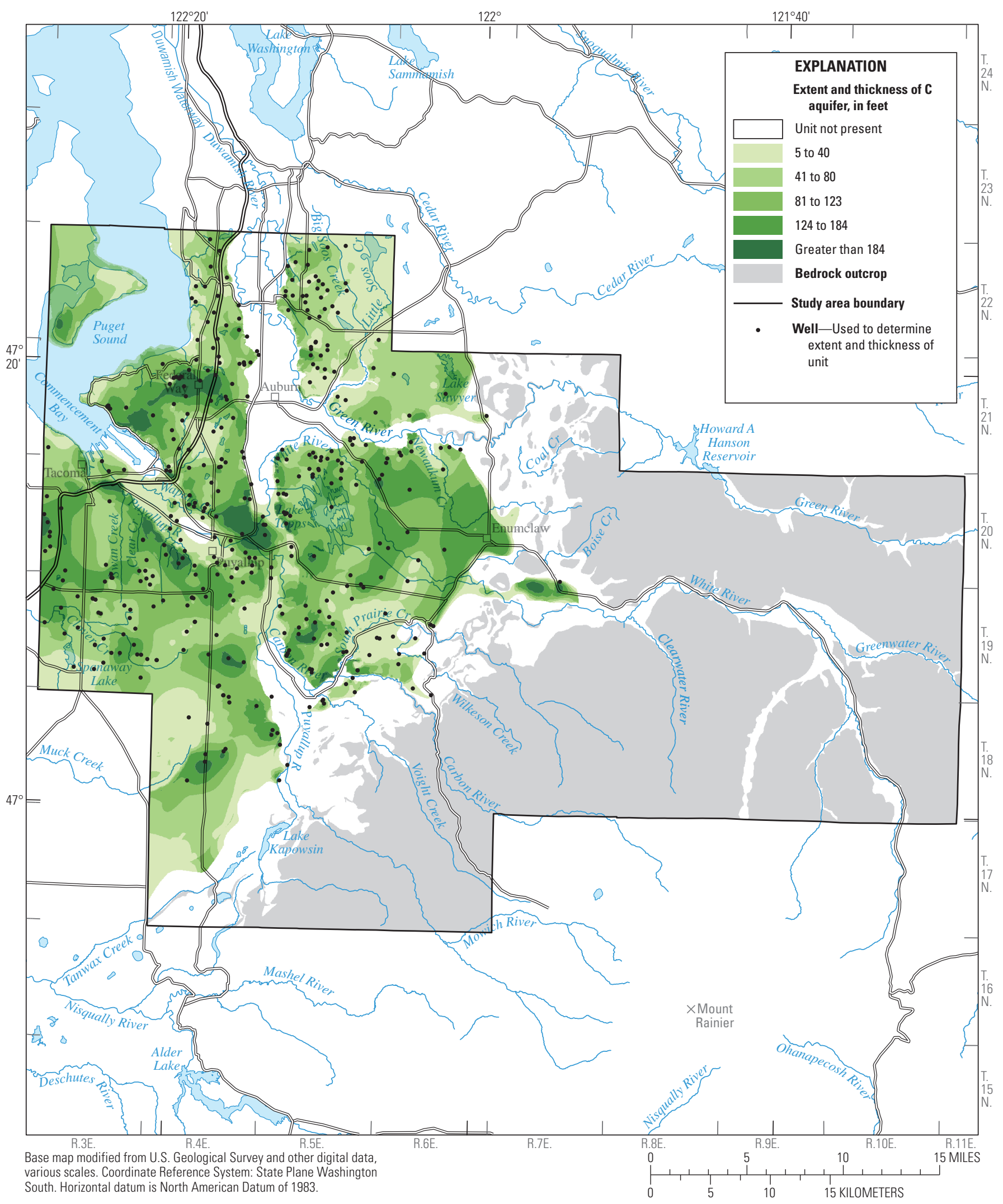

Figure 10. Extent and thickness of $\mathrm{C}$ aquifer in Puyallup River Watershed and vicinity, Washington. 


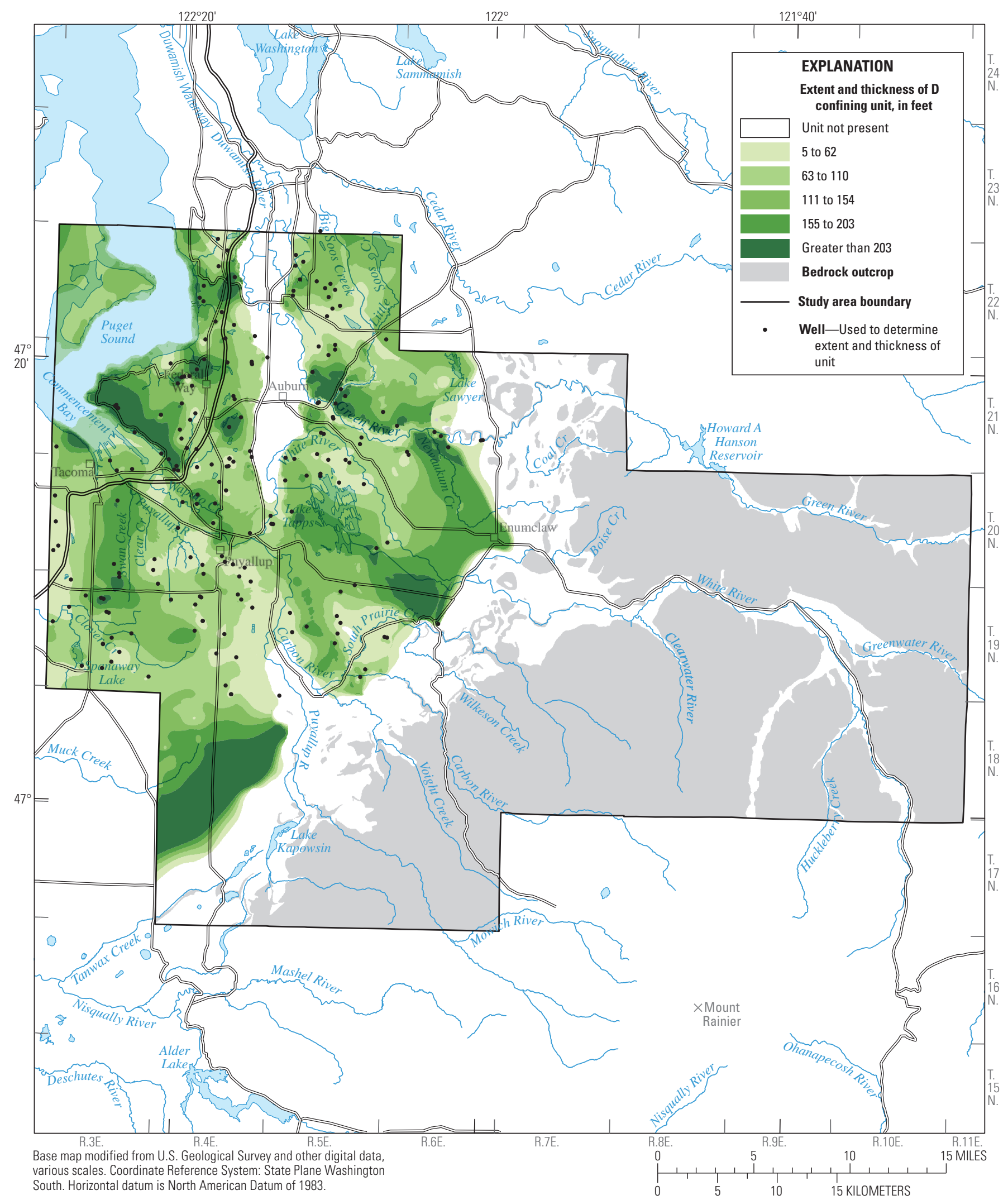

Figure 11. Extent and thickness of $D$ confining unit in Puyallup River Watershed and vicinity, Washington. 


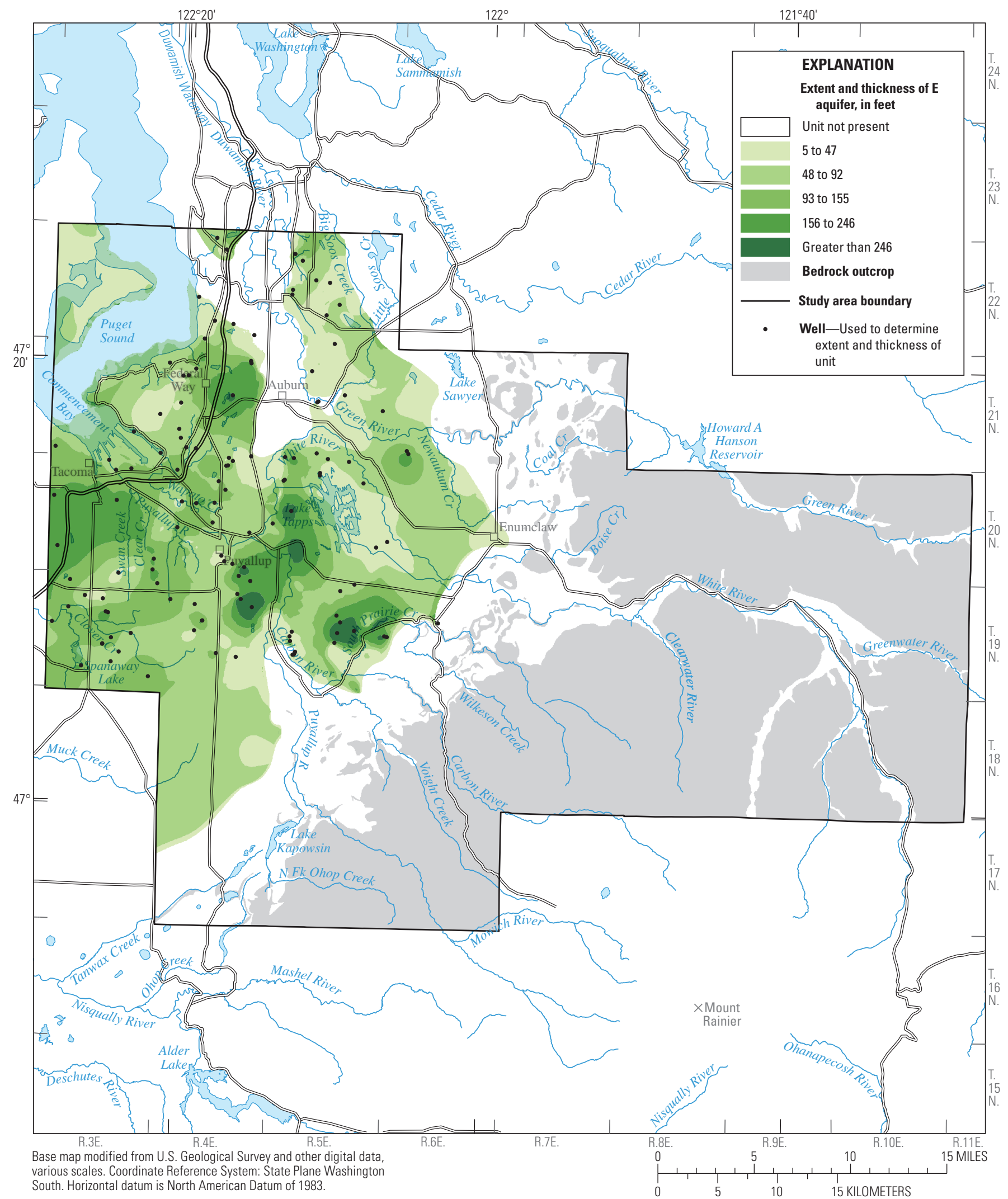

Figure 12. Extent and thickness of $E$ aquifer in Puyallup River Watershed and vicinity, Washington. 


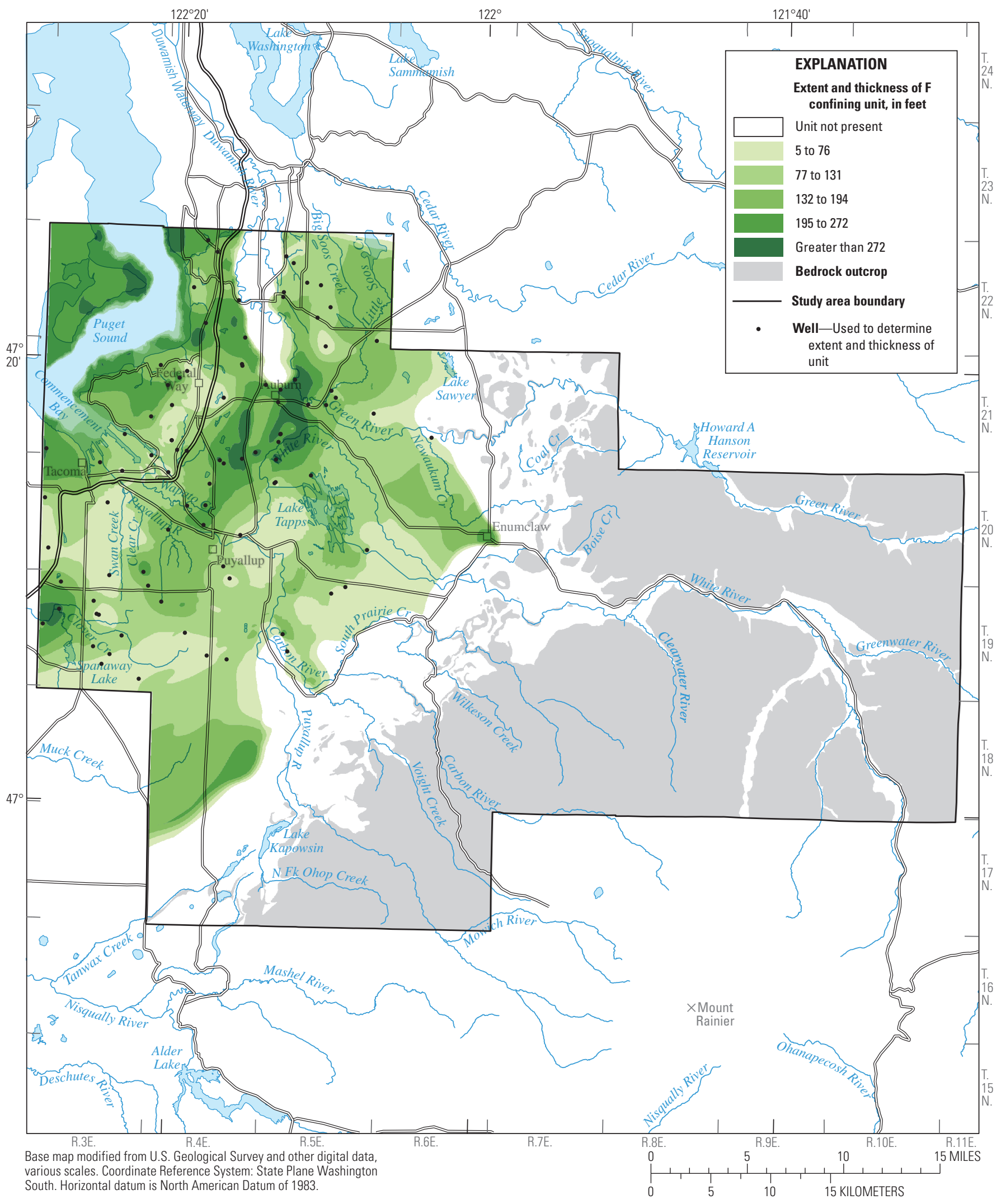

Figure 13. Extent and thickness of $\mathrm{F}$ confining unit in Puyallup River Watershed and vicinity, Washington. 


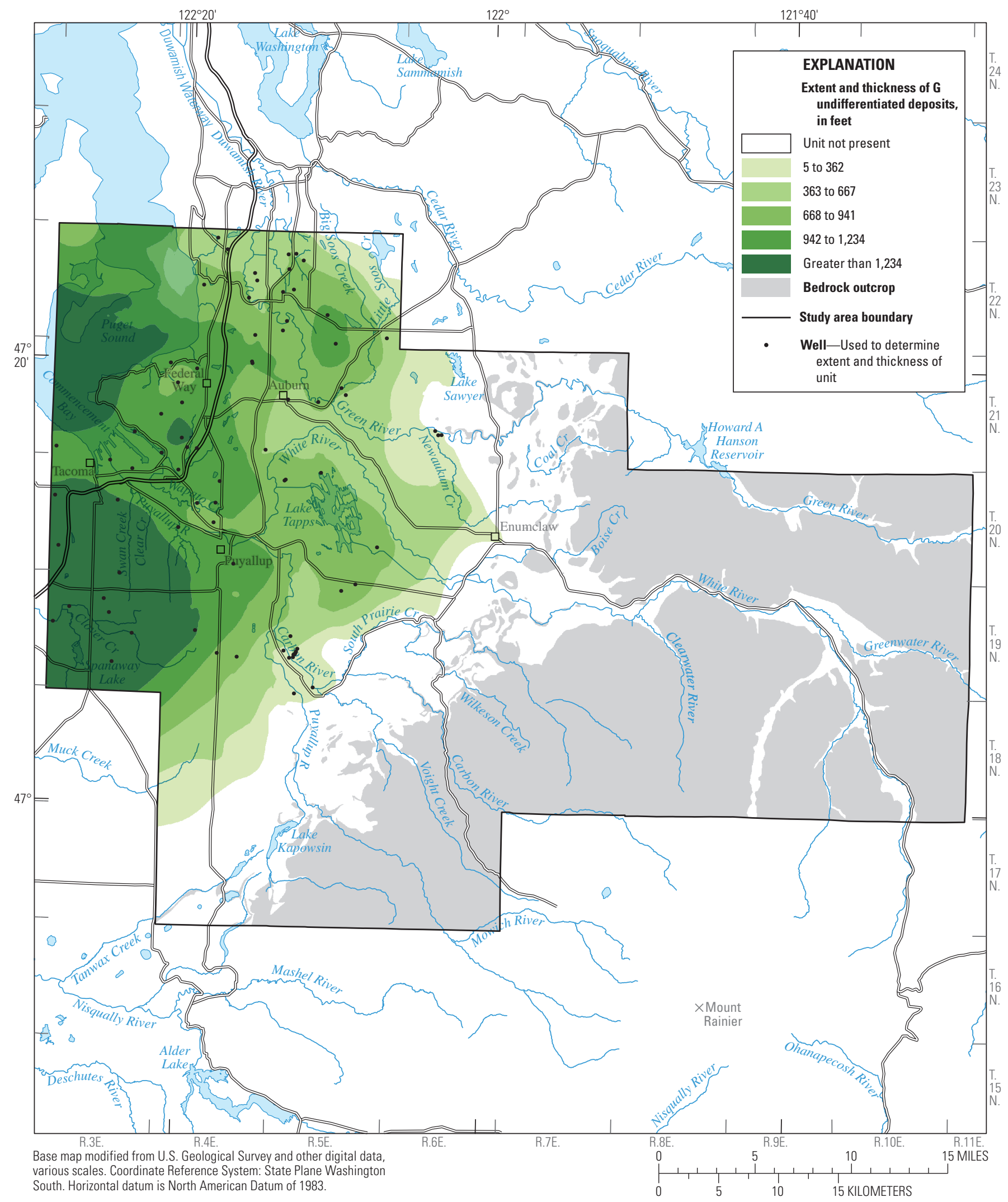

Figure 14. Extent and thickness of $\mathrm{G}$ undifferentiated deposits in Puyallup River Watershed and vicinity, Washington. 


\section{Hydraulic Conductivity}

Hydraulic conductivity is a measure of a material's ability to transmit water, and in unconsolidated sediment, it is dependent on the size, shape, distribution, and packing of the particles. Because these physical characteristics vary greatly within the glacial deposits of the study area, hydraulic conductivity values also are highly variable. Estimates of the magnitude and distribution of hydraulic conductivity were used to develop an understanding of groundwater movement and availability in the hydrogeologic units.

Horizontal hydraulic conductivity was estimated for the hydrogeologic units using specific-capacity data from drillers' logs, and results of aquifer tests conducted by Robinson Noble, Inc. (Burt Clothier, written commun., 2014) and Carr and Associates Inc. (1988). Specific-capacity data (water-level drawdown measured after pumping a well for a specified period of time) were compiled and analyzed for wells that had a drillers' log containing discharge rate, time of pumping, drawdown, static water level, well-construction data, and lithologic descriptions. Of the all wells analyzed for the hydrogeologic framework, 201 wells constructed with a screened or perforated open interval and 30 wells constructed with an open-ended casing met the above criterion. Aquifer tests results were available for 20 public water-supply wells (appendix A).

Two sets of equations were used to estimate hydraulic conductivity from specific-capacity data, depending on well construction. For data from wells with a screened or perforated open interval, the modified Theis equation (Ferris and others, 1962) was first used to estimate transmissivity of the pumped interval. Transmissivity is the product of horizontal hydraulic conductivity and thickness of the part of the hydrogeologic unit supplying water to the well. The modified equation is

$$
s=\frac{Q}{4 \pi T} \ln \frac{2.25 T t}{r^{2} S}
$$

where

$S$ is drawdown in the well, in feet;

Q is discharge, or pumping rate, of the well, in cubic feet per day;

$\mathrm{T}$ is transmissivity of the hydrogeologic unit, in square feet per day;

$t$ is length of time the well was pumped, in days;

$r \quad$ is radius of the well, in feet; and

$\mathrm{S}$ is storage coefficient, a dimensionless number, assumed to be 0.0001 for confined units and 0.1 for unconfined units.
In addition to the assumed storage coefficients, other assumptions for using equation 1 are that (1) aquifers are homogeneous, isotropic, and infinite in extent; (2) wells fully penetrate the aquifer; (3) flow to the well is horizontal; and (4) water is released from storage instantaneously. Additionally, for unconfined aquifers, drawdown is assumed to be small in relation to the saturated thickness of the aquifer. Although most of the assumptions are not precisely met, the field conditions in the study area approximate most of the assumptions and the calculated hydraulic conductivities are reasonable estimates.

A computer program was used to solve equation 1 for transmissivity $(T)$ using Newton's iterative method (Carnahan and others, 1969). The difference in computed transmissivity between using storage coefficient values of 0.1 and 0.0001 is a factor of only about 2 . Horizontal hydraulic conductivity $\left(K_{h}\right)$ was then calculated using:

$$
K_{h}=\frac{T}{b}
$$

where

$$
\begin{gathered}
\mathrm{K}_{\mathrm{h}} \quad \text { horizontal hydraulic conductivity of the } \\
\text { geologic material in the vicinity of the well } \\
\text { opening, in feet per day; and } \\
\text { b thickness of the geologic material, in feet, } \\
\text { approximated using the length of the open } \\
\text { interval as reported in the drillers' report. }
\end{gathered}
$$

The use of the length of a well's open interval for b may overestimate values of $\mathrm{K}_{\mathrm{h}}$ because the equation assumes that all water flows horizontally within a layer of this thickness. Although some of the flow will be outside this region, the amount can be expected to be small (for short-duration pumping events) because in most sedimentary deposits, vertical flow is inhibited by horizontal layering.

For data from wells having only an open-ended well casing rather than a screened or perforated interval, a second equation was used to estimate hydraulic conductivities. Bear (1979) provides an equation for hemispherical flow to an open-ended well just penetrating a hydrogeologic unit. When modified for spherical flow to an open-ended well within a unit, the equation becomes

$$
K_{h}=\frac{Q}{4 \pi s r}
$$

Equation 3 is based on the assumption that vertical and horizontal hydraulic conductivities are equal, which likely is not true for the deposits in the study area. Typically, vertical hydraulic conductivities are lower than horizontal; thus, results from equation 3 likely underestimate $K_{h}$ by an unknown amount. 
Estimates of horizontal hydraulic conductivities were compiled for wells with available specific-capacity data, and statistical summaries were prepared by hydrogeologic unit (table 3). Median values of hydraulic conductivity for the aquifers (AL1, $350 \mathrm{ft} / \mathrm{d}$; AL2, $297 \mathrm{ft} / \mathrm{d} ; \mathrm{A} 1,236 \mathrm{ft} / \mathrm{d}$; A3, $176 \mathrm{ft} / \mathrm{d}$; C, $118 \mathrm{ft} / \mathrm{d}$; E, $51 \mathrm{ft} / \mathrm{d}$; and G, $34 \mathrm{ft} / \mathrm{d}$ ) are similar in magnitude to values compiled by Vaccaro and others (1998) and Savoca and others (2010) for the Puget Sound lowlands and within the range of typical hydraulic conductivity values reported by Freeze and Cherry (1979) for similar materials. Median values of estimated hydraulic conductivities for the confining units (MFL, 2,255 ft/d; A2, $49 \mathrm{ft} / \mathrm{d}$; B, $419 \mathrm{ft} / \mathrm{d}$; $\mathrm{D}, 57 \mathrm{ft} / \mathrm{d}$; and F, $9 \mathrm{ft} / \mathrm{d}$ ) and the bedrock unit ( $3 \mathrm{ft} / \mathrm{d}$ ) are higher than is typical for most of the material in these units because data for confining units are usually from wells that are preferentially open to lenses of coarse water-bearing material, or in the case of bedrock, where water-bearing fractures are present. As a result, the data are biased toward the more productive zones in these units and are not representative of the entire unit.

Estimates of horizontal hydraulic conductivity also were compiled from aquifer tests conducted by environmental consulting firms, and statistical summaries of these data were prepared by hydrogeologic unit (table 3). Aquifer tests data were only available for public-supply wells and are biased toward the major water-producing aquifers in the study area. Aquifer tests data were not available for the A1 aquifer, the MFL, A2, D, and F confining units, or bedrock unit. Median values of horizontal hydraulic conductivity for aquifer units A3, C, E, and G are within an order of magnitude of estimates for these units derived from specific capacity data (table 3) and values reported by Savoca and others (2010). Median values of horizontal hydraulic conductivity for aquifer units AL1 and AL2 (7,221 and 2,010 ft/d, respectively) are significantly higher (greater than an order of magnitude) than estimates for these units derived from specific capacity data (table 3) and values reported for the AL unit by Savoca and others (2010). However, median values for the AL1 and AL2 units are within an order of magnitude of the maximum values derived from specific capacity data (table 3 ) and the maximum value for the AL unit by Savoca and others (2010). Possible factors that may contribute to observed differences in conductivity derived from specific capacity data and aquifer tests may include differences in sample size (fewer wells with available aquifer tests) and the increased probability of encountering highly conductive zones during aquifer testing, as larger contributing volumes of aquifer material are captured as a result of higher pumping rates and longer pumping times.

Table 3. Summary of hydraulic conductivity values estimated from specific-capacity data and aquifers tests, by hydrogeologic unit, Puyallup River Watershed and vicinity, Washington.

\begin{tabular}{|c|c|c|c|c|}
\hline \multirow{2}{*}{ Hydrogeologic unit } & \multirow{2}{*}{$\begin{array}{l}\text { Number } \\
\text { of wells }\end{array}$} & \multicolumn{3}{|c|}{$\begin{array}{l}\text { Hydraulic conductivity } \\
\text { (feet per day) }\end{array}$} \\
\hline & & Minimum & Median & Maximum \\
\hline \multicolumn{5}{|c|}{ Estimated from specific-capacity data } \\
\hline AL1 alluvial aquifer & 11 & $<1$ & 350 & 1,588 \\
\hline MFL confining unit & 2 & 266 & ${ }^{1} 2,255$ & 4,244 \\
\hline AL2 alluvial aquifer & 16 & 54 & 297 & 4,534 \\
\hline A1 aquifer & 7 & 92 & 236 & 2,817 \\
\hline A 2 confining unit & 5 & $<1$ & 49 & 909 \\
\hline A3 aquifer & 58 & $<1$ & 176 & 7,110 \\
\hline B confining unit & 5 & 28 & 419 & 2,451 \\
\hline $\mathrm{C}$ aquifer & 75 & $<1$ & 118 & 7,676 \\
\hline D confining unit & 4 & 10 & 57 & 281 \\
\hline E aquifer & 30 & $<1$ & 51 & 1,016 \\
\hline F confining unit & 1 & - & 29 & - \\
\hline G undifferentiated deposits & 14 & 9 & 34 & 347 \\
\hline Bedrock unit & 3 & 3 & 3 & 5 \\
\hline \multicolumn{5}{|c|}{ Estimated from aquifer tests } \\
\hline AL1 alluvial aquifer & 1 & - & 27,221 & - \\
\hline AL2 alluvial aquifer & 6 & 268 & 2,010 & 10,273 \\
\hline A3 aquifer & 4 & 31 & 112 & 2,680 \\
\hline B confining unit & 1 & - & 224 & - \\
\hline $\mathrm{C}$ aquifer & 3 & 19 & 130 & 268 \\
\hline E aquifer & 4 & 109 & 328 & 836 \\
\hline G undifferentiated deposits & 1 & - & 219 & - \\
\hline
\end{tabular}

${ }^{1}$ Hydraulic conductivity estimate computed as average value and reported as median value.

${ }^{2}$ Hydraulic conductivity estimate for single value reported as median value. 


\section{Groundwater Movement}

This section describes the movement of groundwater in the aquifer system in the study area, and includes discussions of groundwater recharge, flow direction, discharge to surface water, exchange of water between the aquifer system and streams, and temporal fluctuations in groundwater levels. These processes occur within the physical domain described by the hydrogeologic framework and are influenced by the hydrogeologic characteristics of the aquifer system in which they occur, and by other factors, including streamflow and the spatial distribution of precipitation and land cover.

\section{Recharge}

Precipitation is the dominant source of water recharging the groundwater-flow system in the study area, and it is reasonable to expect groundwater recharge to vary with precipitation. Factors such as the permeability of surficial hydrogeologic units and land-cover characteristics also affect recharge; therefore, the relation between precipitation and recharge also depends on hydrogeologic and land-cover characteristics. The distribution of recharge from precipitation in the water-budget area was estimated by applying precipitation-recharge relations based on regression equations developed for areas in Washington State by Bidlake and Payne (2001) that incorporate the effects of surficial characteristics.

Mean annual precipitation totals (January 1, 2011December 31, 2012) were calculated from daily values obtained from the National Oceanic and Atmospheric Administration-National Climate Data Center (NOAA-NCDC; National Oceanic and Atmospheric Administration, 2013) for seven active National Weather Service (NWS) stations in the vicinity of the study area (fig. 15): Buckley 1 NE (NWS station 450945), Palmer 3 ESE (NWS station 456295), Mud Mountain Dam (NWS station 455704), Landsburg (NWS station 454486), McMillin Reservoir (NWS station 455224) Tacoma Narrows (NWS station 94274; not shown in figure 15), and Tacoma \#1 (NWS station 458278). These point data were extrapolated across the study area (fig. 15) based on the spatial distribution of normal precipitation (average annual precipitation for 1981-2010) generated from the computer program Parameter-elevation Regressions on Independent Slopes Model (PRISM) (Daly and others, 1994; PRISM Climate Group, 2014). The PRISM model estimates the distribution of normal precipitation based on a statistical method that takes into account land-surface altitude and spatial variation.

Normal precipitation at each NWS station was obtained by sampling the PRISM distribution at the seven station locations and checking against NOAA-NCDC data, allowing the PRISM distribution to be scaled for extrapolation. The normal precipitation $\left(P_{\text {normal }}\right)$ was compared to the annual precipitation ( $P_{\text {actual }}$; January 1, 2011, to December 31, 2012) at the NWS stations and a regression equation was developed for the seven points:

$$
\mathrm{P}_{\text {actual }}=2.4466 \mathrm{in} / \mathrm{yr}+1.0785 \times \mathrm{P}_{\text {normal }}
$$

This relation has a correlation coefficient of $R^{2}=0.976$ and was used to estimate the distribution of mean annual precipitation (January 1, 2011-December 31, 2012) within the water-budget area (fig. 15), based on the PRISM distribution of normal precipitation. The water-budget area received an average (January 1, 2011-December 31, 2012) of about $1,428,000$ acre-ft or about 52 in. of precipitation a year.

The effects of surficial hydrogeology on recharge from precipitation (fig. 16) were estimated using regression equations developed by Bidlake and Payne (2001) for soils in western Washington. Recharge estimates for aquifer units (outwash and alluvium) exposed at land surface in the water-budget area were calculated using regression equation developed for soils formed on glacial outwash and alluvial sediments. Recharge estimates for confining units (till, mudflow, and lacustrine) at land surface were calculated using regression equation developed for soils formed on glacial till, poorly sorted mudflow, and fine-grained lacustrine sediments.

The effect of evaporative loss on recharge from the interception of precipitation by tree canopy was estimated for aquifers using equations from Bidlake and Payne (2001). Tree canopy distribution data were obtained from the 2011 National Land Cover Database (NLCD, Jin and others, 2013). Interception loss was applied only to areas with more than 50 percent tree canopy (fig. 15).

Estimates of groundwater recharge from precipitation using equations from Bidlake and Payne (2001) are based on downward flow at a reference level within the unsaturated zone that is below the root zone, and recharge estimates do not directly account for potential plant uptake from transpiration. Urban centers in the study area manage storm water by discharging runoff either to dry wells or other structures (such as rain gardens and biofiltration swales) that promote the infiltration of this water into the groundwater-flow system, to streams, or directly to Puget Sound in areas where soils are incapable of receiving the extra water. Therefore, recharge through confining units (such as A2, MFL, and B) at land surface was reduced by one-half according to the method of Bidlake and Payne (2001) where the percentage of impervious surface in urban areas was greater than 50 percent (fig. 15) as derived from the 2011 NLCD (Jin and others, 2013). No direct recharge from precipitation was assumed for areas covered by lakes or where bedrock was exposed at land surface. 


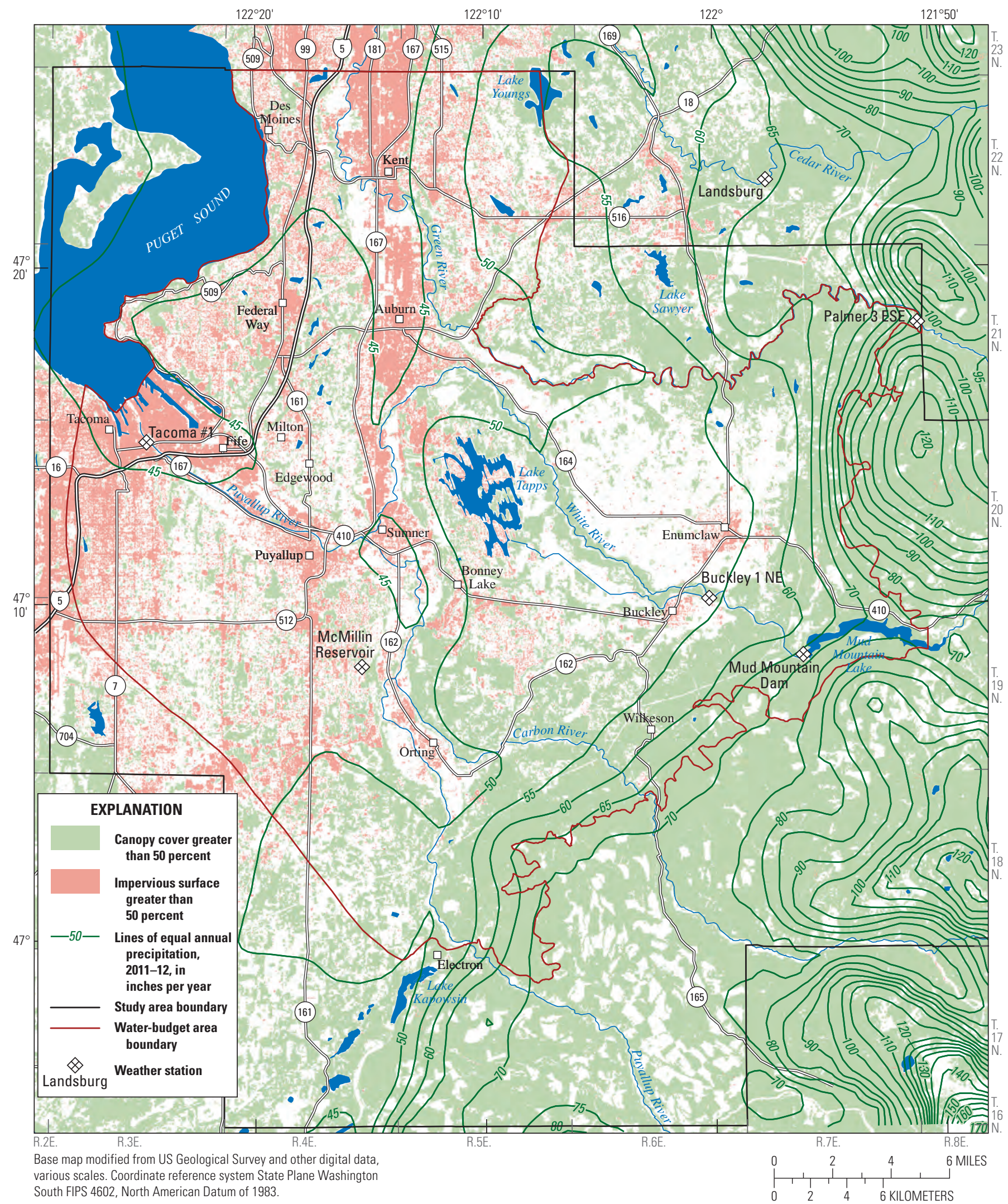

Figure 15. Average annual precipitation, canopy cover, and impervious surface across the Puyallup River Watershed and vicinity, Washington, January 2011-December 2012. 


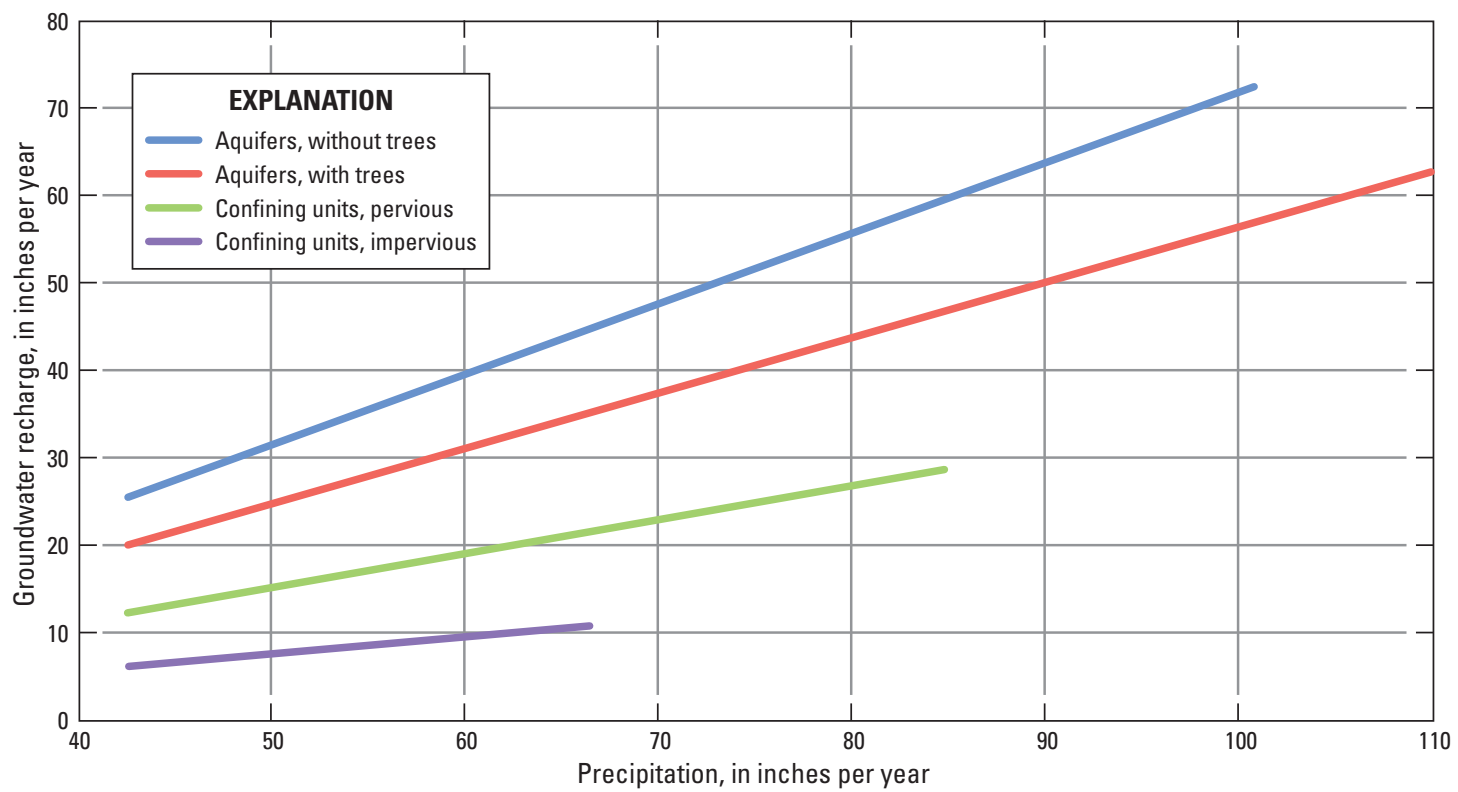

Figure 16. Precipitation-recharge relations used in this study, Puyallup River Watershed and vicinity, Washington.

GIS techniques were used to combine the data coverages described in the previous paragraphs and calculate the distribution of groundwater recharge from precipitation in the water-budget area (fig. 17). Recharge rates ranged from about $6 \mathrm{in} / \mathrm{yr}$ in urban areas (greater than 50 percent impervious surface) underlain by confining units to more than $65 \mathrm{in} / \mathrm{yr}$ in areas underlain by permeable aquifer deposits with less than 50 percent tree canopy in mountainous terrain $(1,500-2,300 \mathrm{ft}$ altitude) along the eastern margin of the water-budget area where precipitation locally exceeds $90 \mathrm{in} / \mathrm{yr}$. Summing the recharge areas shown in figure 17 indicates that the groundwater-flow system within the water-budget area received an annual average (January 1, 2011, to December 31, 2012) of about 580,600 acre-ft or about 21 in. of recharge from precipitation, equivalent to approximately 41 percent of the total precipitation.

Both the spatial distribution and the annual amounts of recharge estimated for this study are similar to estimates made by Vaccaro and others (1998; 1 to more than $50 \mathrm{in} / \mathrm{yr}$ ) in an assessment of the Puget Sound Regional Aquifer System. Recharge estimates used in other investigations for glacial outwash and till mantled areas in the Puget Sound region (Turney and others, 1995; Drost and others, 1999; van Heeswijk and Smith, 2002; Savoca and others, 2010) also are similar to the estimates used in this study, and range from 4 to $70 \mathrm{in} / \mathrm{yr}$.

In addition to groundwater recharge from precipitation, groundwater recharge from streams also occurs in the study area along losing stream reaches. The total amount of groundwater recharge from streams is not quantified here, but is reflected in the computation of the total net groundwater discharge to streams presented in the water budget. Losing stream reaches and estimates of stream losses are presented in section, "Groundwater and Surface-Water Interactions." The net exchange of groundwater and surface water in the study area is dominated by groundwater discharge to streams, and most stream reaches in the study area either gain flow from groundwater discharge or exhibit near-neutral conditions with no substantial gain or loss of flow. Groundwater recharge from lakes also occurs in the study area and may locally provide significant recharge to the groundwater system. The total amount of groundwater recharge from lakes is not quantified here, but will be simulated during development of a numerical flow model of the groundwater-flow system in the study area.

\section{Groundwater-Flow Directions}

The generalized direction of horizontal groundwater movement was inferred from maps of water-level altitude contours. Groundwater generally moves from areas of recharge to areas of discharge in the direction of decreasing waterlevel altitudes and is perpendicular to the water-level altitude contours. Groundwater levels measured during operation of the monthly monitoring network (March 2011-March 2013) were used to evaluate groundwater-flow directions in aquifers within the study area (figs. 18-24). The mean water-level value for the period of record was used to represent the water-level altitude at monthly monitoring wells for this analysis to represent average annual conditions, and more closely correlate with other average annual water-budget components, such as recharge and well withdrawals. Synoptic measurements of groundwater levels made during the field inventory (January-February 2011) were used only in areas where monthly water-level data were not available. 


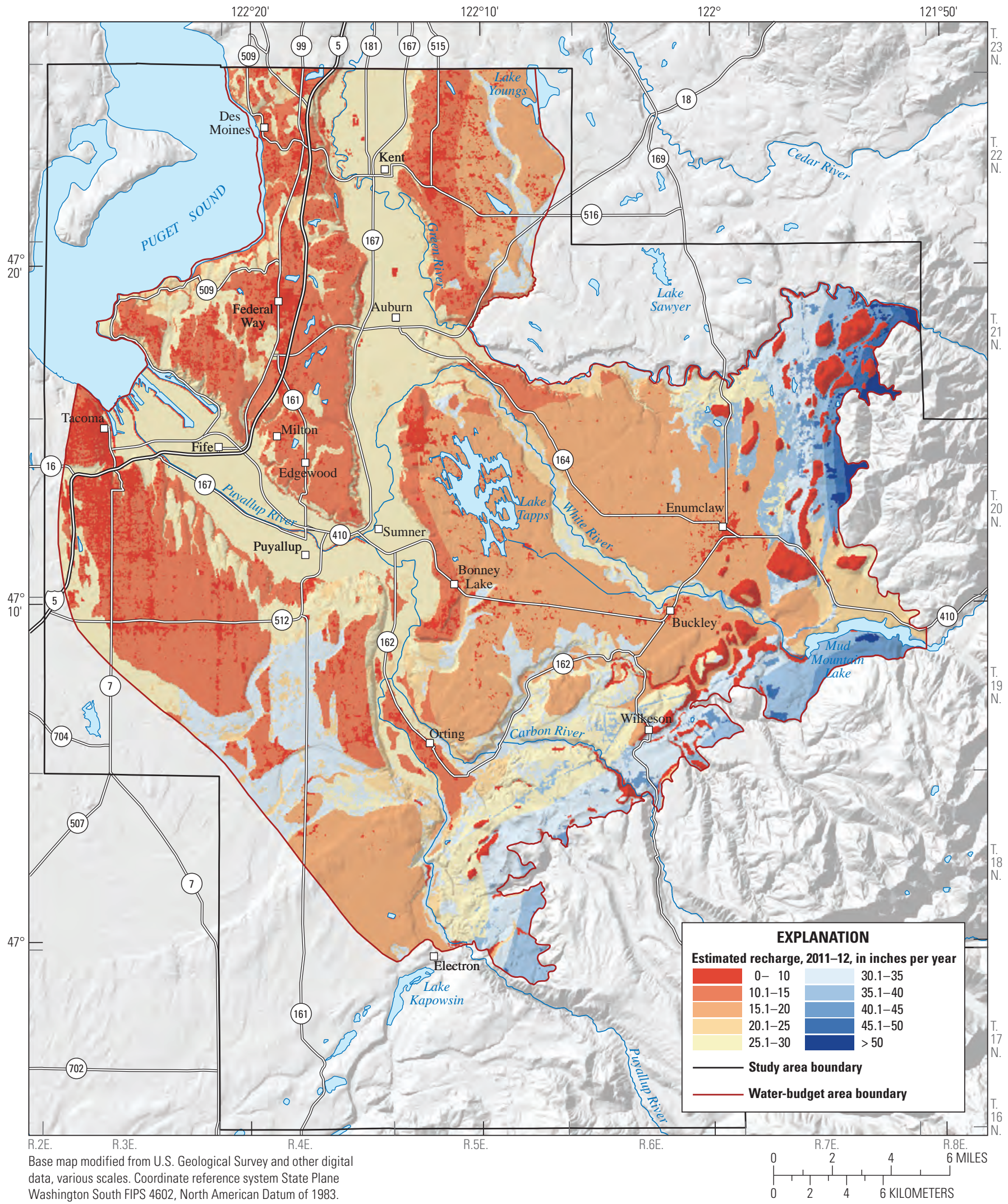

Figure 17. Distribution of average annual groundwater recharge from precipitation in Puyallup River Watershed and vicinity, Washington, January 2011-December 2012. 


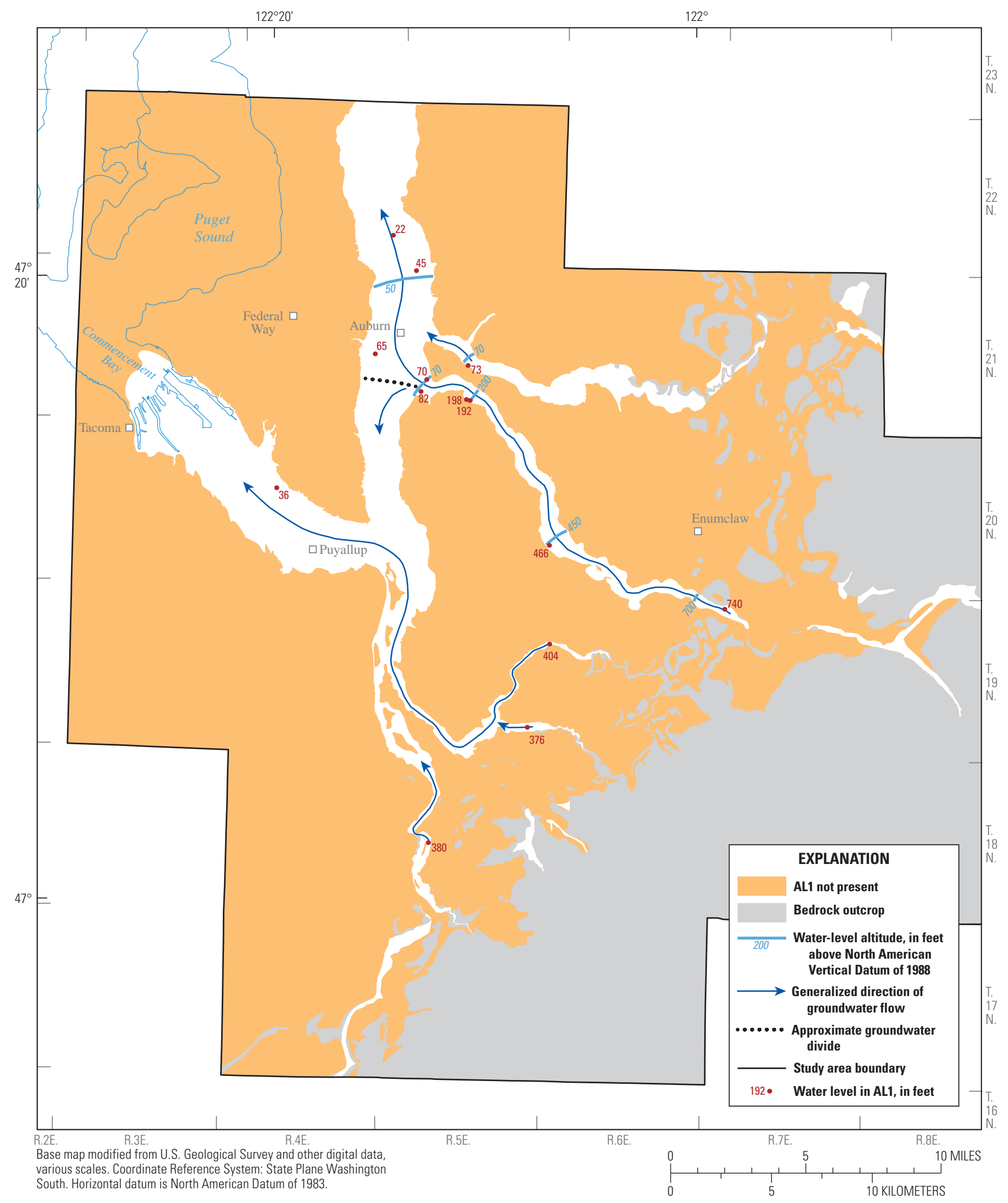

Figure 18. Water-level altitudes and direction of groundwater flow in AL1 upper alluvial aquifer, Puyallup River Watershed and vicinity, Washington, March 2011-March 2013. 


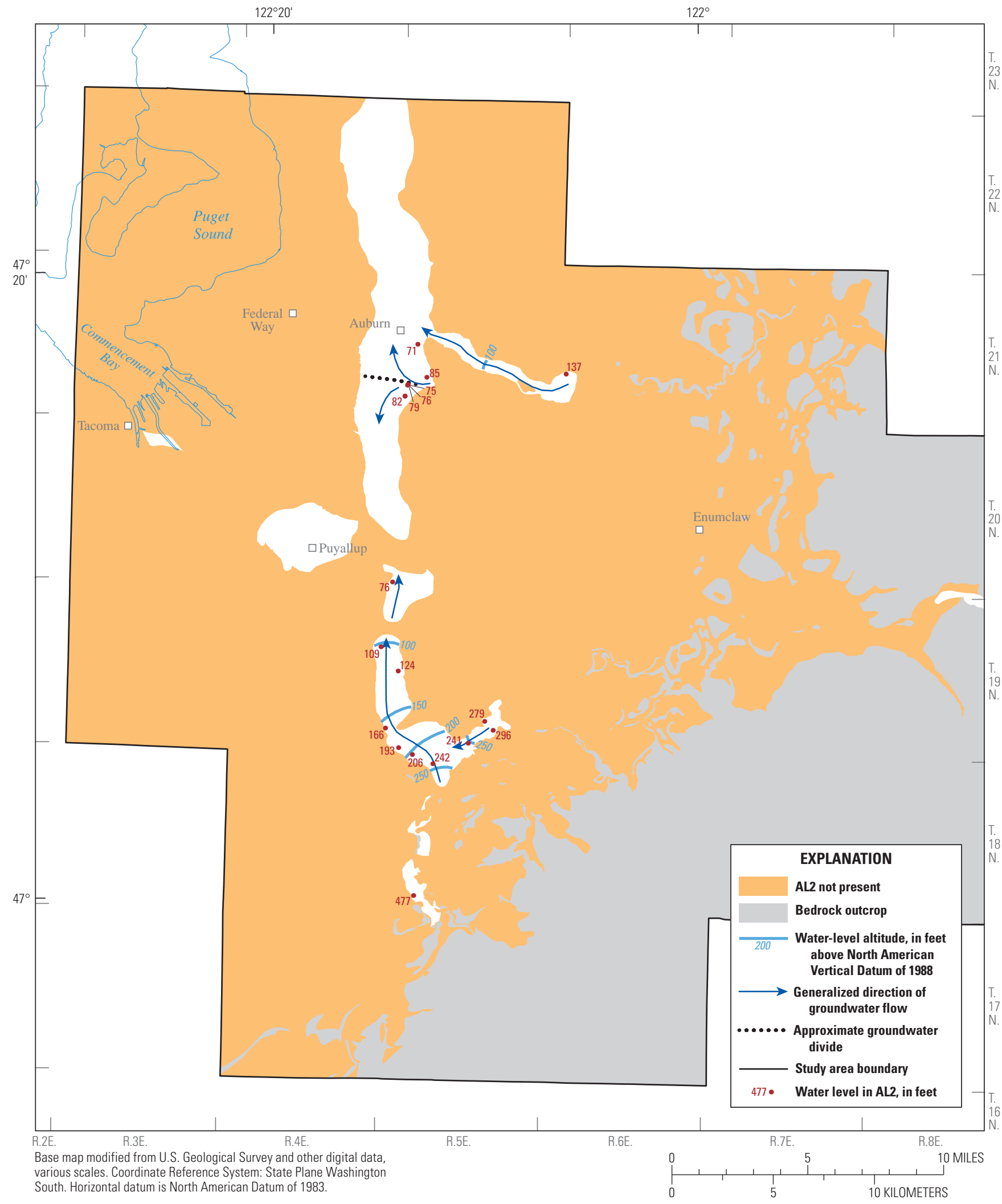

Figure 19. Water-level altitudes and direction of groundwater flow in AL2 lower alluvial aquifer, Puyallup River Watershed and vicinity, Washington, March 2011-March 2013. 


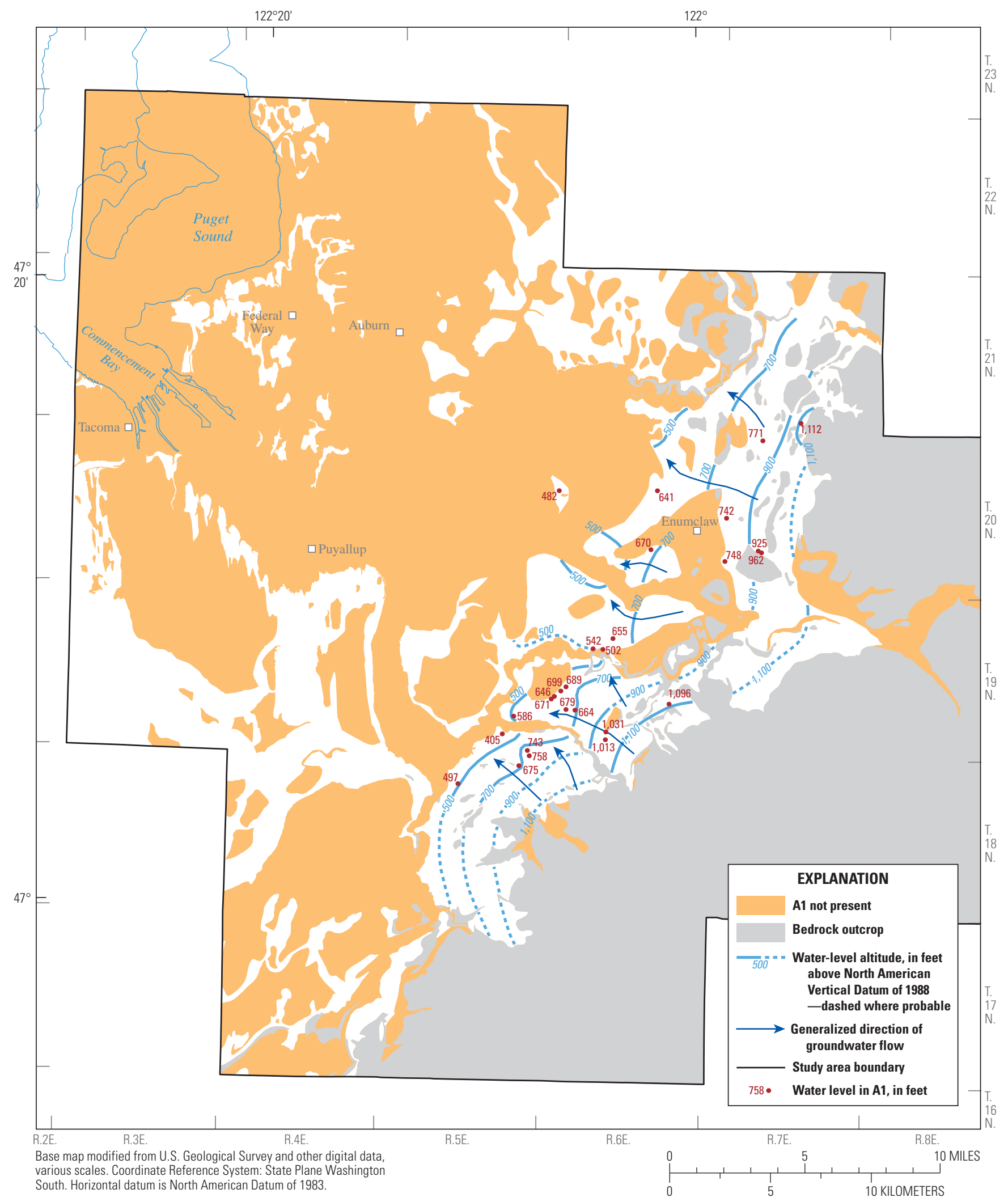

Figure 20. Water-level altitudes and direction of groundwater flow in A1 aquifer, Puyallup River Watershed and vicinity, Washington, March 2011-March 2013. 


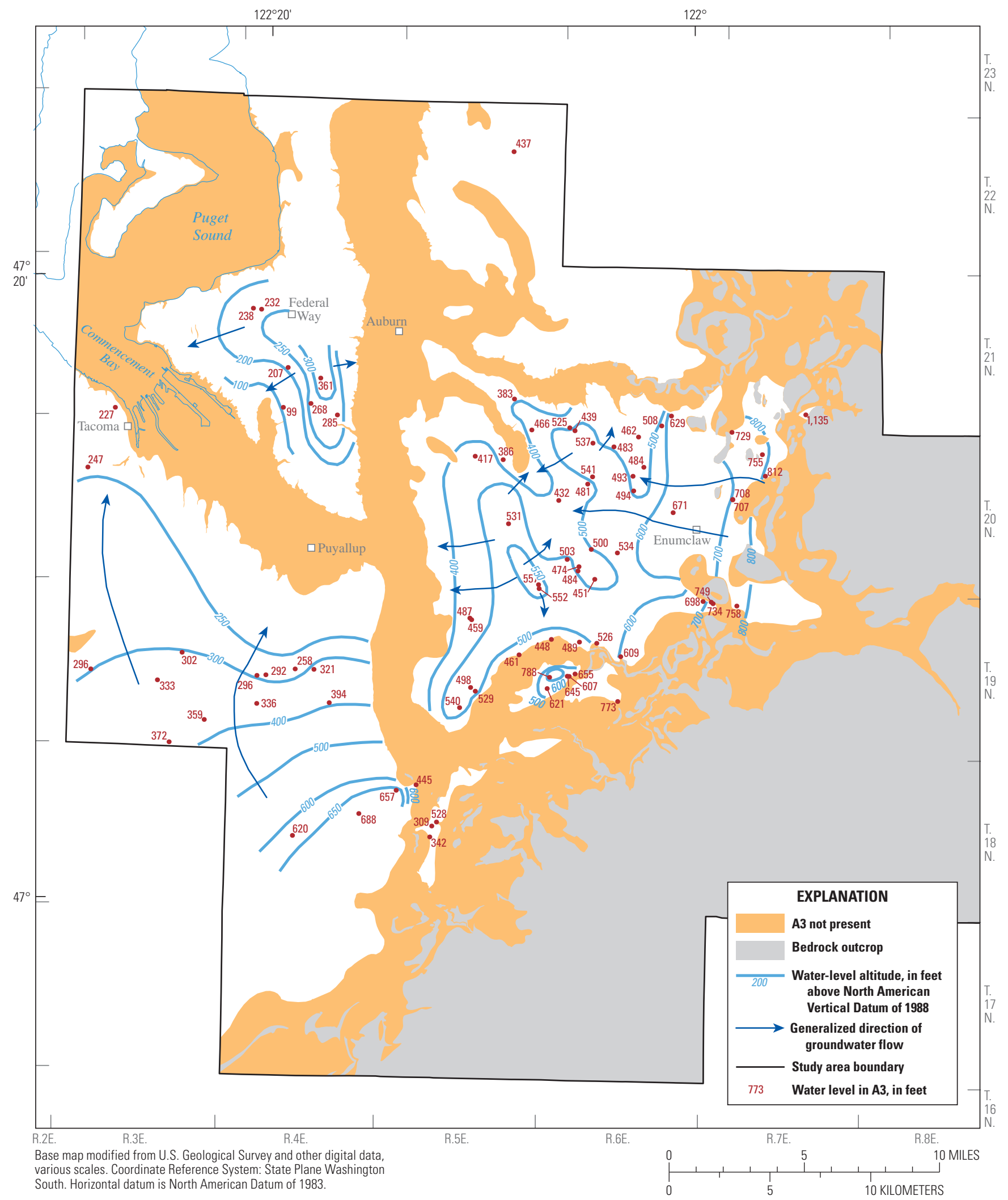

Figure 21. Water-level altitudes and direction of groundwater flow in A3 aquifer, Puyallup River Watershed and vicinity, Washington, March 2011-March 2013. 


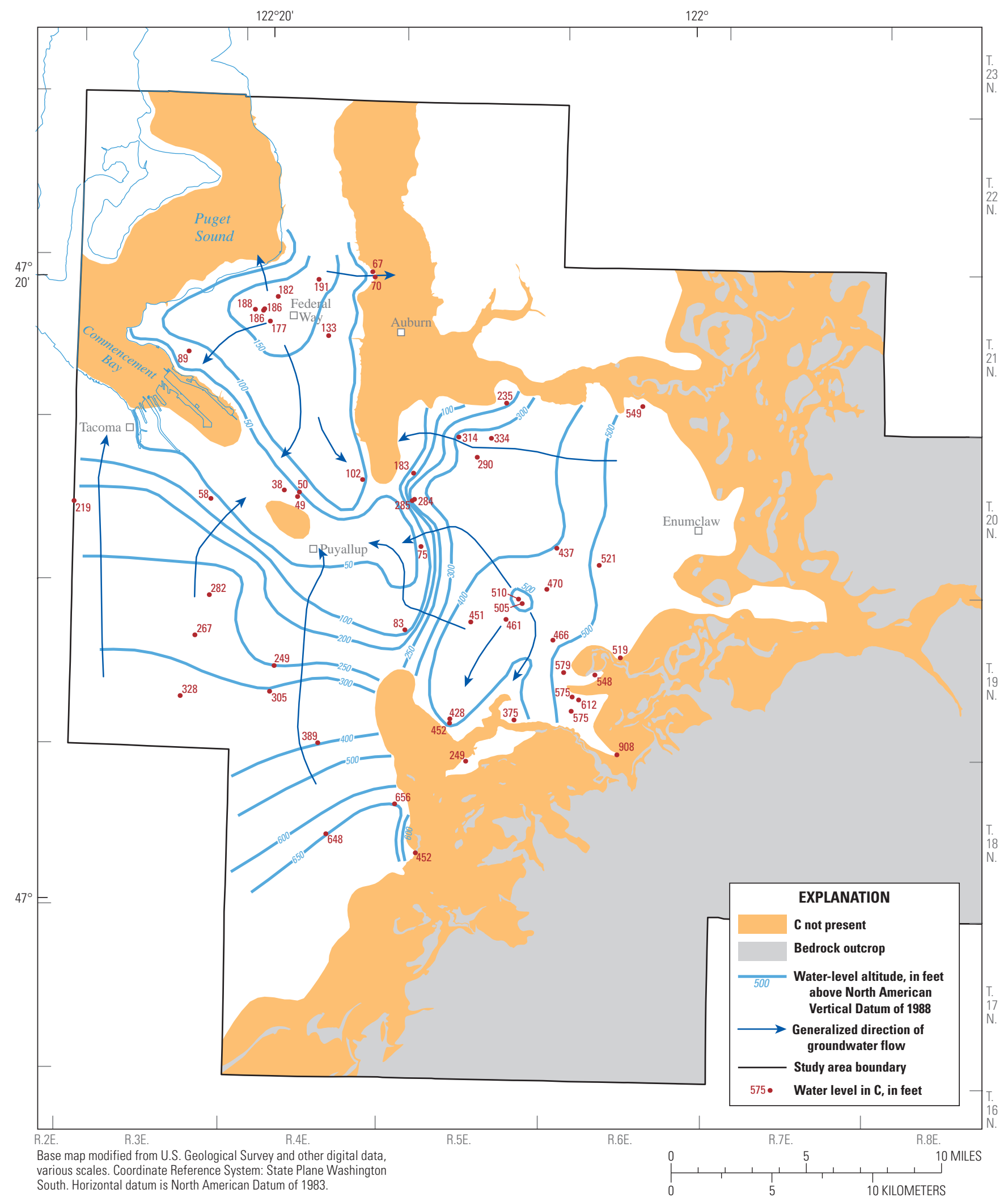

Figure 22. Water-level altitudes and direction of groundwater flow in $\mathrm{C}$ aquifer, Puyallup River Watershed and vicinity, Washington, March 2011-March 2013. 


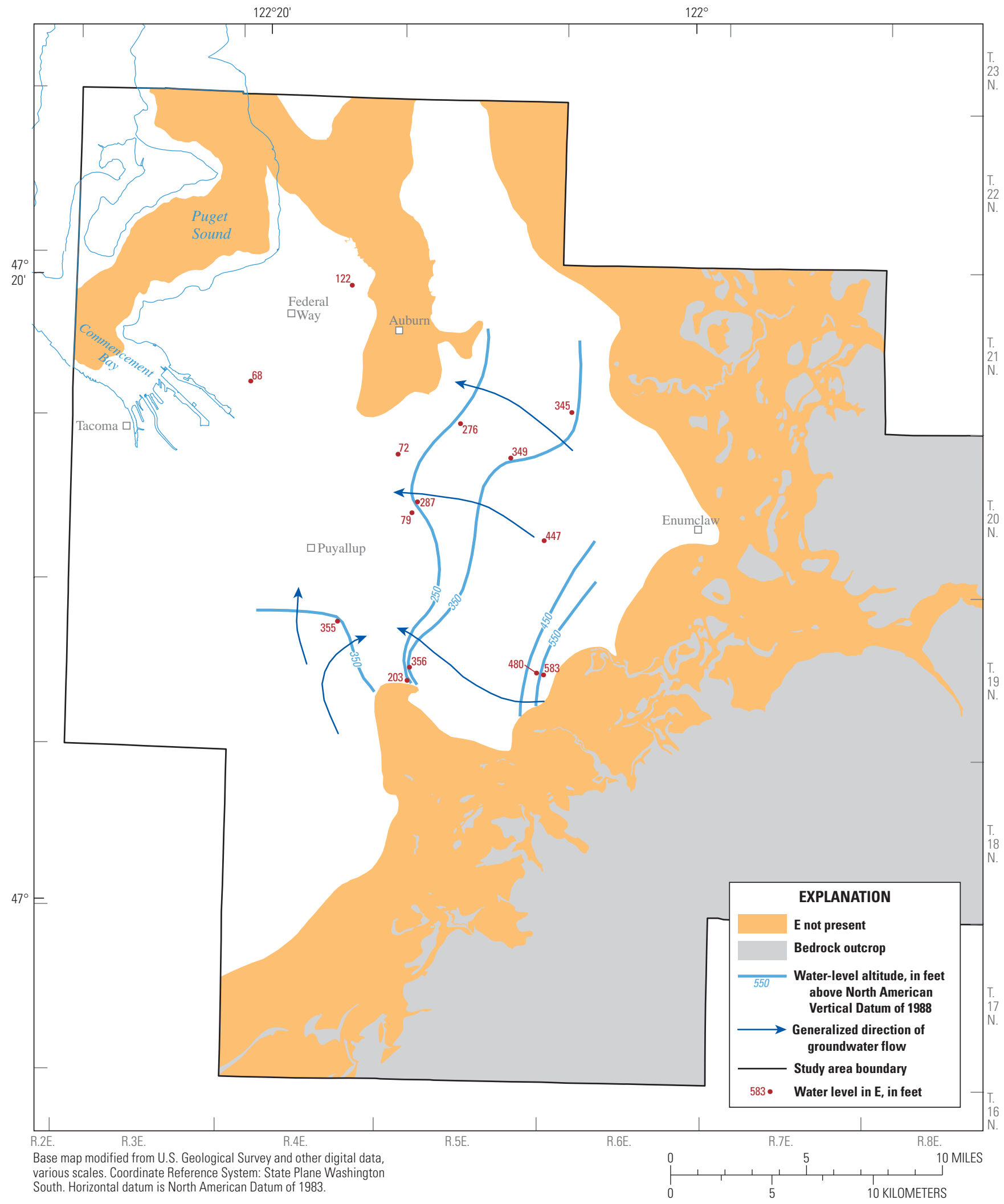

Figure 23. Water-level altitudes and direction of groundwater flow in E aquifer, Puyallup River Watershed and vicinity, Washington, March 2011-March 2013. 


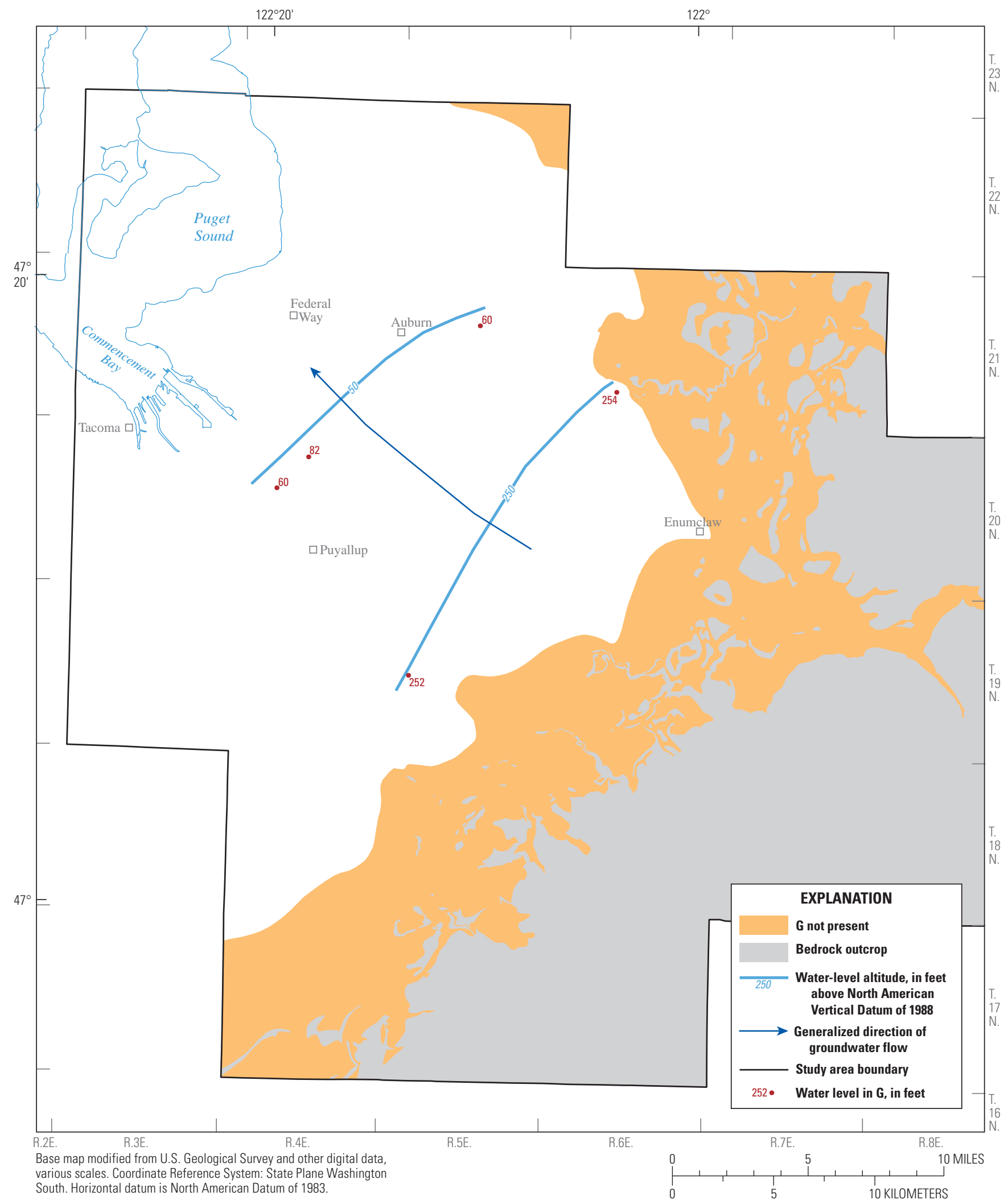

Figure 24. Water-level altitudes and direction of groundwater flow in $\mathrm{G}$ undifferentiated deposits, Puyallup River Watershed and vicinity, Washington, March 2011-March 2013. 
Water-level contours for most aquifer units are based on limited water-level data and are subject to uncertainty. For the same reason, the illustrated groundwater-flow directions for the uppermost units in particular are generalized and do not reflect local flow characteristics, such as groundwater discharge to or recharge from streams. Water-level contours were not drawn for large parts of aquifer units $\mathrm{E}$ and $\mathrm{G}$ because of a lack of data. A numerical flow model of the groundwater-flow system in the study area, currently under development, should provide additional insight into groundwater-flow directions.

Groundwater flow in the AL1 and AL2 alluvial aquifers generally is towards the north and northwest in the down-valley direction of most rivers, towards Puget Sound (figs. 18 and 19). Water-level data, and results of a study conducted by the City of Auburn (written commun., 2013), suggest the presence of a groundwater divide in the alluvial aquifers, where the White and Green Rivers enter the Auburn Valley, that separates flow to the south towards the Puyallup River and groundwater movement towards the north out of the study area to the Duwamish River.

Groundwater flow in the $\mathrm{A} 1$ and $\mathrm{A} 3$ aquifers generally is towards the northwest (figs. 20 and 21). Water-level data suggest localized groundwater flow towards major river valleys in the study area, and it is likely that $\mathrm{A} 1$ and $\mathrm{A} 3$ aquifers locally contribute groundwater discharge to rivers in the study area along valley margins. Water-level data within upland areas southwest of the Puyallup River valley suggest the presence of divergent groundwater flow (northeastern and northwestern flow directions) in the A3 aquifer that generally coincides with the eastern portion of a previously delineated regional groundwater divide (Savoca and others, 2010; Johnson and others, 2011). Other groundwater-flow features indicated by water levels in the A3 aquifer include a partially delineated groundwater high and radial flow within the upland area separating the northern Puyallup River and southern Auburn Valleys, and radial flow off a groundwater high within the upland area between the Puyallup River, Carbon River, and White River valleys.

Groundwater flow in the $\mathrm{C}$ aquifer is generally towards the north and northwest (fig. 22) except in the upland area separating the northern Puyallup River and southern Auburn Valleys. Water-level data suggest localized groundwater flow towards major river valleys in the study area; and the $\mathrm{C}$ aquifer likely contributes groundwater discharge to rivers in the study area along valley margins, and locally within river valley bottoms. Water-level data in upland areas southwest of the Puyallup River valley indicate a pattern of divergent groundwater flow (northeastward and northward flow directions) in the $\mathrm{C}$ aquifer that is similar to the groundwater divide delineated in the $\mathrm{A} 3$ aquifer, and generally coincides with the eastern portion of a previously delineated regional groundwater divide (Savoca and others, 2010; Johnson and others, 2011). Water-level data in the $\mathrm{C}$ aquifer indicate radial flow off a groundwater high within the upland area separating the northern Puyallup River and southern Auburn Valleys.
Northwestward groundwater flow in the E aquifer is inferred from widely spaced water-level data in the central part of the study area (fig. 23). Water-level data from five wells in the $G$ undifferentiated deposits suggest that northwestward groundwater flow is likely in the central part of the study area (fig. 24).

The potential for vertical flow between aquifers is difficult to determine because extents and thicknesses of hydrogeologic units vary considerably throughout the study area, the presence of confining layers within and between aquifers is highly variable, and the data available for comparing water levels between adjacent units are widely spaced. Water-level differences between the AL1 and AL2 alluvial aquifers (figs. 18 and 19) indicate the potential for upward groundwater flow where the White and Green Rivers enter the Auburn Valley in the north-central part of the study area, and flowing wells at two locations in the AL2 lower alluvial aquifer near the confluence of the Puyallup and Carbon Rivers also suggest a potential upward vertical gradient. Water-level differences between the A1 and A3 aquifers (figs. 20 and 21) indicate the potential for downward groundwater flow in east-central and central parts of the study area (adjacent to the mountain front, and within upland areas between the White and Green Rivers, respectively). Waterlevel differences between the $\mathrm{A} 3$ and $\mathrm{C}$ aquifers (figs. 21 and 22) show the potential for downward vertical flow throughout much of the study area where both units are present. Flowing wells at three locations (20N/04E-14B01, 20N/04E-16L01, and 20N/04E-16L02) in the C aquifer along the margins of the Puyallup River and Auburn Valleys in the west-central part of the study area indicate upward vertical gradients and groundwater flow from the $\mathrm{C}$ aquifer to overlying alluvial sediments. A comparison of water levels between the $\mathrm{C}$ and $\mathrm{E}$ aquifers is difficult because of the significantly fewer and widely spaced water levels in the $\mathrm{E}$ aquifer. Small differences at locations where water levels in the $\mathrm{C}$ and $\mathrm{E}$ aquifers are relatively close suggest little in the way of vertical flow potential between the aquifers (figs. 22 and 23). A flowing well (20N/04E-17G01) in G undifferentiated deposits located upstream of the mouth of the Puyallup River indicates the potential for upward groundwater flow (fig. 24).

\section{Discharge}

Groundwater in the study area discharges as seepage to streams, lakes, springs, marshes, and coastal bluffs; as evaporation and transpiration of shallow groundwater; as submarine seepage to Puget Sound; and as withdrawals from wells. Estimates of groundwater discharge to streams (baseflow) in the study area were based on synoptic streamflow measurements taken in October 2011 and October 2012 at eight locations near the outlets of the major streams draining the study area (table 4 and pl. 1). 
Table 4. Estimates of groundwater discharge to streams (baseflow) draining the Puyallup River Watershed and vicinity, Washington, October 2011 and October 2012.

[M easurement site and site No.: Name and location of sites shown on late 4. Discharge rating: Accuracy rating of U.S. Geological Survey measurements: G, good; F, fair; P, poor; -, no rating; estimated values are rated poor. A bbreviations: $\mathrm{ft}^{3} / \mathrm{s}$, cubic feet per second]

\begin{tabular}{|c|c|c|c|}
\hline $\begin{array}{l}\text { Measurement site } \\
\text { and site No. }\end{array}$ & $\begin{array}{l}\text { Date discharge } \\
\text { measured }\end{array}$ & $\begin{array}{l}\text { Estimated groundwater } \\
\text { discharge }\left(\mathrm{ft}^{3} / \mathrm{s}\right) \text { to } \\
\text { streams (baseflow) }\end{array}$ & $\begin{array}{l}\text { Discharge } \\
\text { rating }\end{array}$ \\
\hline \multirow[t]{2}{*}{ Green River at 200th Street at Kent (12113344) } & $10-17-11$ & 1,2,386.8 & $\mathrm{P}$ \\
\hline & $10-11-12$ & ${ }^{1,3} 67.8$ & $\mathrm{P}$ \\
\hline \multirow[t]{2}{*}{ Cold Creek near mouth at Poverty Bay } & $10-05-11$ & ${ }^{4} 0.94$ & $\mathrm{~F}$ \\
\hline & $10-05-12$ & ${ }^{4} 1.09$ & $\mathrm{~F}$ \\
\hline \multirow[t]{2}{*}{ Lakota Creek near mouth at Poverty Bay } & $10-05-11$ & ${ }^{4} 1.62$ & $\mathrm{~F}$ \\
\hline & $10-05-12$ & ${ }^{4} 1.28$ & $\mathrm{~F}$ \\
\hline \multirow[t]{2}{*}{ Hylebos Creek near Milton } & $10-05-11$ & ${ }^{4} 3.44$ & $\mathrm{~F}$ \\
\hline & $10-05-12$ & ${ }^{4} 3.31$ & $\mathrm{~F}$ \\
\hline \multirow[t]{2}{*}{ Des Moines Creek below SR 509 near mouth } & $10-05-11$ & ${ }^{5} 2.00$ & - \\
\hline & $10-05-12$ & ${ }^{5} 3.51$ & - \\
\hline \multirow[t]{2}{*}{ Puyallup River at Puyallup (12101500) } & $10-18-11$ & 1,3311 & G \\
\hline & $10-11-12$ & 1,3235 & G \\
\hline \multirow[t]{2}{*}{ Clarks Creek at Stewart Avenue near Puyallup (12102060) } & $10-17-11$ & 59.2 & G \\
\hline & $10-11-12$ & 54.9 & $\mathrm{G}$ \\
\hline \multirow[t]{2}{*}{ Clear Creek at 31st Avenue Ct. East Tacoma (12102175) } & $10-17-11$ & 14.3 & $\mathrm{P}$ \\
\hline & $10-11-12$ & 16.3 & $\mathrm{P}$ \\
\hline \multirow[t]{2}{*}{ Swan Creek at Pioneer Way Tacoma (12102212) } & $10-17-11$ & 2.87 & $\mathrm{~F}$ \\
\hline & $10-11-12$ & 2.66 & $\mathrm{~F}$ \\
\hline Total estimated groundwater discharge to streams & $\begin{array}{l}\text { October } 2011 \\
\text { October } 2012\end{array}$ & 482,386 & \\
\hline \multicolumn{4}{|c|}{${ }^{1}$ Daily mean streamflow at U.S. Geological Survey streamflow-gaging stations. } \\
\hline \multicolumn{4}{|c|}{${ }^{2}$ Estimated by U.S. Geological Survey based on discharge measurements from nearby sites. } \\
\hline \multicolumn{4}{|c|}{$\begin{array}{l}{ }^{3} \text { Discharge for Green and Puyallup Rivers computed as difference between downstream and upstream discharge to account for } \\
\text { contributions to streamflow from melting snow and/or ice. Green River discharge was reduced by } 44 \text { percent based on the watershed } \\
\text { area between the upstream and downstream streamflow-gaging stations that occurs outside the Budget Area. }\end{array}$} \\
\hline \multicolumn{4}{|c|}{${ }^{4}$ Discharge measurement by Robinson Noble, Inc. (Burt Clothier, written commun., 2014). } \\
\hline
\end{tabular}

Baseflow is the major source of late-summer and early autumn flow to streams that do not also receive water from melting snow and glacial ice (such as Cold, Lakota, Hylebos, Clarks, Clear, and Swan Creeks), and synoptic streamflow measurements for these streams (table 4) likely consist primarily of baseflow.

The headwaters of other streams in the study area (such as the Green, White, Carbon, and Puyallup Rivers) originate within high elevation terrain outside of the study area, and receive water from baseflow and from melting snow and glacial ice. Daily inputs of meltwater are particularly strong through the summer and early autumn months and this diurnal flow signature can mask the effects of groundwater inflow/ outflow in a stream. Commonly used hydrograph separation methods such as HYSEP (Sloto and Crouse, 1996) and WHAT (Lim and others, 2005) are designed to separate streamflow hydrographs into baseflow and surface-runoff components, but do not address other source of streamflow such as snow and glacial ice. Digital recursive filters (Lyne and Hollick, 1979; Ekhardt 2005) have recently been used to separate streamflow hydrographs into snow and glacial ice melt and surface-runoff components, but do not include baseflow (Matthew Bachmann, U.S. Geological Survey, written commun., 2014). Cool and dry conditions in high elevations of the study area (Western Region Climate Center, 2014a) during the 2011 and 2012 synoptic measurement periods resulted in the attenuation of diurnal variations in streamflow caused by contributions to streamflow from melting snow and glacial 
ice (Ken Frasl, U.S. Geological Survey, oral commun., 2014). Snow cover in the mountains during the synoptic measurement periods were near the normal annual minimum (Western Region Climate Center, 2014b), further reducing snow melt contributions to streamflow.

It is likely that groundwater discharge was a significant portion of streamflow in the Green, White, Carbon, and Puyallup Rivers during the 2011 and 2012 synoptic measurement periods, however, quantifying baseflows to these rivers is difficult without first accounting for contributions to streamflow from melting snow and glacial ice. This was accomplished for the Green River by computing the difference between discharge near its mouth (table 5, site 12113344) and discharge along the upper portion of the river where it exits the mountains (table 5, site 12106700), resulting in an estimated total discharge for the 2011 and 2012 synoptic measurement periods of 155 and $121 \mathrm{ft}^{3} / \mathrm{s}$, respectively. Contributions to streamflow from melting snow and glacial ice were unlikely during the synoptic measurement periods at Green River Watershed downstream of site 12106700, and the difference in discharge likely primarily consists of baseflow. Total estimates of discharge were reduced by 56 percent (table 4) to approximate that portion of groundwater discharge to the Green River originating from within the water-budget area (fig. 1). A more accurate quantification of groundwater discharge to the Green River originating from within the water-budget area would require the location of groundwater divides and gradients for each of the aquifer units outside the water-budget area between the Green and Cedar Rivers, and these data are not currently available.

A similar approach was used to estimate baseflow to the Puyallup River (including its major tributaries, the Carbon and White Rivers) in which contributions to streamflow from melting snow and glacial ice were removed by computing the difference between discharge near the mouth of the Puyallup River (table 5; site 12101500) and discharge along the upper portions of the Puyallup, Carbon, and White Rivers where they exit the mountains (table 5; sites 12092505, 12094000, and 12097850 , respectively), resulting in an estimated discharge for the 2011 and 2012 synoptic measurement periods of 311 and $235 \mathrm{ft}^{3} / \mathrm{s}$, respectively (table 4).

Baseflow estimates (table 4) represent flow from contributing areas upstream of the synoptic streamflow measurement sites (398 $\left.\mathrm{mi}^{2}\right)$ and do not include contributing areas in the Puyallup and Green Rivers downstream of USGS measurement sites or groundwater discharge in areas with poorly developed surface-water drainage along the southwestern and northwestern margins of the study area $\left(122 \mathrm{mi}^{2}\right)$. A total of approximately $482 \mathrm{ft}^{3} / \mathrm{s}$ (349,000 acre-ft/yr) of groundwater discharge to streams was measured during October 2011, and approximately $386 \mathrm{ft}^{3} / \mathrm{s}$ (280,000 acre-ft/yr) of groundwater discharged to streams measured during October 2012 (table 4). These discharge estimates should be considered near-minimum values because streamflow measurements were made during the dry late-summer and early-autumn period when groundwater levels typically are at annual lows. The treatment of baseflow estimates from the October 2011 and October 2012 synoptic streamflow estimates as near-minimum values is supported by monthly mean baseflow estimates reported by Sinclair and Pitz (1999) using hydrograph separation techniques. Monthly mean baseflow was estimated by Sinclair and Pitz (1999) for three rivers where snowmelt, glacial ice melt, and reservoir releases do not contribute substantially to streamflow: Big Soos Creek (12112600), Newaukum Creek (12108500), and South Prairie Creek (12095000). At each of these locations, mean monthly baseflow is lowest during the months of August, September, and October. During wetter periods, water levels are usually higher; thus, larger quantities of groundwater likely flow to streams. In addition, many small streams were not measured, but they may collectively receive a large quantity of groundwater discharge at various times throughout the year.

Groundwater withdrawals from wells in the study area during 2012 were an estimated 42,600 acre-ft (table 6). This quantity represents gross withdrawals and does not reflect the quantity of water returned to the groundwater system through septic tanks or through irrigation return flows to shallow aquifers. Groundwater withdrawals for Group A public water-supply systems (27,500 acre-ft) were compiled from reported withdrawals (Washington State Department of Health, 2014) from 85 public water suppliers in the area, and estimated withdrawals for 18 residential public water-supply systems and mobile home parks using per capita water use rates of 88 and $70 \mathrm{gal} / \mathrm{d}$, respectively. These use rates were based on reported withdrawals from similar water supply systems in the area and service populations obtained from the WADOH public water system database (Washington State Department of Health, 2014). Groundwater withdrawals for Group B public water-supply systems (800 acre-ft) were estimated using a typical per capita water use rate of $88 \mathrm{gal} / \mathrm{d}$ based on reported withdrawals from similar water supply systems in the area and service populations obtained from the WADOH public water system database (Washington State Department of Health, 2014) for 823 Group B water suppliers in the area. Self-supplied domestic groundwater withdrawals (1,500 acre-ft) were estimated using the Group B per capita water use rate of $88 \mathrm{gal} / \mathrm{d}$ and an estimate of the self-supplied population in the area (Washington State Office of Financial Management, 2014). Other self-supplied groundwater withdrawals $(6,800$ acre-ft) that typically include activities associated with livestock production, aquaculture, industrial processes, and mining, were estimated from groundwater withdrawal and use data collected by the USGS (Lane, 2015). Groundwater withdrawals for the irrigation of agricultural crops and pastures (6,000 acre-ft) were estimated using an application rate of 1.20 acre-ft/yr (Lane, 2015) and 5,000 acres of irrigated crop and pasture lands in the area (Washington State Department of Agriculture, 2014). 
Table 5. Synoptic streamflow measurements and estimates of gains and losses in the Puyallup River Watershed and vicinity, Washington, October 2011 and October 2012.

[M easurement site and site No.: Name and location of sites shown on plate 4. Discharge rating, percent error, and error value: Accuracy rating of U.S. Geological Survey measurements: G, good; F, fair; P, poor; error value in $\mathrm{ft}^{3} / \mathrm{s}$; -, no rating; estimated values are rated poor. Measured gain or loss: Uncertainties due to measurement error were too large at some locations to make defensible conclusions regarding the characterization of gaining or losing stream reaches and those values are italicized. Abbreviations: $\mathrm{ft}^{3} / \mathrm{s}$, cubic feet per second; -, not available]

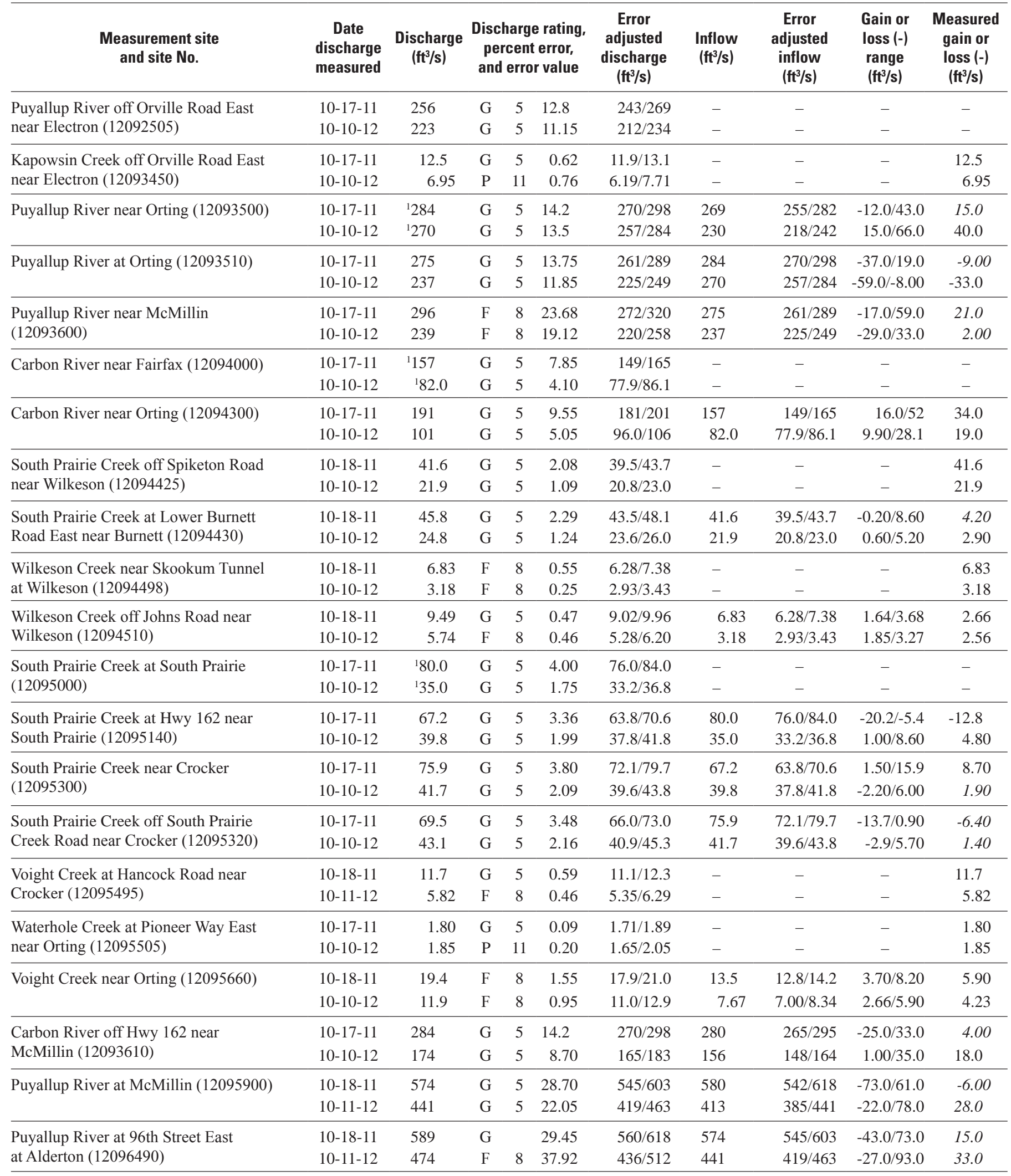


Table 5. Synoptic streamflow measurements and estimates of gains and losses in the Puyallup River Watershed and vicinity, Washington, October 2011 and October 2012.-Continued

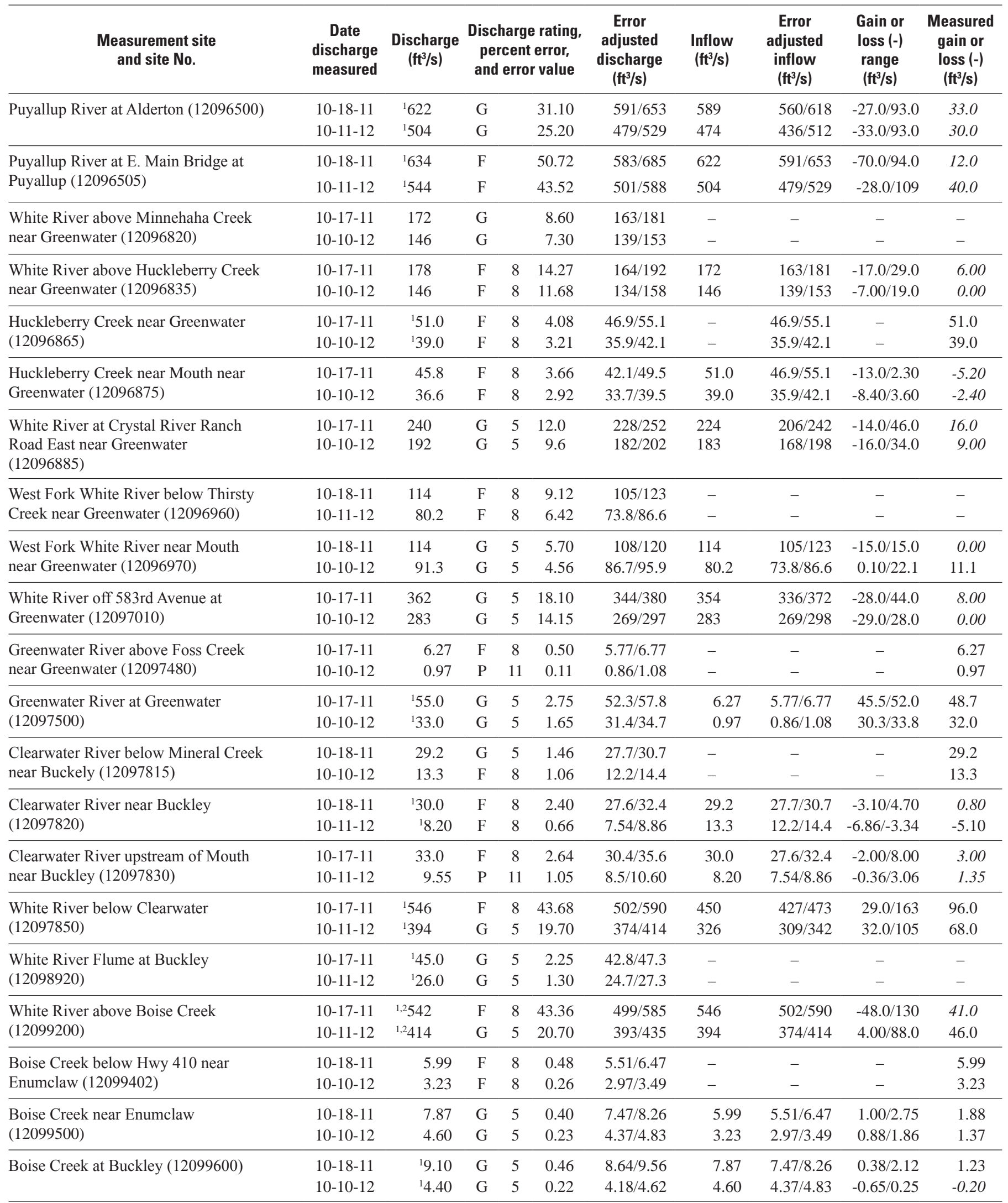




\section{Hydrogeologic Framework in the Puyallup River Watershed, Pierce and King Counties, Washington}

Table 5. Synoptic streamflow measurements and estimates of gains and losses in the Puyallup River Watershed and vicinity, Washington, October 2011 and October 2012.-Continued

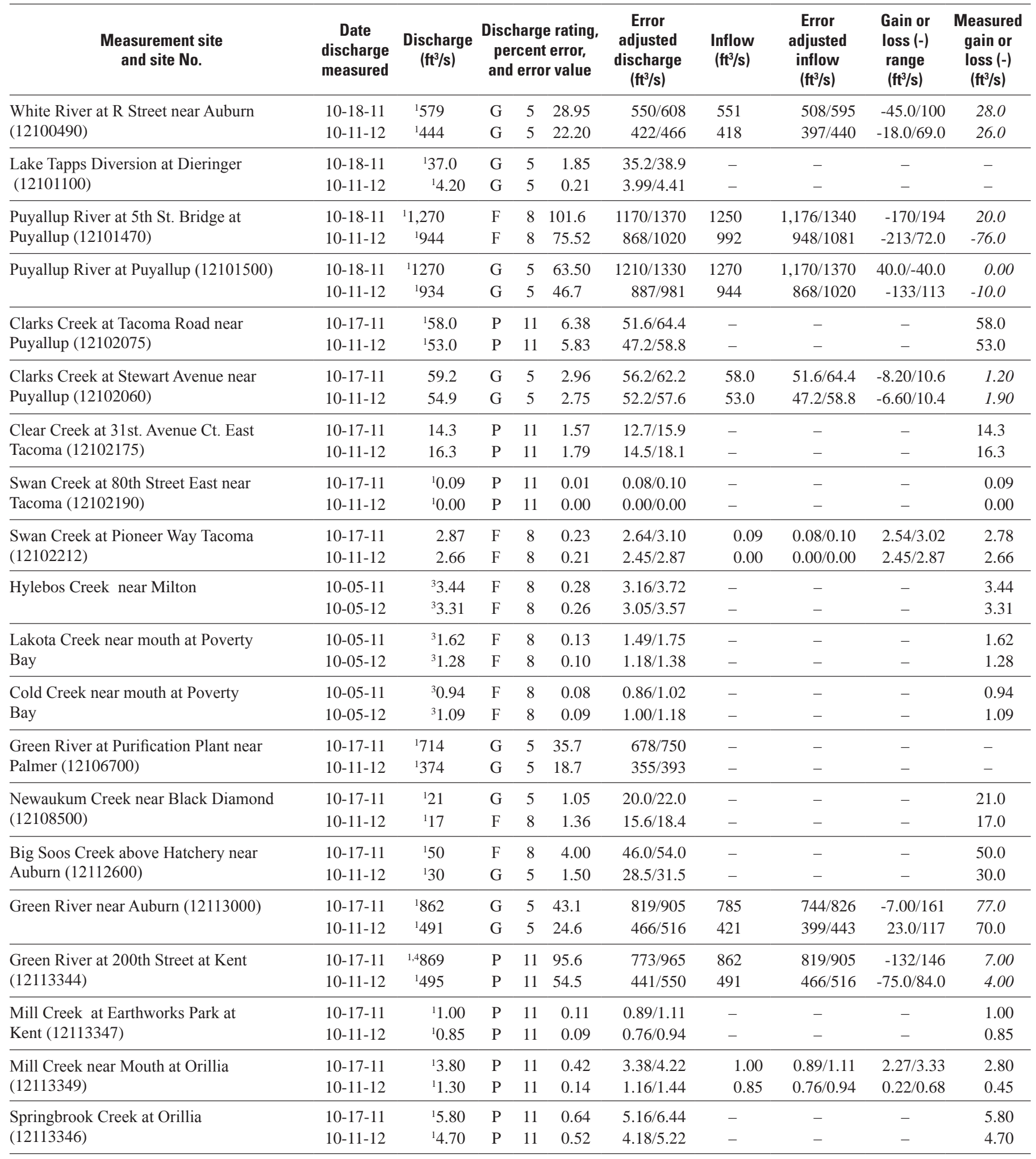

${ }^{1}$ Daily mean streamflow at U.S. Geological Survey streamflow-gaging station.

${ }^{2}$ Discharge used in gain/loss computation is the sum of White River above Boise Creek (12099200) and White River Flume at Buckley (12098920).

${ }^{3}$ Discharge measurement by Robinson Noble, Inc. (Burt Clothier, written commun., 2014).

${ }^{4}$ Estimated by U.S. Geological Survey based on discharge measurements from nearby sites. 
Table 6. Estimated groundwater withdrawals from wells in 2012, Puyallup River Watershed, Washington.

\begin{tabular}{lc}
\hline \multicolumn{1}{c}{ Type of well } & $\begin{array}{c}\text { Withdrawal } \\
\text { (acre-feet) }\end{array}$ \\
\hline Group A public water-supply & 27,500 \\
Group B public water-supply & 800 \\
Self-supplied domestic & 1,500 \\
Other self-supplied & 6,800 \\
Irrigation of agricultural crops and pastures & 6,000 \\
& 42,600 \\
\hline
\end{tabular}

Groundwater discharge occurs at numerous springs in the study area. Locations for 245 springs, and discharge at 119 locations have been previously reported in several studies (Blair, 1929; Sceva and others, 1955; Walters and Kimmel, 1968; Luzier, 1969; Jones and others, 1999, Savoca and others, 2010), and records compiled by the Washington State Department of Health (2014), Robinson Noble, Inc. (Burt Clothier, written commun., 2014), and local municipalities and public water systems. The total of all previously reported discharge of springs in the study area is about $111 \mathrm{ft}^{3} / \mathrm{s}$ (80,300 acre-ft/yr). Spring discharge values compiled from previous studies span a 77-year period from 1937 to 2013.
Spring discharge has varied considerably during this period at many locations, and discharge has ceased at other locations. The most recently reported discharge was used in this compilation for springs with multiple discharge measurements, and springs that no longer flow were excluded. In addition, there are many unmeasured springs and the total discharge of these springs in the study area is unknown.

Groundwater discharge as evaporation and transpiration of shallow groundwater, and as submarine seepage to Puget Sound was not directly measured during this study. Although not directly quantified, evapotranspiration is likely an important component of groundwater discharge along riparian areas and in regions where saturated conditions are close to land surface.

\section{Groundwater and Surface-Water Interactions}

The exchange of water between the groundwater-flow system and streams in the study area was characterized using synoptic streamflow measurements made in October 2011 and October 2012 at 62 stream locations (table 5 and pls. 1 and 4). This information was used to identify stream reaches that gain or lose flow to the groundwater system. Streamflow measurements were made during the low-flow season, usually August-October (fig. 25), to capture baseflow conditions.

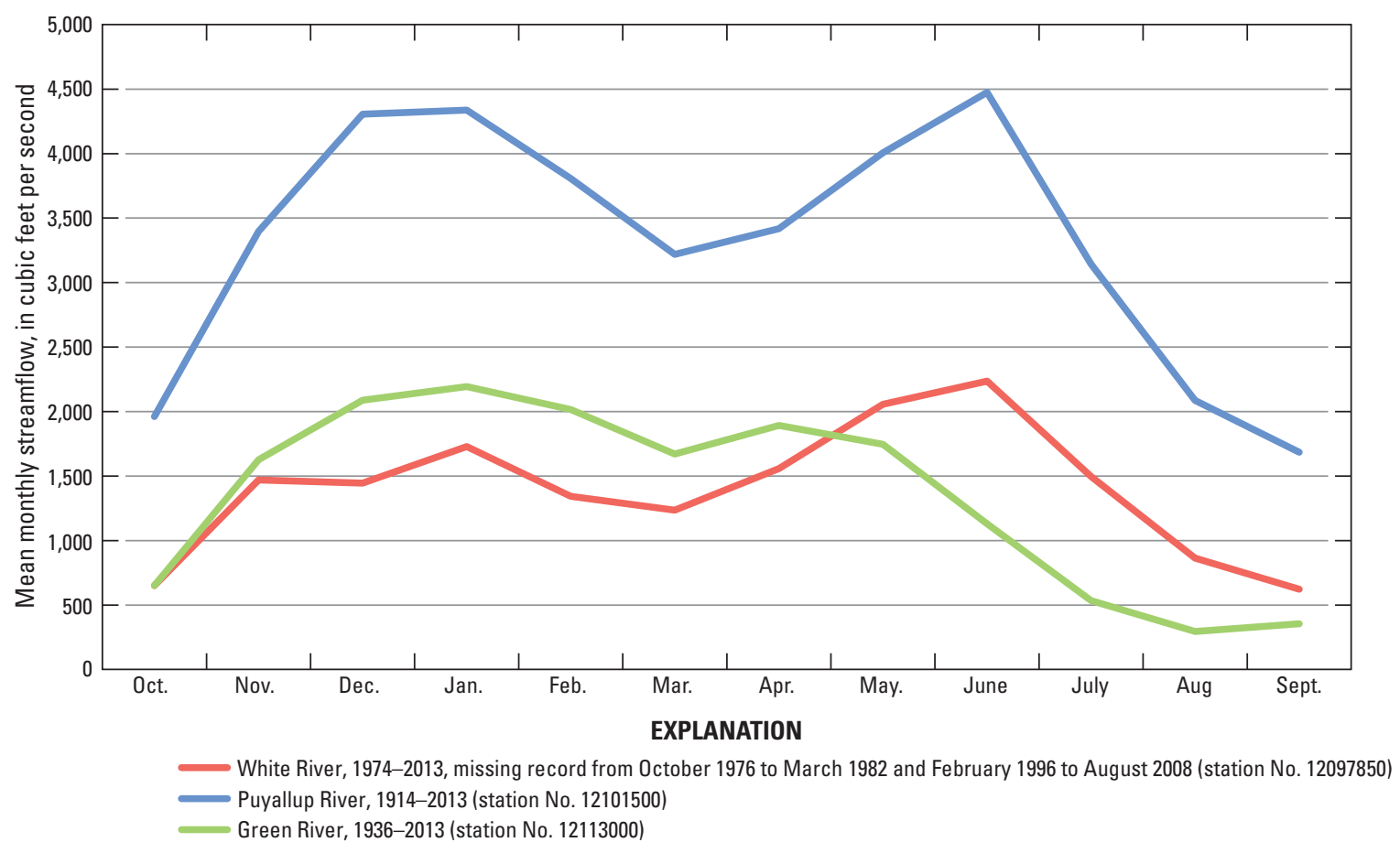

Figure 25. Mean monthly streamflow at U.S. Geological Survey streamflow-gaging stations for the Puyallup, White, and Green Rivers, Puyallup River Watershed and vicinity, Washington. 
Perennial streams in the study area receive flow from melting snow and glacial ice in addition to baseflow and overland flow. Diurnal variations in streamflow, from melting snow and glacial ice may introduce uncertainty into gaining and losing reach calculations. Therefore, streamflows were measured during a period of cool and dry conditions (October 2011 and October 2012) when the effects of large diurnal variation in streamflow would be the lowest (figs. 26 and 27).

The results of the synoptic streamflow measurements are shown in table 5. Most streamflow measurements were rated "good" or "fair"; however, 18 measurements were rated "poor" because of suboptimal flow conditions (low velocity, shallow water depth, or the presence of aquatic vegetation) or the need to estimate the streamflow value. Inflow (table 5) is the sum of streamflows measured upstream of the measurement site and is used to compute the difference between streamflow upstream of the site and at the site. The sign of the difference in streamflow (positive or negative value) indicates a gaining or losing stream reach, respectively. Uncertainties as a result of measurement error were too large at some locations to make defensible conclusions regarding the characterization of gaining or losing stream reaches and those values are italicized in table 5. For example, the October 2011 error adjusted minimum and maximum inflow values to Puyallup River at Orting (12093510), 270 and $298 \mathrm{ft}^{3} / \mathrm{s}$, respectively, and minimum and maximum discharge at Puyallup River at Orting (12093510), 261 and $289 \mathrm{ft}^{3} / \mathrm{s}$, respectively; result in a gain or loss uncertainty range (cumulative measurement error) of -37.0 to $19.0 \mathrm{ft}^{3} / \mathrm{s}$. The uncertainty range suggests the possibility of either a gaining or losing stream reach (near-neutral conditions) and does not support the characterization of a losing reach indicated by the unadjusted value (measured loss) of $-9.00 \mathrm{ft}^{3} / \mathrm{s}$. Conclusions regarding the characterization of gaining or losing stream reaches were able to be made for measurements at many locations (table 5). For example, the October 2012 error adjusted minimum and maximum values for inflow to the Puyallup River at Orting (12093510), 257 and $284 \mathrm{ft}^{3} / \mathrm{s}$, respectively, and flow at Puyallup River at Orting (12093510), 225 and $249 \mathrm{ft}^{3} / \mathrm{s}$, respectively, result in a gain or loss uncertainty range (cumulative measurement error) of -59.0 to $-8.00 \mathrm{ft}^{3} / \mathrm{s}$, and supports the characterization of a losing reach indicated by the unadjusted value of $-33.0 \mathrm{ft}^{3} / \mathrm{s}$. Other potential sources of error in the characterization of gaining and losing stream reaches include the transient nature of streamflows and errors associated with the time lag between upstream, and downstream measurements and unaccounted for tributary inflows within stream reaches.

Most stream reaches in the study area either gain flow from groundwater discharge or exhibit near-neutral conditions with no substantial gain or loss of flow. In near-neutral reaches, streamflow gains and losses were measured, but they were smaller in magnitude than the cumulative streamflow-measurement errors (italicized values in table 5).
Gaining conditions were observed in the upper reaches of smaller streams in the study area (such as Voight, South Prairie, Clarks, Hylebos, and Big Soos Creeks), which typically drain upland areas adjacent to major river valleys, and do not receive flow from melting snow or glacial ice during the low-flow season. Near-neutral conditions were observed in the lower reaches of several smaller streams (such as, South Prairie and Huckleberry Creeks, and Clearwater River) upstream of their confluence with major river valleys.

Near-neutral conditions were observed along most reaches of larger streams in the study area (Puyallup, Carbon, White, and Green Rivers) which occupy major river valleys and receive flow from melting snow or glacial ice during the low-flow season. The greater occurrence of near-neutral conditions on larger streams may be due, in part, to the small magnitude of seepage gains and losses relative to the total streamflow. Because streamflow-measurement errors scale with the magnitude of streamflow, larger streamflow measurements have greater associated measurement errors and streamflow gains or losses must be commensurately larger in magnitude to be detectable. Though near-neutral conditions predominate, gaining reaches were detectable at several locations on larger streams including the Puyallup (12093500), Carbon (12094300, 12093610), Greenwater (12097500), White (12097850, 12099200), and Green (12113000) Rivers. A losing reach was detectable at one location on the Puyallup River (12093510).

\section{Groundwater-Level Fluctuations}

Groundwater levels fluctuate over time, both seasonally and long term (annually), in response to changing rates of groundwater recharge and discharge. When recharge exceeds discharge, the amount of water stored in an aquifer increases and water levels rise; when discharge exceeds recharge, groundwater storage decreases and water levels decline. Groundwater levels also may respond to changes in nearby stream stage. When stream stage (altitude of the water surface) exceeds nearby groundwater levels, streamflow may recharge the aquifer, causing a rise in groundwater levels; when groundwater levels exceed nearby stream stage, discharge from the aquifer to the stream may occur, resulting in a decline in groundwater levels. Seasonal changes in groundwater levels were observed in many wells in the study area (Lane and others, 2013). These observed changes follow a typical pattern for shallow wells in western Washington. Water levels rose in the autumn and winter when precipitation and river stage were high, and declined during spring and summer when precipitation and river stage were low (figs. 28 and 29). Additionally, and typical for western Washington, the peak groundwater levels lagged behind the peak streamflow by a few months (Simonds and others, 2004; Savoca and others, 2010; Welch and others, 2014), reflecting the storage characteristics of the groundwater system. 


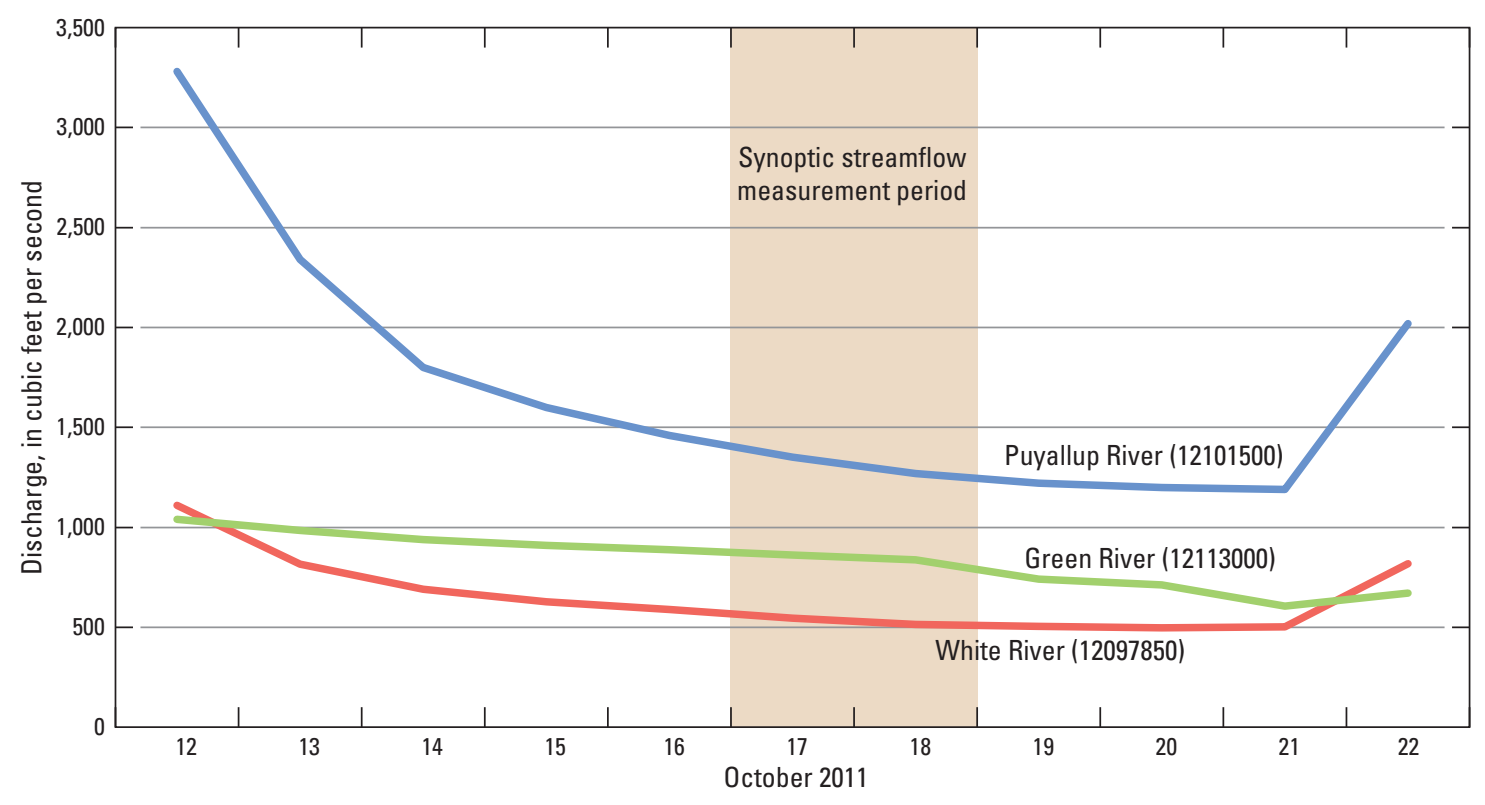

Figure 26. Daily streamflow for U.S. Geological Survey streamflow-gaging stations on the Puyallup, White, and Green Rivers, Puyallup River Watershed and vicinity, Washington, October 12-22, 2011. Site numbers shown in parentheses.

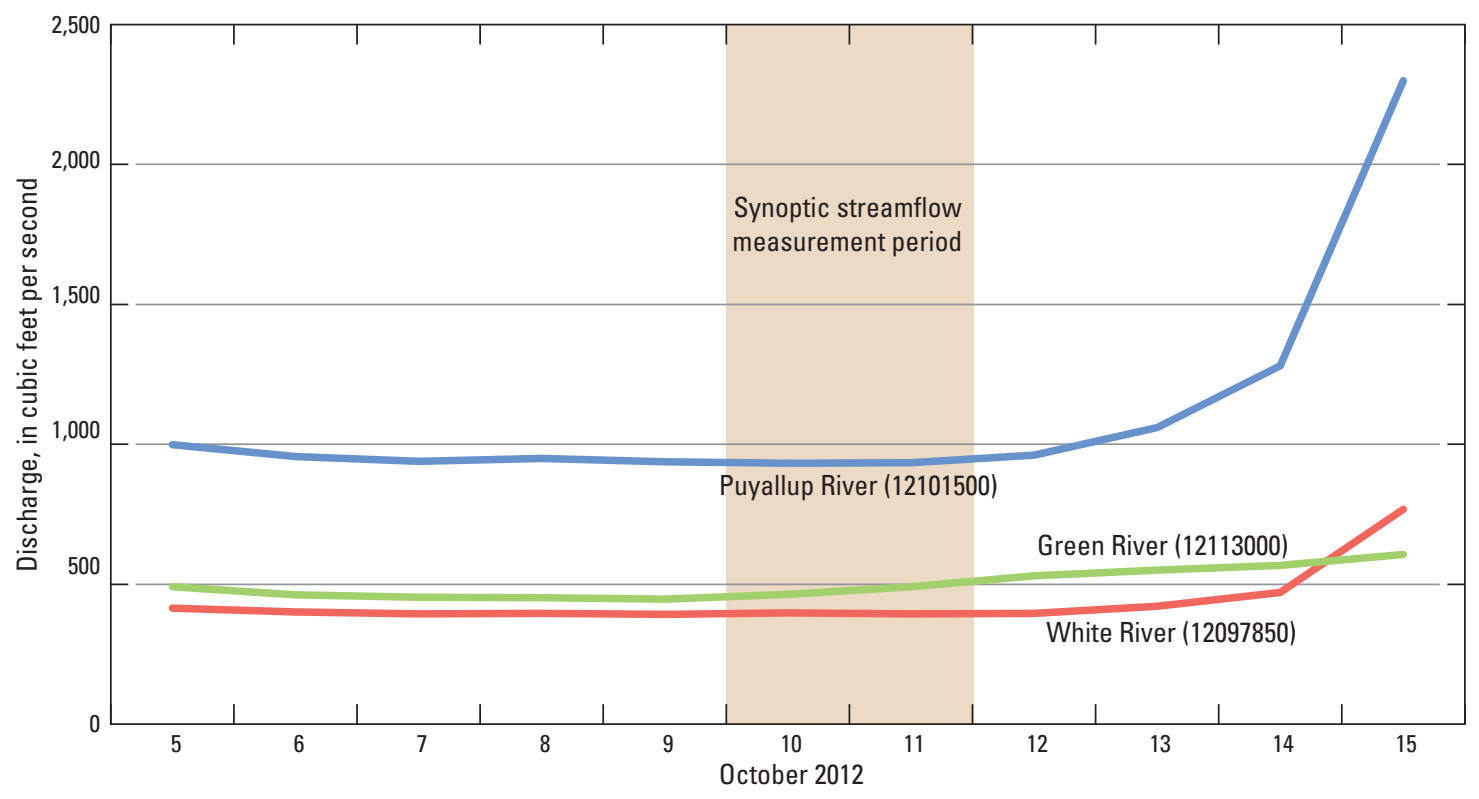

Figure 27. Daily streamflow for U.S. Geological Survey streamflow-gaging stations on the Puyallup, White, and Green Rivers, Puyallup River Watershed and vicinity, Washington, October 5-15, 2012. Site numbers shown in parentheses. 


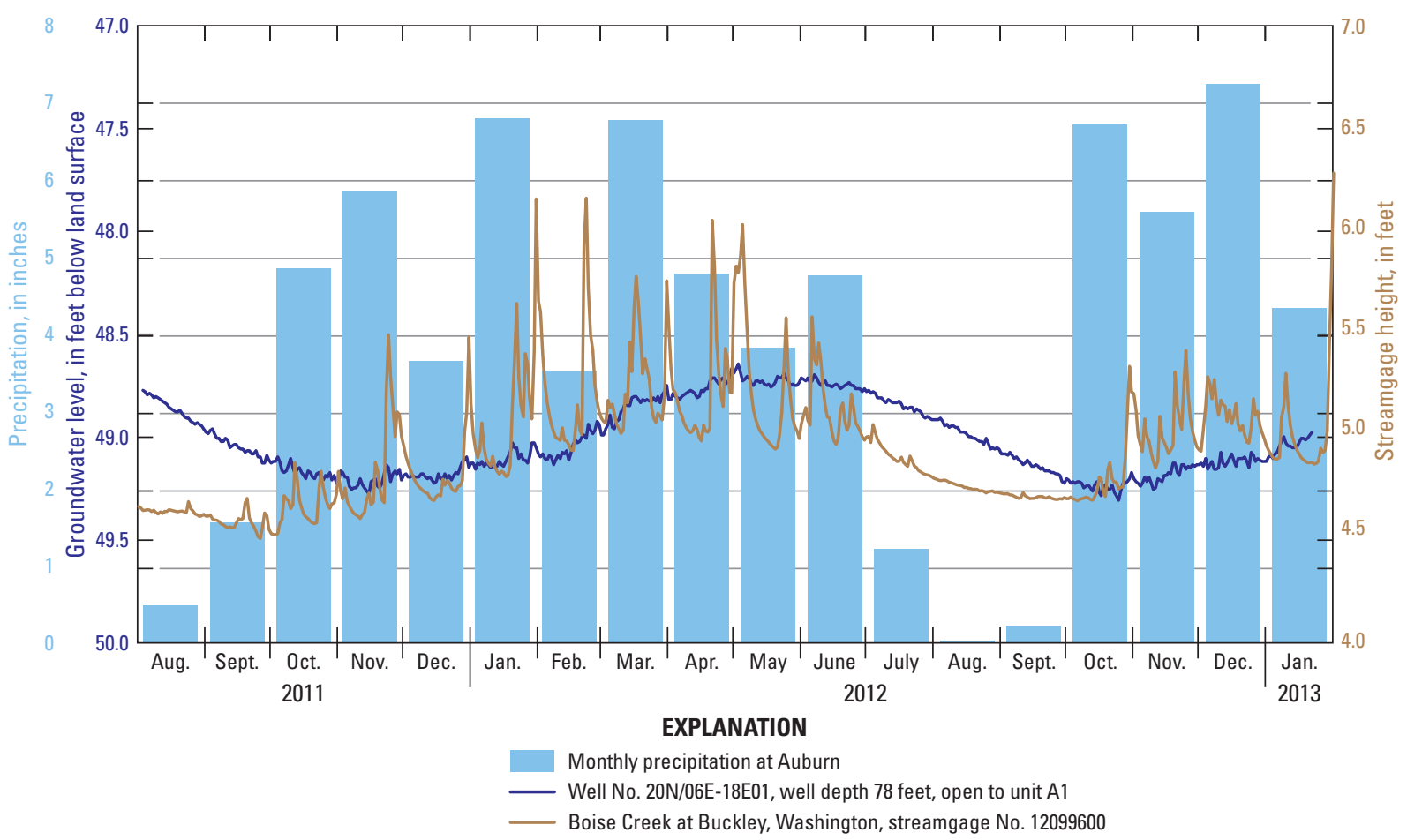

Figure 28. Water levels in well 20N/06E-18E01, stream stage at U.S. Geological Survey streamflowgaging station on Boise Creek, and precipitation at Auburn, Puyallup River Watershed and vicinity, Washington, August 2011-January 2013.

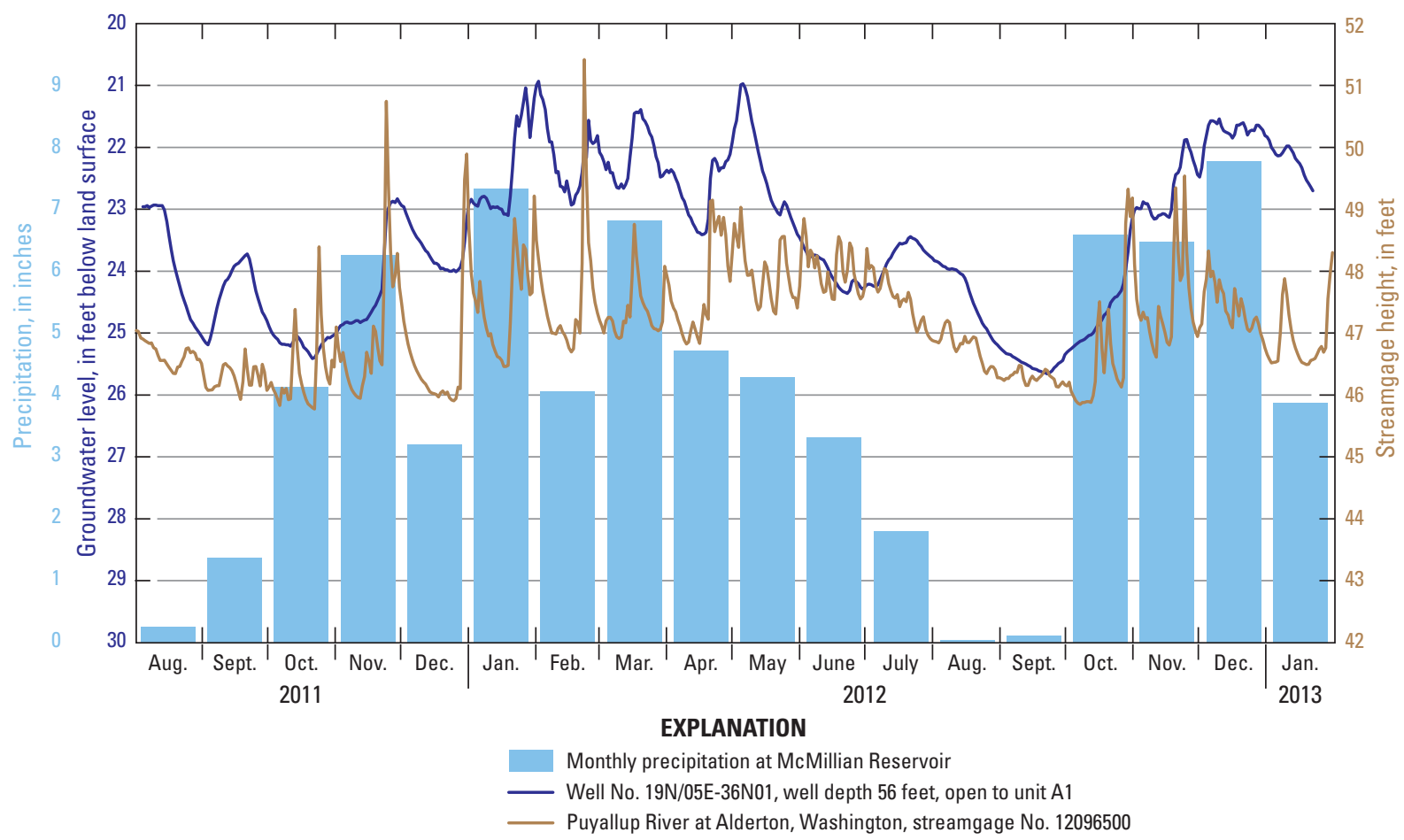

Figure 29. Water levels in well 19N05E-36N01, stream stage at U.S.Geological Survey streamflowgaging station on the Puyallup River, and precipitation at McMillin Reservoir, Puyallup River Watershed and vicinity,Washington, August 2011-January 2013. 
The timing and magnitude of seasonal groundwaterlevel fluctuations in an aquifer system are related to (1) the hydraulic characteristics of aquifer materials and adjacent confining units, (2) the presence of unconfined or confined aquifer conditions, (3) the depth to groundwater, (4) the proximity to perennial surface-water features, and (5) the depth of the well and screened intervals being measured. Water levels in deep wells typically respond more slowly and with less magnitude than water levels in shallow wells because deep wells are farther from the recharge source and variability is dampened. Water levels in wells completed in the unconsolidated hydrogeologic units exhibited seasonal variations ranging from less than 1 to about $32 \mathrm{ft}$ (table 7). Large water-level fluctuations (up to about $26 \mathrm{ft}$ ) during the monitoring period (March 2011-March 2013) were measured in wells completed in the bedrock unit. Large water-level fluctuations in wells completed in the bedrock unit may be attributed to the presence of water-bearing fractures (high conductivity and low storage) within local outcrop areas receiving precipitation recharge, and the relatively low (compared to sands and gravels) storage capacity (primary porosity) of consolidated volcanic and sedimentary units (Freeze and Cherry, 1979; Fetter, 1988).

\section{Water Budget}

On a long-term basis, a hydrologic system usually is in a state of dynamic equilibrium; that is, inflow to the system equals outflow from the system, and there is little or no net change in the amount of water stored within the system. An approximate water budget for an average year of precipitation for the water-budget area was calculated (table 8) during the study period (January 1, 2011-December 31, 2012). The water budget assumes there is little or no net change in the amount of water stored within the system (inflow equals outflow). For this assumption to be correct, there should be an absence of long-term trends in groundwater levels in the study area. However, there is no long-term ambient groundwater monitoring network that covers the entire study area, and data from the short-term (March 2011-March 2013) monthly monitoring network established for this study are insufficient to evaluate water-level trends relating to long-term changes in groundwater storage. The Tacoma-Pierce County Health Department (2007) long-term (1996-2006) groundwater monitoring report identified "possible declining water levels" in 9 of 31 active public-supply wells in the study area.

Table 7. Summary of groundwater-level fluctuations and well depths by hydrogeologic unit, Puyallup River Watershed, Washington, March 2011 through March 2013.

$[-$, no data $]$

\begin{tabular}{|c|c|c|c|c|c|c|c|}
\hline \multirow[t]{2}{*}{ Hydrogeologic unit } & \multirow{2}{*}{$\begin{array}{l}\text { Number } \\
\text { of wells }\end{array}$} & \multicolumn{3}{|c|}{$\begin{array}{l}\text { Water-level fluctuation } \\
\text { (feet) }\end{array}$} & \multicolumn{3}{|c|}{$\begin{array}{c}\text { Well depth } \\
\text { (feet below land surface) }\end{array}$} \\
\hline & & Minimum & Median & Maximum & Minimum & Median & Maximum \\
\hline AL1 upper alluvial valley aquifer & 9 & 2.22 & 4.08 & 10.72 & 15 & 59 & 105 \\
\hline MFL mudflow-lahar confining unit & 5 & 2.41 & 3.68 & 6.26 & 39 & 77 & 135 \\
\hline AL2 lower alluvial valley aquifer & 21 & 2.03 & 3.03 & 14.79 & 33 & 116 & 440 \\
\hline A1 aquifer & 17 & 1.00 & 4.06 & 19.15 & 18 & 78 & 176 \\
\hline A2 confining unit & 11 & 0.13 & 3.93 & 12.85 & 27 & 126 & 224 \\
\hline A3 aquifer & 57 & 1.02 & 4.59 & 25.5 & 50 & 140 & 360 \\
\hline B confining unit & 7 & 0.23 & 1.73 & 6.69 & 154 & 195 & 223 \\
\hline $\mathrm{C}$ aquifer & 33 & 0.87 & 5.04 & 32.45 & 75 & 271 & 436 \\
\hline D confining unit & 4 & 4.39 & 7.80 & 17.8 & 61 & 78 & 136 \\
\hline E aquifer & 6 & 1.82 & 3.82 & 17.83 & 280 & 390 & 518 \\
\hline F confining unit & 0 & - & - & - & - & - & - \\
\hline G undifferentiated deposits & 1 & 2.90 & 2.90 & 2.90 & 900 & 900 & 900 \\
\hline Bedrock unit & 6 & 2.94 & 13.4 & 25.7 & 177 & 348 & 496 \\
\hline
\end{tabular}


Table 8. Estimated annual water budget for Puyallup River Watershed and vicinity, Washington, January 1, 2011 through December 31, 2012

\begin{tabular}{|c|c|c|c|}
\hline \multirow[b]{2}{*}{ Water budget component } & \multicolumn{2}{|c|}{ Quantity } & \multirow[b]{2}{*}{ Percentage } \\
\hline & $\begin{array}{l}\text { Inches } \\
\text { per year }\end{array}$ & $\begin{array}{l}\text { Acre-feet } \\
\text { per year }\end{array}$ & \\
\hline \multicolumn{4}{|l|}{ Precipitation } \\
\hline \multicolumn{4}{|l|}{ Fate of precipitation } \\
\hline ET and Surface runoff & 31 & 847,400 & 59 \\
\hline Groundwater recharge & 21 & 580,600 & 41 \\
\hline Total precipitation & 52 & $1,428,000$ & 100 \\
\hline \multicolumn{4}{|l|}{ Fate of groundwater recharge } \\
\hline Withdrawals from wells & 1.5 & 42,600 & 7 \\
\hline Other natural discharge & 19.5 & 538,000 & 93 \\
\hline Total groundwater recharge & 21 & 580,600 & 100 \\
\hline
\end{tabular}

Declining water levels were not observed in the remaining 22 wells in the network. Similarly, long-term monitoring by Lakehaven Utility District (1980s-present) shows recent (2009-present) increases in water levels, indicating an increase in water storage. These long-term water-level trends, suggests that the conditions for dynamic equilibrium may not be met at some locations in the study area.

The data and methods used to estimate values of precipitation, groundwater recharge, groundwater discharge to streams and springs, and withdrawals from wells are described in previous sections of this report along with descriptions of the uncertainties associated with the estimates of these budget components. These uncertainties arise from the use of timeaveraged approximations of precipitation and groundwater discharge; groundwater withdrawal estimates that do not account for potential return flows; and spring flow estimates that do not account for unreported spring discharges. The water budget is intended to provide an initial estimate of budget components, and because of the above limitations, should be considered an approximation of a complex system.

Evapotranspiration plus surface runoff was computed as the quantity of water remaining after groundwater recharge was subtracted from precipitation. Precipitation during the study period (January 1, 2011-December 31, 2012) averaged an estimated $52 \mathrm{in} / \mathrm{yr}$ in the area. About 41 percent of precipitation enters the groundwater system as recharge of which 7 percent is withdrawn from wells. The rest of the recharge discharges naturally from the groundwater system to rivers, springs, and submarine seepage to Puget Sound, or exits the study area through subsurface flow in the Green River valley. Estimated magnitudes of the components of the natural discharge are highly uncertain, however, baseflow calculated from the average of the October 2011 and October 2012 synoptic streamflow measurements, which represents a near-minimum estimate of annual baseflow, is 314,500 acre-ft/yr (54 percent of the total recharge) suggesting that most recharge discharges to streams in the study area.

\section{Summary and Conclusions}

Groundwater is an important resource for domestic, commercial, and industrial usage in the Puyallup River Watershed (PRW), and groundwater discharge helps maintain late-summer and early-autumn streamflow (baseflow) in many area streams. Consequently, as the population grows, and commercial and industrial activity increase, so does the demand for groundwater. However, the quantity of usable groundwater, the potential effects of future natural conditions and anthropogenic activities on groundwater resources, and the potential effects of groundwater withdrawals on streamflow, are not well understood in some areas of the watershed. Additional information is needed to help ensure the long-term sustainability of the area's groundwater and surface-water resources. This study was conducted to characterize the groundwater-flow system in the PRW and vicinity. A second phase of this project will integrate this and other information into a numerical groundwater-flow model to contribute to an improved understanding of water resources in the PRW.

The study area covers about 1,220 square miles in northern Pierce and southern King Counties, Washington, and extends north to the Green River and Auburn Valleys, southwest to the Puyallup River and adjacent uplands, and is bounded on the south and east by foothills of the Cascade Range and on the west by Puget Sound. The northwest-flowing Puyallup River occupies a large, relatively flat alluvial valley, and, together with its major tributaries (Carbon and White Rivers), drains a broad upland region that covers most of the study area. Tributaries to major rivers in the central part of the study area include Boise, South Prairie, Wilkeson, and Voight Creeks. The Clearwater and Greenwater Rivers, and Huckleberry Creek flow into the White River in the eastern part of the study area, and Swan, Clear, Clarks, 
and Hylebos Creeks join the Puyallup River near its mouth in the western part of the study area. The Green River flows to the west, along the northern margin of the study area, before turning to the north upon entering the Auburn Valley. Perennial streamflow conditions are present in the Puyallup River and its major tributaries, all of which receive flow from melting snow and glacial ice in addition to groundwater discharge and overland flow from precipitation. Intermittent and ephemeral flow conditions are common in many smaller tributary stream reaches, especially during the summer months. Numerous springs are present throughout the study area, and contribute to late-summer baseflow to streams and year-round groundwater discharge to Puget Sound along shoreline bluffs. The area is underlain by a northwest-thickening sequence of unconsolidated glacial (till and outwash) and interglacial (fluvial and lacustrine) deposits which overlie sedimentary and volcanic bedrock units that crop out in the foothills along the southern and eastern margin of the study area.

Geologic units were grouped into 13 hydrogeologic units consisting of aquifers and confining units. A surficial hydrogeologic unit map was constructed and used with well information from 1,012 drillers' logs to produce eight hydrogeologic sections and unit extent and thickness maps. Unconsolidated aquifers (AL1, AL2, A1, A3, C, E, and G) typically consist of moderately to well-sorted alluvial and glacial outwash deposits of sand, gravel, and cobbles, with minor lenses of silt and clay. These units often occur as discontinuous or isolated bodies and are of highly variable thickness. Unconfined conditions occur in areas where aquifer units are at land surface; however, much of the study area is mantled by glacial till, or mudflow-lahar deposits, and confined aquifer conditions are common. Groundwater in unconsolidated glacial and interglacial aquifers generally flows to the northwest towards Puget Sound, and to the north and northeast towards the Puyallup River, White River, and Green River valleys. These generalized flow patterns are complicated by the presence of low permeability confining units and bedrock that separate discontinuous bodies of aquifer material and act as local groundwater-flow barriers.

Water-level differences between the AL1 and AL2 alluvial aquifers indicate the potential for upward groundwater flow where the White and Green Rivers enter the Auburn Valley, and flowing wells at two locations in the AL2 lower alluvial aquifer near the confluence of the Puyallup and Carbon Rivers also suggest an upward vertical gradient. Water-level differences between the A1 and A3 aquifers indicate the potential for downward groundwater flow adjacent to the mountain front, and within upland areas between the White and Green Rivers. Water-level differences between the $\mathrm{A} 3$ and $\mathrm{C}$ aquifers show the potential for downward vertical flow throughout much of the study area, and flowing wells at several locations in units $\mathrm{C}$ and $\mathrm{G}$ in the Puyallup River and Auburn Valleys indicate an upward vertical gradients and groundwater flow.
Unconsolidated confining units (MFL, A2, B, D, and F) typically consist of poorly sorted mudflow-lahar deposits, glacial till,or glaciolacustrine and interglacial deposits of clay, silt, sand, gravel, cobbles, and boulders. Locally occurring sand and gravel lenses capable of providing water for domestic use can be found in these units but are infrequent and discontinuous. Water levels in wells completed in the unconsolidated hydrogeologic units exhibited seasonal variations ranging from less than 1 to about 32 feet. Unconsolidated aquifer and confining units are underlain by Tertiary bedrock units primarily consisting of sedimentary claystone, siltstone, sandstone, beds of coal, and volcanic rocks. These units, described as the basement confining unit by Jones (1999), are not considered part of the active groundwater-flow system.

Synoptic streamflow measurements made in October 2011 and October 2012 indicate a total groundwater discharge to streams in the water-budget area (520 square miles located within the larger study area) of 340,990 and 271,490 acre-feet per year, respectively. Most stream reaches in the study area either gain flow from groundwater discharge or exhibit near-neutral conditions with no substantial gain or loss of flow. Groundwater discharge occurs at numerous springs in the area and the total previously reported discharge of springs in the area is approximately 80,300 acre-feet per year.

The water-budget area received about 1,428,000 acrefeet or about 52 inches of precipitation per year (January 1, 2011-December 31, 2012). About 41 percent of precipitation enters the groundwater system as recharge. Seven percent of this recharge is withdrawn from wells while at least one-half of this recharge discharges to rivers. The remaining groundwater recharge leaves the groundwater system as discharge to springs, submarine discharge, seepage to Puget Sound, or exits the study area through subsurface flow in the Green River valley.

\section{Acknowledgments}

The authors wish to thank the many well owners in the study area who provided access to their wells. The authors also acknowledge the assistance and information provided by public water-supply systems, water districts, and state, local, and tribal stake holders; these include Cascade Water Alliance, Lakehaven Utility District, Summit Water \& Supply Company, Mt. ViewEdgewood Water Company, the cities of Tacoma, Auburn, Puyallup, Sumner, Milton, Enumclaw, Bonney Lake, and Fife, the Muckleshoot Indian Tribe, the Puyallup Tribe of Indians, the Washington State Department of Health, The Russell Family Foundation, and the Puyallup River Watershed Council. Information used to characterize the groundwater-flow system was generously provided by Robinson Noble, Inc., Carr and Associates Inc., Keta Waters LLC, Associated Earth Sciences Inc., and RH2 Engineering, Inc. 


\section{References Cited}

Bear, Jacob, 1979, Hydraulics of groundwater: New York, McGraw-Hill, 569 p.

Bidlake, W.R., and Payne, K.L., 2001, Estimating recharge to ground water from precipitation at Naval Submarine Base Bangor and vicinity, Kitsap County, Washington: U.S. Geological Survey Water-Resources Investigations Report 01-4110, $33 \mathrm{p}$.

Blair, H.O., 1929, Underground water resources in the vicinity of Tacoma: Journal of the American Water Works Association, v. 21, no. 9, p. 1185-1195.

Brown and Caldwell, 1985, Clover/Chambers Creek geohydrologic study for Tacoma-Pierce County Health Department: Seattle, Washington, Brown and Caldwell, unpaginated.

Booth, D.B., and Waldron, H.H., 2004, Geologic map of the Des Moines 7.5' quadrangle, King County, Washington: U.S. Geological Survey Scientific Investigations Map 2855, scale 1:24,000.

Booth, D.B., Waldron, H.H., and Troost, K.G., 2004, Geologic map of the Poverty Bay 7.5' quadrangle, King and Pierce Counties, Washington: U.S. Geological Survey Scientific Investigations Map 2854, scale 1:24,000.

Cakir, R., and Walsh, T.J., 2014, Loss estimation pilot project for lahar hazards from Mount Rainier, Washington: Washington State Department of Natural Resources, Information Circular 113, 17 p.

Carnahan, B., Luther, H.A., and Wilkes, J.O., 1969, Applied numerical methods: New York, John Wiley and Sons, Inc., $604 \mathrm{p}$.

Carr and Associates Inc., 1988, Report on the 1987-88 test drilling program for the City of Tacoma: Tacoma, Washington, Carr and Associates Inc., unpaginated.

Daly, Christopher, Neilson, R.P., and Phillips, D.L., 1994, A statistical-topographic model for mapping climatological precipitation over mountainous terrain: Journal of Applied Meteorology, v. 33, no. 2, p. 140-158.

Dragovich, J.D., Pringle, P.T., and Walsh, T.J., 1994, Extent and geometry of the Mid-Holocene Osceola Mudflow in the Puget Lowland-Implications for Holocene sedimentation and paleogeography: Washington State Department of Natural Resources, Washington Geology, v. 22, no. 3, p. 3-26.
Drost, B.W., Ely, D.M., and Lum II, W.E., 1999, Conceptual model and numerical simulation of the ground-water-flow system in the unconsolidated sediments of Thurston County, Washington: U.S. Geological Survey Water-Resources Investigations Report 99-4165, $254 \mathrm{p}$. [Also available at http://pubs.usgs.gov/wri/wri994165/.]

Eckhardt, K., 2005, How to construct recursive digital filters for baseflow separation: Journal of Hydrological Processes, v. 19 , issue 2, p. 507-515.

Ferris, J.G., Knowles, D.B., Brown, R.H., and Stallman, R.W., 1962, Theory of aquifer tests: U.S. Geological Survey Water-Supply Paper 1536-E, 174 p. [Also available at http:// pubs.usgs.gov/wsp/wsp1536-E/.]

Fetter, C.W., 1988, Applied Hydrogeology: Columbus, Ohio, Merrill Publishing Company, 592 p.

Freeze, R.A., and Cherry, J.A., 1979, Groundwater: Englewood Cliffs, N.J., Prentice-Hall, 604 p.

Hutchinson, M.F., 1989, A new method for gridding elevation and streamline data with automatic removal of pits: Journal of Hydrology, v. 106, p. 211-232.

Jin, S., Yang, L., Danielson, P., Homer, C., Fry, J., and Xian, G., 2013, A comprehensive change detection method for updating the National Land Cover Database to circa 2011: Remote Sensing of Environment, v. 132, p. 159-175.

Johnson, K.H., Savoca, M.E., and Clothier, Burt, 2011, Numerical simulation of the groundwater-flow system in the Chambers-Clover Creek Watershed and vicinity, Pierce County, Washington: U.S. Geological Survey Scientific Investigations Report 2011-5086, 108 p.

Jones, M.A., 1996, Thickness of unconsolidated deposits of the Puget Sound aquifer system, Washington and British Columbia: U.S. Geological Survey Water Resources Investigations Report 94-4133, 1 pl., scale 1:500,000.

Jones, M.A., 1999, Geologic framework for the Puget Sound aquifer system, Washington and British Columbia: U.S. Geological Survey Professional Paper 1424-C, 31 p., 18 pls., scales 1:500,000 and 1:100,000. [Also available at http://pubs.er.usgs.gov/usgspubs/pp/pp1424C.]

Jones, M.A., Orr, L.A., Ebbert, J.C., and Sumioka, S.S., 1999, Ground-water hydrology of the Tacoma-Puyallup area, Pierce County, Washington: U.S. Geological Survey WaterResources Investigations Report 99-4013, 154 p.

Kozar, M.D., and Kahle, S.C., 2013, Quality-assurance plan for groundwater activities, U.S. Geological Survey, Washington Water Science Center: U.S. Geological Survey Open-File Report 2013-1151, 88 p. 
Lane, R.C., and Welch, W.B., 2015, Estimated freshwater withdrawals in Washington, 2010: U.S. Geological Survey Scientific Investigations Report 2015-5037, 48 p., http:// dx.doi.org/10.3133/sir20155037.

Lane, R.C., Julich, R.J., and Justin, G.B., 2013, Hydrographs showing groundwater levels for selected wells in the Puyallup River watershed and vicinity, Pierce and King Counties, Washington (ver. 1.1, August 2014): U.S. Geological Survey Data Series 791, http://pubs.usgs.gov/ ds/791/.

Lim, K.J., Engel, B.A., Tang, Zhenxu, Choi, Joongdae, Kim, Ki-Sung, Muthukrishnan, Suresh, and Tripathy, Dibyajyoti, 2005, Automated web GIS based hydrograph analysis tool, WHAT: Journal of the American Water Resources Association, v. 41, no. 6, p. 1407-1416.

Lyne, V.D., and Hollick, M., 1979, Stochastic time-variable rainfall-runoff modeling: Proceedings of the Hydrology and Water Resources Symposium, Perth, 10-12 September, Institution of Engineers National Conference Publication, No. 79/10, p. 89-92.

Luzier, J.E., 1969, Geology and ground-water resources of southwestern King County, Washington: Washington State Department of Water Resources Water-Supply Bulletin no. 28, 260 p.

National Oceanic and Atmospheric Administration, 2013, 1981-2010 climate normal: National Oceanic and Atmospheric Administration, National Climate Data Center database, accessed March 25, 2013, at http://www1.ncdc. noaa.gov/pub/data/normals/1981-2010/.

PRISM Climate Group, 2014, 30-year normals data: PRISM Climate Group data, Oregon State University, accessed July 21, 2014, at http://www.prism.oregonstate.edu/ normals/.

Rantz, S.E., and others, 1982, Measurement and computation of streamflow, volume 1-Measurement of stage and discharge: U.S. Geological Survey Water-Supply Paper 2175, 284 p. [Also available at http://pubs.usgs.gov/wsp/ wsp2175.]

Robinson \& Noble, Inc., and others, 2003, Chambers-Clover technical assessment-Final report: Tacoma, Washington.

Savoca, M.E., Welch, W.B., Johnson, K.H., Lane, R.C., Clothier, B.G., and Fasser, E.T., 2010, Hydrogeologic framework, groundwater movement, and water budget in the Chambers-Clover Creek Watershed and vicinity, Pierce County, Washington: U.S. Geological Survey Scientific Investigations Report 2010-5055, 46 p.
Sceva, J.E., Wegner, D.E., and others, 1955, Records of wells and springs, water levels, and quality of ground water in central Pierce County, Washington: U.S. Geological Survey Open-File Report 55-160, 261 p.

Schasse, H.W., compiler, 1987, Geologic map of the Centralia quadrangle, Washington: Washington Division of Geology and Earth Resources Open File Report 87-11, 28 p., 1 pl., scale $1: 100,000$.

Scott, K.M., and Vallance, J.W., 1995, Debris flow, debris avalanche, and flood hazards at and downstream from Mount Rainier, Washington: U.S. Geological Survey Hydrologic Investigations Atlas HA-729, 9 p., 2 sheets, scale 1:100,000. [Also available at http://vulcan.wr.usgs. gov/Volcanoes/Rainier/Publications/HA-729/framework. html.]

Sinclair, K.A., and Pitz, C.F., 1999, Estimated base-flow characteristics of selected Washington rivers and streams: Washington State Department of Ecology Water Supply Bulletin No. 60 (pub. No. 99-327), 24 p.

Simonds, F.W., Longpré, C.I., and Justin, G.B., 2004, Groundwater system in the Chimacum Creek Basin and surface-water/groundwater interaction in Chimacum and Tarboo Creeks and the Big and Little Quilcene Rivers, Eastern Jefferson County, Washington: U.S. Geological Survey Scientific Investigations Report 2004-5058, 49 p.

Sloto, R.A., and Crouse, M.Y., 1996, HYSEP-A computer program for streamflow hydrograph separation and analysis: U.S. Geological Survey Water-Resources Investigations Report 96-4040, 46 p.

Tabor, R.W., Frizzell, V.A., Booth, D.B., and Waitt, R.B., 2000, Geologic map of the Snoqualmie Pass $30 \times 60$ minute quadrangle, Washington: U.S. Geological Survey Geologic Investigations Series Map I-2538, scale 1:100,000.

Tacoma-Pierce County Health Department, 2007, Long-term groundwater monitoring program:: Tacoma-Pierce County Health Department web page, accessed August 2014, http:// www.tpchd.org/environment/groundwater/long-termgroundwater-monitoring-program/.

Turney, G.L., Kahle, S.C., and Dion, N.P., 1995, Geohydrology and ground-water quality of east King County, Washington: U.S. Geological Survey WaterResources Investigations Report 94-4082, 123 p. [Also available at http://pubs.er.usgs.gov/usgspubs/wri/ wri944082.]

Vaccaro, J.J., Hansen, A.J., and Jones, M.S., 1998, Hydrogeologic framework for the Puget Sound aquifer system, Washington and British Columbia: U.S. Geological Survey Professional Paper 1424-D, 77 p. [Also available at http://pubs.er.usgs.gov/usgspubs/pp/pp1424D.] 
van Heeswijk, Marijke, and Smith, D.T., 2002, Simulation of the ground-water flow system at Naval Submarine Base Bangor and vicinity, Kitsap County, Washington: U.S. Geological Survey Water-Resources Investigations Report 02-4261, 142 p. [Also available at http://pubs.usgs.gov/wri/ wri024261/.]

Walsh, T.J., 1987, Geologic map of the south half of the Tacoma quadrangle, Washington: Washington Division of Geology and Earth Resources Open File Report 87-3, 10 p., 1 pl., scale 1:100,000.

Walters, K.L., and Kimmel, G.E., 1968, Ground-water occurrence and stratigraphy of unconsolidated deposits, central Pierce County, Washington: Washington State Department of Water Resources Water-Supply Bulletin no. 22, 428 p.

Washington State Department of Agriculture, 2014, Agricultural land use data: Washington State Department of Agriculture geodatabase, accessed June 2014, at http://agr. wa.gov/pestfert/natresources/aglanduse.aspx.

Washington State Department of Health, 2014, Public water system data: Office of Drinking Water database, accessed March 2014, at https://fortress.wa.gov/doh/eh/portal/odw/si/ Intro.aspx.
Washington State Office of Financial Management, 2014, Census geographic files - Census 2010 data: Office of Financial Management database, accessed May 2014, at http://www.ofm.wa.gov/pop/geographic/tiger.asp.

Welch, W.B., Frans, L.M., and Olsen, T.D., 2014, Hydrogeologic framework, groundwater movement, and water budget of the Kitsap Peninsula, westcentral Washington: U.S. Geological Survey Scientific Investigations Report 2014-5106, 44 p., http://dx.doi. org/10.3133/sir20145106.

Western Regional Climate Center, 2014a, Daily data (graph and lister) for station 456898: Western Regional Climate Center database, accessed July 2014, at http://www.wrcc. dri.edu/cgi-bin/cliMAIN.pl?wa6898.

Western Regional Climate Center, 2014b Snowdepth (Daily Average) for Station 456898: Western Regional Climate Center database accessed July 2014, at http://www.wrcc.dri. edu/cgi-bin/cliMAIN.pl?wa6898.

Woodward, D.G., Packard, F.A., Dion, N.P., and Sumioka, S.S., 1995, Occurrence and quality of groundwater in southwestern King County, Washington: U.S. Geological Survey Water-Resources Investigations Report 92-4098, $69 \mathrm{p}$. 


\section{Appendix A. Wells in the Puyallup River Watershed and Vicinity, Pierce and King Counties, Washington}

Appendix file is available for download at http://pubs.usgs.gov/sir/2015/5068. 

Publishing support provided by the U.S. Geological Survey

Science Publishing Network, Tacoma Publishing Service Center

For more information concerning the research in this report, contact the Director, Washington Water Science Center

U.S. Geological Survey

934 Broadway, Suite 300

Tacoma, Washington 98402

http://wa.water.usgs.gov 


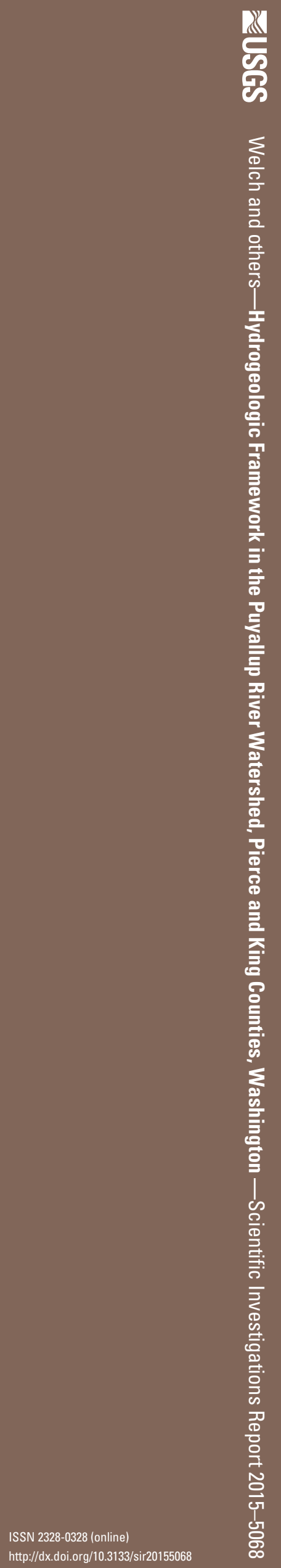

